\begin{abstract}
UNIVERSIDADE DE SÃO PAULO
FACULDADE DE FILOSOFIA, LETRAS E CIÊNCIAS HUMANAS DEPARTAMENTO DE LETRAS ESTRANGEIRAS MODERNAS PROGRAMA DE PÓS-GRADUAÇÃO EM LÍNGUA E LITERATURA ITALIANA
\end{abstract}

MARIA CÉLIA MARTIRANI BERNARDI FANTIN

A arte de narrar em Alessandro Baricco: à procura do velho narrador

que habita em cada um de nós

São Paulo

2008 


\begin{abstract}
UNIVERSIDADE DE SÃO PAULO
FACULDADE DE FILOSOFIA, LETRAS E CIÊNCIAS HUMANAS DEPARTAMENTO DE LETRAS ESTRANGEIRAS MODERNAS PROGRAMA DE PÓS-GRADUAÇÃO EM LÍNGUA E LITERATURA ITALIANA
\end{abstract}

\title{
A arte de narrar em Alessandro Baricco: à procura do velho narrador que habita em cada um de nós
}

Maria Célia Martirani Bernardi Fantin

\author{
Dissertação apresentada ao \\ Programa de Pós-Graduação em \\ Língua e Literatura Italiana do \\ Departamento de Letras \\ Estrangeiras Modernas da \\ Faculdade de Filosofia, Letras e \\ Ciências Humanas da \\ Universidade de São Paulo, para a \\ obtenção do título de Mestre em \\ Letras.
}

Orientador: Profa. Dra.Doris Nátia Cavallari

São Paulo 2008 


\title{
RESUMO:
}

Alessandro Baricco, escritor italiano contemporâneo, acredita na força da narrativa como forma de resistência aos apelos de uma sociedade que já não consegue trocar experiências, nem ver o essencial, já que vítima de uma espécie de embotamento da palavra e dos sentidos, o que, no limite, está intimamente relacionado ao atual crescente processo de desumanização.

Neste estudo procuraremos verificar com que procedimentos o autor investe na reinvenção do narrador, em particular nas obras Novecento e Castelli di rabbia, a fim de revitalizar a arte de narrar.

palavras-chave: Alessandro Baricco, narrador, sociedade contemporânea, liberdade, resistência

\begin{abstract}
:
Alessandro Baricco, a contemporary italian writer, believes in the narrative's strenght as a resistence's form against the claims of a society which is not able to change experiences neither see the essential, because became victim of a word's and senses's lacking. This kind of situation could be deeply related with this growing inhuman process.

In this research we are going to analyze the Baricco's procedures, mainly in Novecento and in Castelli di rabbia, with his purpose to rescue the narrative of the art.
\end{abstract}

key-words: Alessandro Baricco, narrator, contemporary society, freedom, resistence

\section{RIASSUNTO:}

Alessandro Baricco, scrittore italiano contemporaneo crede nella forza della narrativa come modo di resistere ai richiami di una società che non sa più scambiare sperienze, neanche vedere quello che è essenziale, giacchè vittima della mancanza di parole e di sensi, ciò che oggi giorno viene intimamente legato alla crescita del processo di disumanizzazione.

In questa ricerca vorremmo verificare con quali procedimenti l'autore investe nella reinvenzione del narratore, sopratutto nelle opere Novecento e Castelli di rabbia, con lo scopo di rivitalizzare l'arte di narrare.

parole-chiavi: Alessandro Baricco, narratore, società contemporanea, libertà, resistenza 
A meu pai Floriano e à tia Flora, meus eternos anjos da guarda... 


\section{SUMÁRIO}

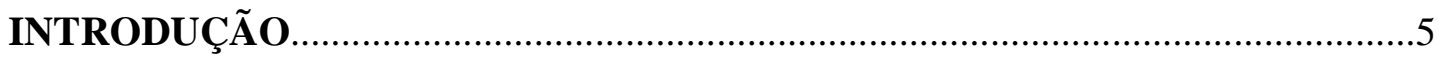

\section{$1^{\circ}$ CAPÍTULO:A DESUMANIZAÇÃO DA SOCIEDADE CONTEMPORÂNEA}

1.1. O crescente processo de desumanização da sociedade contemporânea

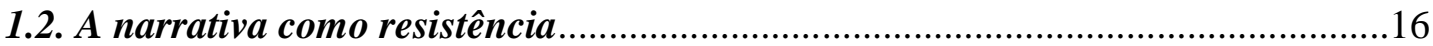

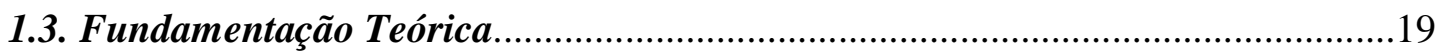

\section{$2^{\circ}$ CAPÍTULO:NOVECENTO:A MÚSICA INFINITA QUE VEM DO MAR}

2.1.Novecento: A música infinita que vem do mar.

2.2. Entendendo o jogo: um menino sem limites e um peixe atrevidamente vermelho

2.3. O jogo da música: aprendendo a dançar

O jogo transparente dos vidros: espelhos da alma.

2.4. O inquietante jogo do olhar: uma grande viagem

\section{$3^{\circ}$ CAPÍTULO:CASTELLI DI RABBIA:NARRAR PARA RESISTIR}

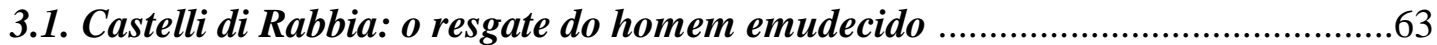

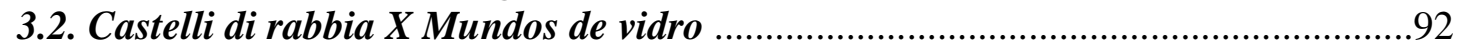

3.3. As máximas de vida: o narrador como conselheiro ...........................................113

4.CONCLUSÃO

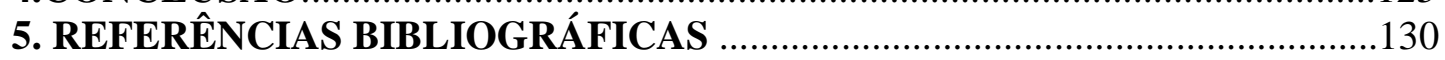

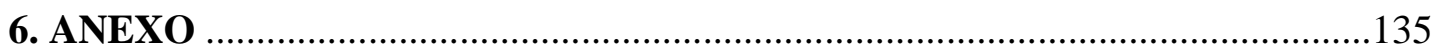

Adotaremos algumas abreviações para os romances analisados ou referenciados, a fim de tornar mais claras as referências. Assim, para as seguintes obras de Baricco: Novecento (NV), Castelli di Rabbia (CR), Oceano Mare (OM) e para o conto de Dino Buzzati, La Libertà (LB). 


\section{INTRODUÇÃO}

A idéia de estudar um autor como Alessandro Baricco surgiu, antes de tudo, quando em uma viagem de estudos, no final do ano de 1999 à Itália, vim, por acaso, a ter, em mãos, a obra Novecento. Por razões muito subjetivas, que nem saberia, racionalmente, explicar, naquele momento, senti o impacto de ter-me tornado uma leitora "capturada". A complexidade, as contradições, a caracterização daquele personagem tão estranho, sensível, assim tão alijado do mundo real, e, ao mesmo tempo, essencialmente verdadeiro, mereciam atenção. A história, meio mágica, meio fantástica, que parecia sair da caixinha da infância do "Era uma vez...", contava a lenda de um menino, que nascera num navio, ali permanecera toda sua vida, tornando-se um grande pianista e que, ao final, por opção, decidira não descer das escadas daquele espaço móvel, flutuante que, em realidade, passara a representar como que seu habitat natural.

Claro que, escritor muito consciente de seu fazer literário, Baricco sabe jogar com o ato de contar histórias e investe, de modo intenso e apaixonado na posição estratégica que faz assumirem os narradores, em toda sua obra ficcional. Então, embora estejamos, como leitores, totalmente entregues ao encantamento da enunciação, ao mesmo tempo, somos lembrados pelo narrador que o que importa é permanecer na viagem, no faz de conta. Ele faz questão de avisar, usando as palavras do próprio Novecento: "Non sei fregato veramente finché hai da parte una buona storia, e qualcuno a cui raccontarla.”(BARICCO, 2004, p. 17), ou seja, o que importa, no fundo, antes de tudo, é ter uma boa história e alguém a quem contá-la. É isso o que importa. É como se fossemos dissuadidos, pelo narrador, a compartilhar do que ele conta, numa cumplicidade, cuja pretensão é a de ressuscitar o prazer do texto, que, conforme verificaremos no desenvolvimento desta pesquisa, atualiza, em boa medida, o prazer de "ouvir" histórias, ao redor do fogo das narrativas orais.

Sobre esta "credulidade" do leitor, apenas mencionaremos, neste momento (para devido aprofundamento, a posteriori) o interessante estudo de Calvino : I livelli della realtà in letteratura. Neste ensaio, um dos aspectos tratados é o da credulidade especial do texto literário, uma "credulidade entre parênteses", que faz com que o leitor assuma um tipo de comportamento, definido por Coleridge, como "suspension of disbelief", 
suspensão da incredulidade (CALVINO, 2002, p.374). E aqui, não há como não perceber que o autor Alessandro Baricco sabe da importância de "capturar" o leitor, fazendo com que ele assuma, ainda que de modo imperceptível, quase inconsciente, o pacto de entrar no jogo, pelo simples prazer de jogar.

Então, já leitora participante e cúmplice daquela espécie de "credulidade entre parênteses", pouco me importava saber se Novecento teria existido ou não, se tudo não seria apenas ficção dentro da ficção, num universo alegórico e intocável. O que mais me comovia era, de fato, o que me fazia "mover com" Novecento.

O narrador ${ }^{1}$, exímio trompetista que se torna companheiro e melhor amigo de Novecento, quando da sua inusitada decisão por permanecer no navio, mesmo com as infinitas chances que poderia vir a ter, descendo de lá, afinal, saindo para o mundo, sintetiza seu estarrecimento, fazendo a crucial pergunta:- "Perché non scendi, Novecento?" (BARICCO, 2004, p. 34) ${ }^{2}$

Esta espécie de desconforto ou desilusão, ante a escolha do protagonista por abdicar, conscientemente, da possibilidade de participar e intervir no mundo, para além do confinamento daquele navio, gera estranhamento e indignação no leitor (tal como ocorrera com o amigo-narrador, inconformado). Porém, foi exatamente este tipo de estremecimento que me arrebatou. Em meu íntimo, ainda que de modo intuitivo, eu parecia saber a resposta... Eu compreendia, sim, o porquê daquela, aparentemente desatinada, escolha.

Entre os tantos questionamentos suscitados por esta obra, o que me tomou, num primeiro momento, foi o da complexa discussão em torno do conceito de liberdade. Afinal, o que estaria escondido, por trás da decisão daquele homem? Estaria o narrador com a razão, ao supor que ele seria mais feliz, libertando-se daquele confinamento da "proa a popa", e assumindo, enfim, uma identidade, uma existência no mundo fora do navio? Seríamos nós, habitantes desta realidade sufocante e opressora, que nos violenta a cada dia, num maquiavélico aparelhamento ideológico que, tal como propõe Adorno,

\footnotetext{
${ }^{1}$ Permitimo-nos definir como "narrador", o personagem trompetista amigo de Novecento, pois, embora tenha sido, originalmente escrito para teatro (o que nos impediria, teoricamente, de pressupor a existência do narrador, como o que conta a história), o próprio Baricco, em preâmbulo ao livro, declara tratar-se de uma obra inclassificável, quanto ao gênero, podendo ser plenamente concebível como um conto para ser lido em voz alta. Ver referência a este preâmbulo, no $1^{\circ}$ capítulo desta pesquisa.

${ }^{2}$ - Por que não desce, Novecento?
} 
"reifica"(ADORNO, 2002, p.200) tudo e todos, essencialmente livres? A opção de Novecento não poderia ser lida como um grito de liberdade às avessas? Não estaria ele, ao rejeitar o mundo real, no fundo, pondo o dedo em nossa própria ferida, que de tão antiga já nem parece doer, a ferida anestesiada dos cárceres quotidianos a que somos submetidos?

Foi, portanto, por essa espécie de inquietação, que, primeiramente, me deixei conduzir e arrebatar pela obra de Baricco. Depois desta leitura inaugural, senti necessidade de ler seus outros romances, ensaios, textos jornalísticos e dramáticos.

Para minha feliz surpresa, fui descobrindo, para além das malhas encantadas de sua tessitura criativa, um intelectual, atilado com seu tempo, um filósofo, cujas idéias são comprometidas com a urgência de desautomatizar o homem, alienado e oprimido, nesta sociedade algemada por infindáveis e tirânicos condicionamentos.

Nesse sentido, entre os tantos motivos que me conduziram a optar por este autor, gostaria de reiterar o fato de que não é possível analisá-lo, sem perceber, em seu estar no mundo, um comportamento que indica sinais de coerência entre o ficcionista e o pensador atuante, que se insere e se posiciona, que toma partido e não fica à margem do processo. Talvez, de modo não muito distante daquele a que apontou o filosófo alemão Jürgen Habermas, em artigo publicado no "caderno Mais" da Folha de São Paulo, a propósito do papel do intelectual, na esfera pública, qual seja o de desenvolver um "faro vanguardista para a relevância" (HABERMAS, 2006, p.4-5). Diz ele que o intelectual deve intervir quando o cotidiano sai dos trilhos e irritar-se sobre desenvolvimentos críticos, num momento no qual os outros ainda se detêm na pasmaceira habitual. É o que, em boa medida, parece fazer o escritor Alessandro Baricco.

Gostaria, ainda de lembrar, que, naquela mesma época em que li Novecento, acabei lendo, também, o conto de Dino Buzzati: La libertà (BUZZATI, 1963) e foi inevitável não perceber alguns traços de evidente diálogo entre as duas obras. Tanto foi assim, que meu projeto inicial (com o qual participei do Congresso Italiano sem Fronteiras, XI congresso da ABPI, em Foz do Iguaçu, em abril de 2005) visava tratar dos dois textos, evidenciando, sobretudo, o modo pelo qual, cada autor, guardando suas peculiares características, transfigurava, em seu fazer literário, a seríssima discussão sobre o conceito de liberdade. Notando, porém, aos poucos, que o projeto tendia a se centralizar 
na obra de Baricco, optei por reorganizar o texto, citando, apenas como uma referência importante para a compreensão das questões conceituais do tópico "liberdade", o conto de Buzzati (conforme tentarei demonstrar no $2^{\circ}$ capítulo deste estudo). Conforme o que pretendo desenvolver, meu objetivo não será o de um debruçar-me sobre o conto de Buzzati, mas sim o de tomá-lo como apoio às minhas indagações.

Aos poucos, minha pesquisa foi se definindo e crescendo. Percebo muitos outros motivos, além dos previamente enunciados, para a escolha deste autor. Cito, apenas de passagem, os seguintes:

- a fundamental questão da liberdade;

- as dualidades recorrentes: finito/infinito; limite/ilimitado; contar/não

contar; ver/não ver; dentro/fora; fronteira/universo; micro/macrocosmo;

- a necessidade de despertar nossos olhares sonolentos, para reaprender a ver o mundo;

- o sentido que as histórias contadas têm e o poder que carregam de nos fazer conferir sentidos ao viver;

- a chance de resgatar o homem emudecido e, afinal, nossa humanidade perdida.

Por uma feliz coincidência, Alessandro Baricco, esteve no Brasil, entre 12 e 21 de maio de 2006 para participar do "Boca do Céu - II Encontro Internacional de Contadores de Histórias: Narrativas e Narradores", promovido pelo Sesc- Pinheiros, em São Paulo-SP. Nessa ocasião, pude me inscrever na oficina que ele ministrou, além de ter conseguido entrevistá-lo. As idéias que surgiram, a partir de tão importante encontro, geraram material autêntico e fidedigno, capaz de elucidar várias das reflexões que buscarei desenvolver, na presente pesquisa ${ }^{3}$.

Apenas para não me restringir ao que me inspirou Novecento (NV), mencionaria as múltiplas possibilidades de estudo que se abrem, em torno das várias, infinitas vozes que narram, que tocam de perto as velhas narrativas orais, em Castelli di rabbia (BARICCO, 1999), o primeiro romance do autor. Há, também, uma nítida correspondência entre essa diversidade de vozes, e os diferentes, sempre novos, pontos

\footnotetext{
${ }^{3}$ Transcreveremos a íntegra da entrevista em anexo (apêndice), material que rendeu a publicação: "Entrevista com Alessandro Baricco: à procura do velho narrador que habita em cada um de nós" na revista de Literatura e Arte ETCetera, Curitiba: Travessa dos editores, n. 9, setembro-2006, p.186-193.
} 
de vista, que surgem em Oceano mare (BARICCO, 1999), para aqueles que vão à estalagem Almayer, a fim de reaprender a ver o mar, tendo, como mestres, as crianças, seres não contaminados pela cegueira que assola, hoje, a humanidade. A intrigante história de Ultimo Parri, protagonista de Questa storia (BARICCO, 2005), romance recém-escrito, que, tendo participado da primeira guerra mundial, especificamente da Batalha de Caporetto, nos remeterá, junto aos demais companheiros, à terrível dificuldade de narrar o horror.

Em todos os livros e textos que me proponho a analisar (em especial, Novecento e Castelli di rabbia), guardando o que cada um pode oferecer de mais particular, noto, como espécie de fio a alinhavar o grande bordado, uma interessante e fortíssima recorrência, quase como uma espécie de bordão de sua profissão de fé: a urgência de fazer renascer o velho narrador, que habita em cada um de nós:

La verità è che si vedono e si sentono e si toccano così tante cose... è come se ci portassimo dentro un vecchio narratore che per tutto il tempo continua a raccontarci una storia mai finita e ricca di mille particolari. Lui racconta, non smette mai, e quella è la vita... Ci sono certi che lo chiamano angelo, il narratore che si portano dentro e che gli racconta la vita. ${ }^{4}$ (BARICCO, 1999, p.116)

Talvez, por ainda acreditar nos velhos narradores, que, segundo Baricco, são chamados de anjos, eu tenha escolhido, para este estudo, um título que me pareceu, a princípio, adequado.

No fundo, espero que, voltando a ter o prazer de fruir histórias, quase como que miticamente, retornando ao calor do fogo ancestral, possamos expurgar nossos demônios, dançando com os anjos, a música infinita, que só Novecento sabe fazer vir do mar...

Assim sendo, a presente pesquisa terá, como dois grandes eixos de orientação, os seguintes, que abordaremos, respectivamente, no $1^{\circ}$ capítulo :

\footnotetext{
4“A verdade é que se vêem, se sentem e se tocam assim tantas coisas... é como se trouxéssemos, dentro de nós, um velho narrador que o tempo todo continua a nos contar uma história rica em mil detalhes e que jamais termina. Ele conta, não desiste nunca e isso é a vida... Há alguns que o chamam de "anjo", o narrador que trazem dentro de si e que lhes conta a vida." - ( trad. nossa)
} 
A) a constatação de um problema: o crescente processo de desumanização da sociedade contemporânea.

B) a arte de narrar em Baricco: a narrativa como resistência; possíveis reflexões em torno do problema.

No segundo capítulo, buscaremos analisar "Novecento", com ênfase, sobretudo à problemática da relativização do conceito de liberdade.

No terceiro capítulo, pretenderemos compreender melhor como, em "Castelli di rabbia" parece haver a reinvenção do "velho narrador que habita em cada um de nós".

Importa lembrar que, a princípio, havíamos pensado em trabalhar, também com "Oceano mare", numa perspectiva de análise que complementaria as duas anteriores, pois focaríamos a problemática em torno da reeducação do olhar. Porém, devido às infinitas possibilidades de estudo que foram surgindo durante o transcorrer desta pesquisa, achamos por bem, analisar este terceiro romance em outro momento. 


\section{$1^{\circ}$ CAPÍtULLO: \\ A DESUMANIZAÇÃO DA SOCIEDADE CONTEMPORÂNEA}

\subsection{O Crescente processo de desumanização da sociedade contemporânea}

Se pensarmos no homem que volta do pós-guerra, em especial das duas grandes guerras que marcaram tragicamente o século XX, podemos afirmar, com Benjamin, que este homem, violentamente ferido, é o que foi obrigado a emudecer. $\mathrm{O}$ autor de "O Narrador" afirma: "Com a Guerra Mundial começou a manifestar-se um processo que, desde então, não se deteve. Não se notou, no fim da guerra, que as pessoas chegavam mudas do campo de batalha - não mais ricas, mas mais pobres em experiência comunicável?’(BENJAMIN, 1980, p.57)

De fato, este emudecimento atingiu radicalmente uma de nossas faculdades essenciais: a de trocar experiências. No limite, passamos a viver quase que uma tragédia da expressão, que se mantém e perdura, na falta de voz e no olhar embotado de seres, que já não conseguem ver, nem contar o mundo, porque perdidos no universo poluído e saturado de imagens e apelos de uma sociedade que reifica tudo.

Herdeiros de Hiroshima, holocaustos, final de utopias, a violência que nos assola, hoje, aponta para um novo trágico, que "reflui da exterioridade onde sempre parece ter sido o centro, para o seu núcleo primordial: a Linguagem”.(LOURENÇO, 1994, p.28)

Ivone Bordelois nos faz atentar para o tipo de violência dirigida contra a palavra, percebendo o quanto os chamados "meios de informação, comunicação ou entretenimento" acabam por confinar a expressão, distorcendo e deturpando mentalidades. Assim, diz ela:

Os romanos faziam do circo um espetáculo para obliterar a vida política; os meios atuais montam o circo da vida política e ao circo a reduzem. Mas a palavra entregue ao poder não é linguagem, mas pura consignação, mandato, exploração, alheia à preciosa liberdade, que é o destino profundo da verdadeira palavra humana. E nunca como agora cabe dizer que os fins não justificam os meios. (BORDELOIS, 2005, p.30) 
Além dessa questão do emudecimento, o que constatamos, hoje, é a existência de uma massa homogênea, amorfa de indivíduos, que vai perdendo suas singularidades, por meio de verdadeiras armadilhas de alienação e condicionamentos. Mesmo sem termos consciência disso, somos, como propõe Adorno, "prisioneiros a céu aberto".(ADORNO, 2002, p.200)

Imersos na amplidão do universo caleidoscópico da cibernética, nunca tivemos, como hoje, assim tão ao alcance das mãos, um mar de infinitas imagens, informações, trocas de experiências virtuais de todo gênero e espécie. O mundo todo conectado, plugado, informatizado, globalizado. E no entanto, nunca fomos tão escravos do Império da Inteligência Artificial, como alerta R. Kurz, ao definir a atual "sociedade da informação":

Ao que parece, a vida social e intelectual na sociedade do conhecimento - aliás da informação - deve ser levada a um caminho de comportamento que corresponda a um sistema de reflexos condicionados: estamos sendo reduzidos àquilo que temos em comum com cães, pois o esquema de estímulo-reação dos reflexos tem tudo a ver com o conceito de informação e "inteligência" da cibernética e da informática. (KURZ, 2002)

Subjacente às armas utilizadas pelo aparato do poder, na manutenção desse inferno dos condicionamentos, articula-se um tipo de discurso, que faz a apologia do imediato, de uma espécie de fast-food-delivery do pensamento, cuja indagação crucial é, sempre, "para que isso serve?", “a que fim se destina?” É o Discurso Utilitário, pragmático em detrimento do Discurso Estético ${ }^{5}$.

Em síntese, hoje, os mecanismos de repetição, produtividade, praticidade, acabam por gerar uma supervalorização do útil, do prático, do ágil, que podem conduzir a uma verdadeira atrofia dos sentidos. Poderemos pensar, apenas a título exemplificativo, no bombardeio de imagens a que nossos olhos são submetidos, dia a dia. De um lado, vende-se a idéia de que todo aquele universo está pronto para ser consumido, pela avidez de nossos

\footnotetext{
${ }^{5}$ Aqui, gostaríamos de entender o conceito de "Estético", fundamentalmente, a partir de como Friedrich Schiller o concebe, em sua obra: "Cartas sobre a educação estética da humanidade" e, também, de acordo com o que Adorno nos ensina, a esse respeito, em sua "Teoria Estética", conforme verificaremos no desenvolvimento desta pesquisa.
} 
olhares curiosos. Porém, a outra face da moeda é a do esgarçamento inevitável decorrente do apelo excessivo de informações visuais-verbais-auditivas. Se vivemos a ilusão de que o mundo inteiro pode ser conquistado por meio do www.com., o desgaste causado por uma overdose de ofertas e imagens de todo gênero conduz à pior de todas as cegueiras: a de imaginarmos que estamos vendo tudo, sem, em essência, "ver" de fato. E aqui não há como não lembrar o Ensaio sobre a Cegueira (SARAMAGO,1995), Palomar (CALVINO, 2006), o documentário Janela da Alma (CARVALHO \& JARDIM,2001), entre tantos outros.

Tudo que tentamos expor aqui, em resumo, nos faz atentar para as reais circunstâncias que colaboram, de modo definitivo, para a desumanização do homem, em nossos dias.

Uma vez constatado o problema, prosseguiremos, buscando compreender como Alessandro Baricco, autor italiano contemporâneo, lida com essas questões, atualizando, em termos ficcionais e ensaísticos, muito dessa angústia. Em suma, pretende-se verificar com que procedimentos, basicamente os voltados para a estrutura narrativa, e também pela recorrência a certos temas, o autor responde, como artesão da palavra, às tantas inquietações já anunciadas.

Antes de tudo, encanta-nos, com o policromatismo das infinitas nuances que suas histórias representam. Crê, efetivamente, na transfiguração literária, como encantamento. Mas, vai além. E isso não é só conjectura, visto que, na entrevista que nos concedeu recentemente, confirma sua crença numa "missão" transcendente e comprometida da arte (BARICCO, 2006, p.186-193).

Parece-nos que, diante da desumanização crescente que nos violenta, dia a dia, em última análise, ele busca propor, por meio de seu fazer artístico, uma espécie de "saída de emergência”. É claro que nada é assim tão simples, até porque seria extremamente redutor imaginar que a literatura, em especial no caso que nos cabe analisar, poderia assumir uma finalidade, uma função, um propósito, sendo mero instrumento, por meio do qual o autor, como uma espécie de paladino ou profeta, concentraria toda sua criação no engajamento panfletário dos manuais de instrução de como ajudar a salvar o mundo...

Ao trabalhar com dicotomias, tais como as que pretendemos apontar, no desenvolvimento deste trabalho, Baricco não nos dá "verdades" prontas, não se arroga 
como o detentor daquele que nos conduzirá a algum tipo de saída milagrosa. Não parece ser um autor de convicções, já que descende da linhagem de autores assistemáticos e muito mais experimentais, autores que rechaçam a idéia fossilizadora e estéril dos sistemas. ${ }^{6} \mathrm{O}$ que fica, a partir da leitura de sua ficção, é a dúvida, pois ele não deseja persuadir, mas inspirar.

Desta forma, ao lidar com elementos aparentemente antitéticos, tais como dentro $\mathrm{x}$ fora, prisão x liberdade, finitude x infinito, limitado x ilimitado, contar x não contar, olhar x não olhar, micro x macrocosmo, ele acabará tocando, de perto, os paradoxos da existência humana. $\mathrm{O}$ que suas obras produzem não é o mero reconhecimento, mas a reflexão. Nesse sentido, verificaremos que os universos que cria, se constroem e destroem facilmente. E teremos aí, conforme demonstraremos no desenvolvimento deste estudo, a beleza do impermanente e da queda. Nada pode ser estável, pois tudo muda o tempo todo, no mundo.

Assim, o navio, espaço móvel flutuante, em que vive Novecento (BARICCO, 2002), personagem, também instável, também flutuante, que não deixa de ser uma continuação anímica do espaço físico "navio", aparece e desaparece (Novecento morre quando o navio explode) vivendo apenas enquanto o narrador conta a história.

O belíssimo trem, construído pelo sr.Rail, em Castelli di rabbia (BARICCO, 1999) um trem de alma feminina, que passa a se chamar Elisabeth, concebido a partir da matéria prima do pó do sonho, construindo-se a partir de uma idéia, assumirá, por um tempo, a materialização física da realidade concreta, para acabar esfacelado em pedaços.

O mesmo se dará com o Crystal Palace, projeto de vida inteira, idealizado por Hector Horeau, monumento de vidro, que após brevíssima existência, se romperá em milhares de cacos.

Em Oceano mare (BARICCO, 1999), a estalagem Almayer, para a qual se dirigem todos os personagens, que têm alguma coisa a buscar no mar, ao final da história, se dilui, como castelo de areia, de duração efêmera, sucumbindo às primeiras ondas.

Ainda a lembrar, a famosa pista de corrida, projetada por Ultimo Parri, em Questa storia, que afinal se concretiza pelo capricho mirabolante de Elizaveta, a milionária que a

\footnotetext{
${ }^{6}$ Tomamos, nesse sentido, a definição de "experimental" em contraposição a de "homem de convicção" dada por Milan Kundera, ao aprofundar a questão do posicionamento radical de Nietzche, quanto à esclerose dos sistemas, tema ao qual retornaremos, oportunamente, no $2^{\circ}$ capítulo desta pesquisa. (KUNDERA, 1993, p.158-159)
} 
faz construir, para, logo após vivenciá-la numa única experiência excêntrica, destruíla.(BARICCO, 2005)

Em todos esses exemplos, chama a atenção essa impermanência, que, em nosso entendimento, é coerente com a grande trama ficcional de Baricco, qual seja a de se pautar pela relativização do contar, do ver, do apreender o mundo, a partir da dúvida, como única certeza.

Nossa pesquisa procurará, então, constatar as diversas estratégias usadas pelo autor, nesse magnífico jogo literário, a fim de propor uma série de questões sobre algumas verdades que nos são dadas como únicas, como indubitáveis.

Embora, cada uma das obras a serem analisadas assumam traços bastante peculiares, cremos que há um fio condutor a orientá-las. Neste estudo, percebemos que há uma correspondência dialética entre as formas de narrar e o que se narra. Assim, partindo do pressuposto de que forma e conteúdo são elementos indissociáveis que compõem toda obra de arte, notamos que a tessitura do narrar, em Baricco, se utilizará (conforme passaremos a verificar) de alguns pressupostos regidos basicamente pela necessidade de relativizar o ato de contar em si, intimamente associado à necessidade de relativizar o ato de ver. Para tanto, há uma escolha por explorar, ao máximo, as diversas vozes narrativas, o que enfraquece a voz onipotente de um único narrador, de uma única consciência narrativa.

Além disso, pretendemos demonstrar que, na temática recorrente em torno das infinitas possibilidades de ver, há também, como que uma equivalência entre o que estamos denominando "emudecimento" do homem contemporâneo e a "cegueira" generalizada que vivemos. Melhor dizendo, do mesmo modo que Baricco traz à luz a procura do velho narrador que habita em cada um de nós, também quer nos propiciar a oportunidade de alargar nossa visão, criando vários personagens instigantes, que vêem aquilo que os demais não conseguem. Poderíamos afirmar que à multiplicidade de vozes correspondem as infinitas possibilidades do olhar, pois, nesse universo ficcional, parece ser importantíssimo relativizar a ordem das coisas, fazer ouvir o que teve que calar, fazer ver o que acabou cegando. Concedendo a palavra a diferentes narradores, teremos diversos pontos de vista acerca do que nos é contado. E o que se conta parece ficar à mercê de quem e do modo como conta. 
Da mesma forma, quando, diversas vezes, nos depararmos com personagens que permanecem horas e dias "vendo" o mar, concluiremos quão limitado é o modo de perceber o mundo, quando se deixa de observar a realidade, sob diversos ângulos, já que nada permanece o mesmo, num universo mutante e instável, que exige olhares menos rígidos, menos formatados, menos acomodados.

Então, já que o homem que volta do pós-guerra volta empobrecido em experiências comunicáveis, não há mais o que narrar, não há mais o que trocar. A isso corresponde o estreitamento da visão. Segundo Saramago, nunca vivemos, como agora, o mito da caverna de Platão. Temos a impressão de que vemos muito, de que nossa visão se ampliou, já que a realidade oferece imagens de toda espécie, ao nosso alcance imediato. Mas esse bombardeio visual, ao qual corresponde o bombardeio das informações, nos deixou completamente perdidos, pois a realidade virtual é que passa a substituir a realidade, dandonos a mesma ilusão das sombras, vistas pelo homem da caverna platônica.(SARAMAGO, 2001)

\subsection{A Narrativa como resistência}

Alessandro Baricco, nascido em Torino, em 1958, graduou-se em Filosofia, estudou piano no conservatório de música, trabalhou como copista e dedicou-se à crítica musical. Seus primeiros trabalhos editoriais no campo da crítica musical foram Il genio in fuga (1988), sobre Rossini e L'anima di Hegel e le mucche del Wisconsin (1993), que trata da relação entre música e modernidade. Começou a escrever sobre música no La Repubblica (jornal em que continua colaborando com diversos ensaios relativos à arte, música, teatro, cinema e cultura em geral) e, em seguida, como colunista de cultura no La Stampa.

É um autor cuja força criativa se traduz nas mais diversas formas de expressão artística. Ao lado da vasta produção de romances: Castelli di rabbia ( 1991, romance de estréia, que ganhou o Prêmio Campiello e o Prix Médecis étranger em 1995 - já publicado na França, Alemanha, Holanda, Dinamarca, Noruega e Portugal), Oceano mare (1993), Seta (1996), City (1999), Senza sangue (2002), Questa storia (2005), publicou vários ensaios, entre os quais um dos mais intetressantes Next (2002) aborda a problemática da globalização. Também escreveu para teatro: Novecento (1994) e Omero, Iliade (2004), Partita spagnola (2003). Há, ainda, a lembrar, as antologias Barnum (1995) e Barnum 2 
(1998), e o livro escrito com Roberto Tarasco e Gabriele Vacis: Balene e sogni (2003), que busca resumir, um pouco, da interessante experiência do projeto Totem ${ }^{7}$. Em 1993, apresentava o programa de rádio L'amore è un dardo, dedicado à ópera, onde tentava estabelecer uma ponte entre esse mundo fascinante e ao mesmo tempo desconhecido pela maioria das pessoas.

Baricco, também, criou um programa para a televisão italiana, junto à jornalista Giovanna Zucconi, Pickwick, del leggere e dello scrivere (1994), voltado à literatura e a escola de narrativa Holden, em Torino, onde são ministrados cursos de técnicas narrativas para roteiros, jornalismo, videogames, novelas e contos. Esta escola foi fundada por ele e um grupo de amigos e o nome é uma homenagem ao personagem de J. D. Salinger, Holden Caulfield. Leciona até hoje na Holden, embora viva em Roma. Escreve, atualmente, episódios semanais, no jornal La Reppublica, com o título: Viaggio alla ricerca di nuovi barbari e acaba de publicar uma história em quadrinhos, em que reescreve Novecento: Topolino - La vera storia di Novecento (2008). Mickey faz o papel do narrador e conta à Minnie a história de seu amigo Novecento, no caso, Pateta. Além de tudo isso, está iniciando um trabalho como diretor cinematográfico. Do romance Seda, surgiu o filme Silk que deve estrear em breve.

O autor também deverá vir ao Brasil para participar da próxima Feira Literária de Parati -RJ (FLIP), em Julho deste ano (2008).

A opção por trabalhar com este autor deu-se, em boa medida, porque, como filósofo, ensaísta, ficcionista, intelectual ativo e participante de sua época, ele parece criar, por meio de seu fazer artístico, um modo de resistir à violência que vivemos, hoje, na sociedade aprisionante dos condicionamentos, tal como precisamos em capítulo anterior.

\footnotetext{
${ }^{7}$ Totem foi um projeto experimental que levou ao palco, teatro, "peças do mundo" de música, literatura, ópera: o espetáculo. Leituras, sons, aulas, com participação de Eugenio Allegri, Gabriele Vacis, Stefania Rocca e Lella Costa, contando, por exemplo, com a revelação do final de Guglielmo Tell, il Viaggio al termine della Notte di Céline, le Cattedrali di Carver, recitação de trechos de obras de Joseph Conrad, James Joyce e muito mais. O show, absolutamente inovador, permaneceu em cartaz numa bem sucedida turnê pela Itália até Agosto de 2001. O livro que conta, em detalhes, o que representou esse projeto se intitula: "Balene e sogni - Leggere e ascoltare. L'esperienza di Totem”, escrito por Alessandro Baricco, Roberto Tarasco e Gabriele Vacis, publicado pela Einaudi, Torino, em 2003 (será uma de nossas referências no presente estudo)
} 
Em outros termos, há uma profunda coerência, na obra de Baricco, se a tomarmos, em conjunto. O que ele pensa como filósofo, o que escreve como romancista, jornalista, dramaturgo, ensaísta, além de tentar atualizar muito de sua ideologia, na experiência de Totem, em última instância, acusam as questões cruciais de nossos tempos, trazendo como resposta, uma espécie de "reeducação dos sentidos", ou como quer Fernando Pessoa, a busca por uma verdadeira "erudição da sensibilidade". (PESSOA, 1999)

A fim de verificar como essa arte de narrar se configura, escolhemos analisar, Novecento (BARICCO, 2002), Castelli di rabbia (BARICCO, 1999), Oceano mare (BARICCO, 1999). Pontualmente, lançaremos mão do livro sobre o projeto Totem, De balene e sogni (BARICCO, TARASCO, VACIS, 2003), além de Barnum - Cronache dal Grande Show. (BARICCO, 2004, V.I e II)

Para cada uma das obras analisadas, nosso principal enfoque será o de verificar, como o autor faz uso de específicos procedimentos narrativos, a fim de recuperar o "velho narrador" que habita em cada um de nós, revigorando o simples ato de contar histórias, para, em boa medida, resgatar uma parte de nossa humanidade que acabou por se perder.

Baricco nos apresentará, com instigantes pontos de interrogação, alguns temas centrais da própria condição humana, tais como os da liberdade, dos limites espaciais e psíquicos, que podem ou não nos confinar; da urgência de nos fazer ampliar nosso olhar, a fim de que possamos exercitar a riqueza dos diferentes pontos de vista, reaprendendo a ver o essencial. E vai além! Por exemplo, em seu último romance Questa storia, há um projeto de relativização do que vem a ser a História Oficial, a que se institui e se confirma, graças ao aparato ideológico do poder. Percebe-se nítida a necessidade por parte do autor de desmistificar os tão estigmatizados fatos históricos, a ponto de revertê-los, de recontá-los sob uma outra ótica completamente diversa, qual seja a da História que não apareceu, que não foi revelada, a da que ficou nas entrelinhas ou foi propositalmente esquecida. É o que, em síntese, extraímos do que nos conta Elizaveta, uma das personagens do livro:

\footnotetext{
${ }^{8}$ A expressão "velho narrador", utilizada, explicitamente, por Baricco, em Castelli di rabbia, à p.116 é extraída do texto, mencionado logo, na introdução desta pesquisa: O narrador, de W. Benjamin.
} 
Io mi rifiuto di credere alla Storia. La Storia è un'illusione ottica. Sono solo faccende di pochi, vendute come se fossero la vita di tutti. Ma non è vero. È roba loro. (BARICCO, 2005, p.154, grifo nosso) ${ }^{9}$

Finalizando, importa notar a existência de um apelo a que não nos deixemos levar pela obviedade alienante do que é, digamos assim, "facilmente digerível" ou "palatável". De fato, a cada leitura, descobrimos a sensação aprazível da graciosidade lúdica (veja-se, a exemplo, a preferência pelo tom fabular, alegórico), que nos remete a histórias que se abrem em outras, num infinito mosaico de narrativas. Mas, nada disso é casual. Notamos, nesta aparente fragmentação, um todo, que evidencia uma instigante estratégia: a de saber jogar com a linguagem e com o leitor.

\subsection{Fundamentação Teórica}

Para cada capítulo deste trabalho, procurarei me apoiar em diversas fontes teóricas.

Obviamente e devido, inclusive, à profunda admiração de Baricco por este filósofo, me basearei, sobretudo, nas reflexões de Walter Benjamin acerca do Narrador (BENJAMIN, 1980, p.57-74), tendo em vista que, conforme já afirmamos anteriormente, uma das questões principais e recorrentes em todo projeto ficcional do autor aqui analisado prima por uma busca incessante daquela voz narrativa ancestral, tal como proposta no texto benjaminiano.

É pertinente observar que a oficina ministrada por Baricco, em São Paulo, no Encontro Internacional de Contadores de Histórias, teve, em seus três dias consecutivos, como fonte primeira, a leitura e análise do texto $O$ narrador: observações sobre a obra de Nikolai Leskow (BENJAMIN, 1962, p.247-274). A valorização deste filósofo e de sua obra, por Baricco, fez-se anunciar em diversas situações anteriores, por exemplo, quando em Janeiro de 2004, apresentou uma série de palestras, no Teatro Palladium de Roma, intituladas Leggendo Benjamin (BARICCO, 2004), em que trata (tal como na recente apresentação em São Paulo) da análise atenta e minuciosa do Angelus Novus (BENJAMIN, 1962, p.247-274), título da antologia de ensaios de Benjamin, do qual Baricco extraiu aquele específico sobre o Narrador.

\footnotetext{
${ }^{9}$ A propósito, lembramos do que comenta Dario Fo, citando uma frase muito interessante de Mao Tse Tung que diz o seguinte:"Il popolo da sempre fa la storia, ma poi sono i padroni che te la raccontano".
} 
As principais questões, levantadas por Benjamin e retomadas por Baricco, no texto mencionado (e que justificam sua escolha, como fundamentação teórica para este trabalho) podem ser assim resumidas:

- a arte de narrar está em vias de extinção e são, cada vez mais raras as pessoas que sabem narrar devidamente;

- estamos sendo privados de nossa faculdade de trocar experiências;

- o homem que volta da $1^{\mathrm{a}}$ Grande Guerra emudecido acaba sofrendo um tipo de trauma que pode ser traduzido, em termos contemporâneos, como o de uma ruptura irreversível, comparável à violência de Hiroshima, ao Holocausto e ao 11 de setembro;

- a experiência que passa de pessoa a pessoa é a fonte a que recorreram todos os narradores. As melhores narrativas escritas são as que menos se distinguem das histórias orais , contadas por inúmeros narradores anônimos;

- a arte de narrar está definhando, porque a sabedoria está em extinção (o narrador é o que sabe dar conselhos);

- a morte da narrativa está intimamente associada ao surgimento do romance e da informação, que se fortalece com o advento da imprensa (ligada à consolidação da classe burguesa);

- a narrativa é uma forma artesanal de comunicação: alma, olho e mão representam a tríade que faz pulsar o coração do artista.

Parece-nos que, a partir destas constatações, Alessandro Baricco busca uma revitalização da arte de narrar, porém não com uma visão nostálgica e passadista, mas com uma postura atualíssima, articulada com o complexo contexto artístico de nosso tempo. É ele mesmo quem nos alerta:

Nulla potrebbe essere più sciocco che vedere nel processo che ha espulso la narrazione solo un "fenomeno di decadenza", esso è un accompagnamento di forze produttive storiche, secolari, che ha espulso a poco a poco la narrazione dall'ambito del parere vivo e manifesta insieme, in ciò che svanisce, una nuova bellezza. Noi siamo la nuova bellezza.(BARICCO, TARASCO, VACIS, 2003, p.5) 
Se, conforme o que postula Benjamin, o narrador morreu, parece que o que Baricco propõe é uma reinvenção da narrativa, em moldes contemporâneos, o desenho de um novo rosto que a arte de narrar pode assumir, em tempos como os nossos.

Portanto, não se trata de uma reapropriação diletante e gratuita das idéias daquele filósofo, mas sim de uma tentativa de revitalizá-las, sob um novo prisma. Nesse sentido, Baricco se nutre das teorias de Benjamin, constata com o filósofo que, de fato, houve um esvaziamento do ato de narrar e propõe algo novo, novos procedimentos que levem em conta a geografia atual, sem se prender à visão melancólica, passadista e apocalíptica que lamenta o que ficou para trás e já não se pode mais recuperar.

A postura de Baricco, quanto às novas possibilidades do narrar, encontra-se muito bem explicada no livro que resume o significado do projeto Totem, escrito com Roberto Tarasco e Gabriele Vacis: Balene e sogni. Em capítulo específico, intitulado "Narrazioni e comunità", ele afirma que tem um modo particular de interpretar as coisas à sua volta, como se fossem "eventi di narrazioni" (eventos, fatos de narração - trad. nossa). Parte do pressuposto de que tudo possui uma dimensão narrativa muito forte. Desde a mais simples percepção de um objeto, no processo cognitivo humano, parece fazer parte de nossa natureza, essa necessidade de explicar as coisas ao nosso redor, de falar daquilo que percebemos e descobrimos, o que poderia ser traduzido, em boa parte, como essa "dimensão narrativa". E a narração acabará instaurando um certo tipo de relacionamento entre as pessoas, acabará conduzindo a uma "solidão partilhada" porque "dire narrazione implica una comunità di persone tenute insieme da quella narrazione" (falar "narração" implica na idéia de uma comunidade de pessoas ligadas, mantidas unidas por aquela narração - trad. nossa) (BARICCO, TARASCO, VACIS, 2003, p.18,19.)

Esse tipo de mentalidade não difere daquilo que aponta o interessante estudo de JOBIM e SOUZA (1996, p.189-206) a respeito das histórias orais. Segundo a autora:

Em uma sociedade oral, a maior parte de seu acervo cultural está fundada no círculo progressivo das lembranças das pessoas. Portanto, neste tipo de cultura, qualquer idéia que não seja periodicamente retomada e repetida em voz alta está condenada a desaparecer... Nas sociedades sem escrita, linguagem e memória são a base de todo o conhecimento possível. 
Ora, o que Baricco propõe, em Totem, por exemplo, é a lúdica experiência que advém do contato prazeroso com textos lidos em voz alta. Sua preocupação, mesmo que performática, centra-se nessa força da oralidade e na fruição do que se lê. Em grande parte, ao fragmentar as vozes narrativas em seus romances, conduzindo a certos "ruídos" procedimentos orais que interferem na escritura ${ }^{10}$ - é como se deixasse falar aquelas consciências narrativas, permitindo-lhes lembrar o ocorrido, cada qual com o seu modo peculiar de narrar, a partir de seu respectivo ponto de vista, a fim de que a força do narrador ancestral, de certa forma, não se perca e se reinvente.

Como afirma anteriormente, não é possível ver no fenômeno da chamada "morte da narrativa" apenas um sinal de decadência, porque seria totalmente ingênuo não perceber a situação no contexto histórico em que se apresenta.

Além de W.Benjamin, outro autor que será muito citado, como apoio para esta análise, será T. Adorno. Justificamos nossa escolha, tendo em vista alguns conceitos que explicam, exaustivamente, o percurso do processo de alienação a que vem sendo submetido o homem, numa sociedade que escraviza, condiciona e deforma, no sentido oposto ao que, de essencial, constitui o que pode se considerar "humano". Assim, para ele, a denominada "Indústria Cultural" visa a substituir a "Cultura de Massa", porque esta induz ao engodo que satisfaz os interesses dos detentores dos veículos de comunicação de massa. De fato:

Os defensores da expressão "cultura de massa" querem dar a entender que se trata de algo como uma cultura surgindo das próprias massas. Para Adorno, que diverge frontalmente dessa interpretação, a indústria cultural, ao aspirar à integração vertical de seus consumidores, não apenas adapta seus produtos ao consumo das massas, mas, em larga medida, determina o próprio consumo. Interessada nos homens apenas enquanto consumidores ou empregados, a indústria cultural reduz a humanidade, em seu conjunto, assim como cada um de seus elementos, às condições que representam seus interesses. A indústria cultural traz em seu bojo todos os elementos característicos do mundo industrial moderno e nele exerce um papel específico, qual seja, o de portadora da ideologia dominante, a qual outorga sentido a todo o sistema. Aliada à ideologia capitalista, e sua cúmplice, a indústria cultural contribui eficazmente para falsificar as relações entre os homens, bem como dos homens com a natureza, de tal forma que o resultado final constitui uma espécie de antiiluminismo... O homem tornou-se vítima

\footnotetext{
${ }^{10}$ Essa questão será bem desenvolvida no capítulo 3 deste estudo.
} 
de um novo engodo: o progresso da dominação técnica. Esse progresso transformou-se em poderoso instrumento utilizado pela indústria cultural para conter o desenvolvimento da consciência das massas. A indústria cultural - nas palavras do próprio Adorno - "impede a formação de indivíduos autônomos, independentes, capazes de julgar e de decidir conscientemente." (ADORNO, 1980, p. XVI-XVII, grifo nosso)

A partir daí, temos uma série de expressões como: "reificação", "prisão a céu aberto" (ADORNO, 2002, p.200), que nos servirão para explicar, em boa medida, o que estamos situando, nesta pesquisa, como a desumanização da sociedade contemporânea.

Mais especificamente, para Adorno, assim como para Platão, o mundo das aparências é um mundo de imagens e meras ilusões, um mundo de relativismo e de "reificação". Nessa mesma linha de pensamento, então, no mundo capitalista, as mercadorias assumem vida própria e acabam sendo instrumentos de alienação, na medida em que geram "consciências reificadas", que representam um momento do "mundo reificado". Como conseqüência, afirma ele que, contrariamente ao que possam pensar, os seres humanos não são livres:

eles têm formas restritivas de pensamento e ação impostas a eles pelas condições sociais existentes da produção capitalista; eles vivem na "prisão a céu aberto em que o mundo está se tornando". As pessoas se adaptam a essas condições, em vez de se opor a elas. Como conseqüência: "em um estado de não-liberdade, ninguém, obviamente, tem uma consciência liberada".(ADORNO, 2002, p.200)

Estes conceitos, definidos em diversas obras do filósofo, nos serão fundamentais, pois elucidarão boa parte das questões centrais propostas no decorrer deste trabalho, quais sejam as que tocam, mais de perto, o tema da liberdade e também, sem dúvida, o da valorização de um Discurso Estético, em oposição ao que entendemos como Discurso Utilitário.

Ao elaborar sua Teoria Estética, Adorno busca, principalmente, fazer com que a arte não fique reduzida à violência ideológica da indústria cultural. Na verdade, há como que 
"um desejo de preservar a santidade da subjetividade incorporada no objeto de arte contra o massacre do mercado, onde valor é equiparado a preço".(ADORNO, 2002, p.202)

Tendo em vista que, muito do que pretendemos, valorizará o repertório de procedimentos narrativos escolhidos pelo autor, trabalharemos, primordialmente, com o conceito de Literatura proposto por Roland Barthes em sua Análise estrutural da narrativa (BARTHES, 1972). Para ele, “a literatura é uma trapaça salutar, uma esquiva, um logro magnífico que permite ouvir a língua fora do poder, no esplendor de uma revolução permanente". Partindo de tal premissa, tocaremos na idéia do lúdico, buscando fundamentar nossas indagações, a partir de F. Schiller, na obra Sobre a educação estética (SCHILLER, 1963) e, como não poderia deixar de ser, com J. Huizinga: Homo ludens (HUIZINGA, 2004). Nosso intuito será o de demonstrar como a arte de narrar em Baricco, eminentemente lúdica, traduzida, por exemplo, em um tipo de estrutura que se compõe de histórias que se abrem em outras e assim sucessivamente, busca "distrair" o leitor de modo proposital, sem que isso comprometa a profundidade dos temas que aborda. Em síntese, no que é aparentemente gratuito, nessa permanência na viagem do texto sem rumo certo, sem ponto de chegada, há um requinte na criação de um universo lúdico, cuja leveza e prazer dialogam, de maneira íntima, com o que de mais fundo conduz a um pensar, a um refletir comprometido com a realidade, no que ela possa apresentar de mais cru e inusitado.

Além disso, ao tratar especificamente de cada uma das obras que aqui analisaremos, procuraremos voltar o foco da atenção ao fazer literário de Baricco, pois queremos perceber, na tensão que ele cria, por meio de tantos, vários procedimentos, um modo consciente de gerar o estranhamento, tão necessário, nestes tempos, assim chamados “hiper-modernos". (LIPOVETSKY \& CHARLES, 2004) Tempos em que se faz, cada vez mais necessário, um alerta, a fim de retirar a venda de nossos olhares poluídos, de nossas almas saturadas de imagens, ruídos, apelos, palavras que tudo dizem, sem, essencialmente, terem quase nada a dizer.

Como proposta desta pesquisa, verificaremos a recorrência, nos livros a serem estudados, dos elementos trazidos pelo autor, para, em última instância, propor uma reeducação dos sentidos, a fim de fazer surgir o que ainda nos resta de humano. Então, pareceu-nos muito pertinente trabalhar com alguns conceitos, tais como os que Bernardo Soares, o semi-heterônimo de Fernando Pessoa ensina, no Livro do desassossego. 
(PESSOA, 1999) Ele traz à luz o termo: "erudição da sensibilidade", traduzida como verdadeira experiência, pois é aquela que "consiste em restringir o contato com a realidade e aumentar a análise desse contato. Assim, a sensibilidade se alarga e aprofunda, porque em nós está tudo; basta que procuremos e saibamos procurar".(PESSOA, 1999)

Vários dos protagonistas das histórias de Baricco trazem o infinito em si mesmos, servindo como exemplos de personas que intensificam o contato com o real, já que capazes de uma vivência inteira, motivada, para além das aparências. Contrariamente ao que acontece com os mecanismos automáticos de homens robotizados, estes personagens e suas histórias recuperam o que de essencial pode vir a configurar sentidos à existência.

Novecento propõe que, não obstante os limites, você é infinito. Essa capacidade de transcendência do humano se revela, de modo muito evidente em, por exemplo, Bartleboom (de Oceano mare), em Mormy (de Castelli di rabbia), em Ultimo Parri (de Questa storia). Então, mesmo que haja confinamentos de toda a ordem, físicos, psíquicos, morais, alguns dos personagens de Baricco traduzem, em vez de medo, a esperança nas potencialidades que estão no homem, dentro e não fora dele. Daí o porquê da crença, não no saber que se nutre apenas da erudição ensimesmada, ou da aquisição acadêmica engessada, sistematizada e fria do conhecimento. Trata-se, como propõe o semi-heterônimo de Pessoa, de ressuscitar a sensibilidade, pois só ela pode fazer o humano entrar em contato com o humano.

Buscando ainda trabalhar mais acuradamente o conceito de reeducação dos sentidos, chama-nos a atenção o quanto Baricco investe na necessidade de descortinar nosso olhar. Assim, apenas a título ilustrativo, vale lembrar que em Novecento, a uma certa altura, o narrador trompetista, sem entender por que seu amigo permanece horas e horas contemplando o mar, lhe pergunta o que estaria fazendo. Este responde que estava vendo o mar. Ao que o outro replica, indignado, que fazia já trinta anos que ele estava vendo o mesmo mar! (já que ele só conhecia o "mundo" do navio, cercado pelo oceano, sem nunca ter saído...) Novecento, então, muito sereno, responde que nunca o vira a partir desse novo ângulo, desse novo ponto de vista e que o mar, jamais era o mesmo.

Portanto, haverá sempre um novo modo de ver, por mais que tenhamos visto algo, por mais que pensemos ter apreendido a realidade à nossa volta, é necessário alargar nossa visão. Não é outro o significado de inúmeras passagens, com a mesma temática, em 
Oceano mare, que apresenta como uma de suas principais reflexões (nos mais diferentes níveis), a das múltiplas perspectivas do olhar. Neste romance, todos os personagens que vão para a Estalagem Almayer se surpreendem com a inusitada (e, ao início, muito misteriosa) aparição de crianças, que surgem do nada e, aos poucos, vão se revelando como duplos daqueles adultos, como se fossem as crianças que, respectivamente, cada um deles, pudesse ter sido. Queremos crer que a intenção do aparecimento dessas criaturas, que sempre têm algo a ensinar, está relacionada ao fato de que, enquanto crianças, ainda não fomos totalmente alienados ou tragados pelo excesso dos condicionamentos, que passam a nos marcar quando nos tornamos adultos. Talvez, as crianças, em Oceano mare, possam ser vistas como tutores daqueles adultos embrutecidos, quase como miniaturas de esperança, capazes de desautomatizar o que está deformado, de sensibilizar o que já não consegue ver, nem sentir. Apenas para ilustrar o que estamos afirmando, transcreveremos um diálogo entre Bartleboom e o menino que lhe aparece, sem se identificar, menino que, ironicamente, trará, à tona, o que o adulto já não vê ou não está em condições de perceber:

O menino foi um pouco para lá no parapeito. Ar frio e vento do norte. À frente, até o infinito, o mar.

- O que você faz sentado aqui em cima o tempo todo?

- Olho.

- Não há muito o que olhar...

- O senhor está brincando?

- Bem, há o mar, certo, mas o mar afinal é sempre o mesmo, sempre igual, mar até o horizonte, com sorte passa um navio, afinal não é assim o fim do mundo.

$\mathrm{O}$ menino virou-se para o mar, virou-se novamente para Bartleboom, virou-se ainda para o mar, virou-se ainda para Bartleboom.

- Quanto tempo o senhor vai ficar?- perguntou-lhe.

- Não sei. Uns dias.

O menino desceu do parapeito, foi para a porta, parou na soleira, ficou uns instantes estudando Bartleboom.

- O senhor é simpático. Quem sabe quando for embora será um pouco menos imbecil.

Crescia, em Bartleboom, a curiosidade de saber quem as tinha educado, aquelas crianças. Um portento, evidentemente. (BARICCO, 1997, p.22, trad. Roberta Barni)

Já que estamos tratando da reumanização, da reeducação dos sentidos, de todas as mensagens que aparecem aqui e acolá, na obra de Baricco, insistindo nessa necessidade de 
redimensionar o olhar, achamos por bem buscar apoio teórico na fecunda antologia de textos reunidos, escritos por diversos professores, filósofos, intelectuais: $O$ olhar.

Entre eles, especialmente $O$ olhar iluminista de Sergio Paulo Rouanet (ROUANET In NOVAES, 2003, p.125-148). Nesse interessante estudo, o autor nos ensina o quanto a temática da chamada "pedagogia do olhar" foi presente na época da Ilustração. De fato, para vários filósofos daquele período, todo conhecimento dependeria dos sentidos, sendo necessário criar o que denominaram "educabilidade do olhar". Vejamos o que nos esclarece o seguinte trecho:

Mas se até a deformação visual produzida pelas leis do mundo físico pode ser vencida, com mais forte razão podemos vencer a que não é imposta pela natureza, mas pela sociedade. Aqui podemos falar, verdadeiramente numa pedagogia do olhar. Não se trata mais de compensar, pela ciência, um erro inevitável, mas de corrigir, pela educação, um erro contingente. É preciso combater pela educação a cegueira produzida pela educação. A educação repressiva cria os preconceitos, que funcionam como anteparos, bloqueando a visão, e como refratores, que dão do mundo social uma visão tão distorcida como a produzida, no mundo físico, pela ilusão de ótica. Ela ensina a não ver, e graças a essa não visão, o poder se torna intangível, pois seus verdadeiros mecanismos não podem ser desvendados. E ensina a ver o que não existe, gerando os "espectros e quimeras" de que fala a retórica da época, e cuja principal função é manter o homem no medo e na ignorância, perpetuando com isso, a hegemonia dos poderosos. (ROUANET In NOVAES, 2003, p.133, grifo nosso)

Aquilo que fascinou os filósofos da Ilustração, de algum modo, transposto para a modernidade, em termos de uma fenomenologia do olhar, serve como apoio para as nossas investigações. Sabemos que a questão do olhar é muito central no debate da cultura e das sociedades contemporâneas:

Um mundo onde tudo é produzido para ser visto, onde tudo se mostra ao olhar, coloca necessariamente o ver como um problema. Aqui não existem mais véus nem mistérios. Vivemos no universo da sobreexposição e da obscenidade, saturado de clichês, onde a banalização e a descartabilidade das coisas e imagens foi levada ao extremo. Como olhar quando tudo ficou indistinguível, quando tudo parece a mesma coisa? (PEIXOTO In NOVAES, 2003, p.361) 
Como não poderia deixar de ser, percebemos que Baricco ao perscrutar, indagar, aguçar, exacerbando, ao máximo, essa reeducação do olhar, conduz à ruptura dos limites entre sujeito-objeto. Nesse sentido, o que olhamos, também nos olha e o sensível transborda da essência à experiência, numa relação de intercomunicabilidade, de diálogo incessante e fecundo. Inevitável tomar, neste momento, como referência primeira, algumas das idéias centrais da fenomenologia de Merleau-Ponty. O que nos chama a atenção, em particular, é o modo pelo qual este filósofo investiu contra a concepção dual e dicotômica entre sujeito-objeto, fazendo sobressair a temática da reeducação dos sentidos, em especial da visão:

Já não se quer, portanto, privilegiar o pensamento cartesiano em prejuízo da visão encarnada. Assim, estamos longe também da base última do cartesianismo, a violência platônica do "olhar para o alto", fundamento de todo o Humanismo tradicional. A visão começa, enfim, como que a encontrar o seu endereço natural: a situação do homem enquanto debrucado sobre o mundo e a história. E o ser se faz olhar, visão. (MERLEAU-PONTY apud BORNHEIM In NOVAES, 2003, p.92, grifo nosso)

Ao nos referirmos, anteriormente, às crianças que aparecem, por exemplo, em Oceano Mare, percebemos um discurso que privilegia uma primeira apreensão do universo, quase a descoberta virginal do primeiro olhar, que, simbolicamente, associado à infância, remete ao que permanece em estado puro, não contaminado pelo saber oficial. Há diversas passagens no livro, que, reiterando essa necessidade de alargar os modos da percepção, suscitam diversas atitudes do ser em busca do essencial. Mas, a busca não reside apenas no instante contemplativo. Está, sobretudo, em sua vivência. Daí porque, todos os personagens de Oceano Mare remetam ao forte apelo dos sentidos, todos eles, de certa forma, buscando na Estalagem Almayer uma forma de salvação, querendo resgatar o que lhes fora negado, a partir do contato com o mar. O oceano mar, vivenciado por cada um deles a seu modo, terá a força de lhes conceder o contato íntimo consigo mesmos, a fim de que se curem de suas feridas existenciais. Então, se num primeiro momento, a narrativa se concentra em dar sinais de alerta para que todos reaprendam a olhar o mar, este, por sua vez, passa a exigir 
atitudes de mudança, diante da realidade plana, uniforme e sem questionamentos que eles, personas-humanas-aprisionadas na realidade dos condicionamentos, deixaram lá, nos lugares de onde partiram. Chegar à Estalagem Almayer e afrontar o oceano mar é já uma atitude de ruptura com o que está posto, com o que vinha sendo, até aquele momento, a verdade pré-estabelecida. O oceano mar é o mote que propicia a reflexão, a dúvida, freqüentemente inquietante e dolorosa, dos que se arriscam nessa viagem, que, em última instância, é a viagem mais desafiadora, pois a que se dá em direção aos labirintos mais inextricáveis do ser. E, simplesmente, parar, a fim de olhar o mar significa reverter o imediatismo de nossos olhares tão velozes, ágeis, superestimulados pela parafernália dos apelos imagéticos e das luzes neon, a que estamos nos habituando a cada dia. Olhar o mar significa, também ser visto por ele e se deixar tocar/ tragar/curar por ele. É por isso que, em grande parte, a temática do olhar em Baricco remete ao que propõe Merleau-Ponty. Somos sujeitos, enquanto olhamos, mas o que olhamos transcende a situação estática de meros objetos, na medida em que também somos modificados por aquilo que nos olha. De fato:

Desde o prólogo à Fenomenologia da percepção (1945), MerleauPonty postulava a necessidade de o filósofo acolher generosamente em si o mundo já dado, o mundo que Husserl intuíra como "précategorial", o mundo que "já está aî". Essa misteriosa realidade (no entanto, familiar e cotidiana) é a nossa escola do olhar, e o seu método encontra na descrição do fenômeno pictórico um terreno fértil de exercício.

Diversamente da posição agônica do Sartre de O ser e o nada, Merleau-Ponty começa por abrir-se ao olhar do outro, que, como o meu olhar, vive mergulhado no espaço fluido e aberto da visibilidade. Assim, o primeiro passo é estético (esfera onde o sensível já tem um sentido imanente), não "abstrativo", na acepção de "objetualista". O olhar fenomenológico vai descobrindo, perfil a perfil, os aspectos coextensivos ao olho e ao corpo, ao corpo e ao mundo vivido.

A descrição mais rica (embora nunca totalizada) desse olhar seria a que conjugasse o tempo todo, sinóptica e sinfonicamente, a visão e o corpo visto. $\mathrm{O}$ pintor realiza, no traçado de uma linha ou no matiz de uma cor, um enlace de olhar e mundo olhado, amar e mundo amado. Daí o seu papel exemplar no interior do discurso fenomenológico. MerleauPonty lembra o desabafo de Cézanne: "Que vão para o diabo aqueles que duvidam de que, unindo um verde matizado com um vermelho, se entristece uma boca e se faz sorrir a maçã de um rosto".(BOSI In NOVAES, 2003, p.81) 
Assim, o pintor Plasson de Oceano mare (por exemplo), cansado das fisionomias artificiais e presunçosas dos nobres que lhe pagavam muito bem para retratá-los, vai ao oceano mar, para pintá-lo e a tinta que ele usa, em seu quadros, é a própria matéria-prima, de que se encharca, quotidianamente, até os joelhos: a água salgada do mar. Ele precisa sentir o mar, além de olhá-lo muito, com paciência, humildade e devoção ritualística, precisa se sujar daquela tinta, misturar-se a ela, vivenciar aquela essência, experimentá-la, numa degustação mansa, a fim de extrair-lhe o sumo que usará em suas tentativas para representá-lo: o grande, infinito, irretratável mar.

Em Castelli di rabbia, essa mesma necessidade de conduzir à relativização do que se pressupõe como única verdade, único ponto de vista, concentra-se no artifício, muito bem realizado por Baricco, de conceder a palavra a diversas vozes. Conforme analisaremos em capítulo específico, particularmente neste romance, temos um leque de vozes narrativas que se abrem, de modo a fazer-nos perceber o quanto a realidade depende de como a apreendemos e do quão subjetiva e mutante é esta apreensão. Melhor dizendo, muito do que passamos a conhecer fica na dependência de quem narra a história e como não há uma, mas múltiplas e variadas consciências narrativas, estaremos diante de infinitos pontos de vista, tal qual Novecento e os personagens de Oceano mare, que percebiam múltiplas e sempre renovadas maneiras de ver aquele que jamais se reduziria a ser o mesmo mar.

Em Questa storia parece ocorrer uma urgência em reverter, ao máximo, aquilo que é dado como certo e verdadeiro. Assim, só a título de exemplo, a terceira parte, intitulada Memoriale di Caporetto, apresentará como que diversos "depoimentos" sobre o episódio daquela batalha, na Primeira Guerra Mundial. E a voz mais comovida e convincente passa a ser a do pai de um capitão italiano, morto como desertor, que, não se conformava com a "verdade" da história oficial, tida como indubitável. Procura, então, recompor o que o filho teria passado e vivido, entrevistando outros que pudessem tê-lo conhecido, que tivessem vivenciado o mesmo episódio, sobreviventes que tivessem algo a mais a contar, experiências a narrar, a fim de recuperar uma outra memória, um outro lembrar que conduzisse a uma nova perspectiva, aquela da história que não se contou e que ficou, subliminar e propositalmente, esquecida e negligenciada.(BARICCO, 2005, p.73-135)

Em todas essas obras, portanto, temos como forte recorrência, esse apelo, a fim de que não nos acomodemos a uma única verdade, a fim de que busquemos, incessantemente 
alargar nossa visão, para que não continuemos a ser vítimas do sistema da hiper-saturação de imagens, cujo excesso de luzes e informações estão, ao contrário do que possa parecer, nos cegando, já que estamos desaprendendo a ver, a buscar o essencial.

Também como base para nossa teorização acerca do literário, usaremos diversos textos críticos de Italo Calvino. Entre eles, o já citado na Introdução, I livelli della realtà in letteratura (CALVINO, 2002, p.374), Lezioni Americane (CALVINO, 1990), I nostri antenati- nota 1960 (CALVINO, 2005, p.413-422), Mondo scritto e mondo non scritto (CALVINO, 2002), Sulla fiaba (CALVINO, 1988), e algumas referências pontuais às obras: Le città invisibili (CALVINO, 1999) e Palomar (CALVINO, 2006).

Além de tratar das questões do texto literário tais como pretendemos analisá-lo, Calvino é fundamental para este estudo, já que representa para Baricco, quase que um guia, um importantíssimo pensador, do qual seria impossível não receber influências. Assim, ao tratar do projeto Totem, no livro Balene e sogni (BARICCO, TARASCO, VACIS, 2003, p.5) , o primeiro capítulo é inteiramente dedicado a Italo Calvino, com quem Baricco dialoga. O título é: "Una frase di Italo Calvino" e retoma o último diálogo entre o Gran Kan Kublai e Marco Polo, de Le Città invisibili. Trata-se do episódio em que os dois personagens tentam conceituar o inferno e Baricco o retoma ipsis literis, a fim de extrair dele, o que chamará de ponto de partida para contar a experiência do projeto Totem. Assim, ele busca enfatizar a fala de Marco Polo, que afirma que o inferno não é algo que virá, mas é aquele que já existe aqui, o inferno em que vivemos todos os dias, estando juntos. E continua:

Due modi ci sono per non soffrirne. Il primo riesce facile a molti: accettare l'inferno e diventarne parte fino al punto di non vederlo più. Il secondo è rischioso ed esige attenzione e apprendimento continui: cercare e saper riconoscere chi e che cosa, in mezzo all'inferno, non è inferno, e farlo durare, e dargli spazio. (BARICCO, TARASCO, VACIS, 2003, p.7, grifo nosso)

Baricco parte daí para resumir o que significou, em essência, Totem e vale a pena transcrever o que ele revela a respeito: 
Ciò che ci piace molto in questo brano non è tanto la sottolineatura sull'inferno - è molto pessimistica e non credo che né io né gli altri due, Roberto e Gabriele, abbiamo una idea così apocallitica di ciò che ci sta intorno,-, però non ci sfugge che il mondo è un mondo che non ci piace, ci sembra butti via dei valori importanti e riduca l'esperienza a uno scherzo dell'esperienza, mentre dovrebbe essere qualcosa di molto più intenso e dotato di senso: che sia insomma un mondo che svende se stesso, questo lo pensiamo. Questo senso di dover resistere a un processo colletivo apparentemente irrefrenabile di svalutazione dell'esperienza dell'umano, questo lo pensiamo e lo possiamo condividere con Calvino.

Di sicuro ci veniva di condividere con grande "esattezza", per usare il termine di Calvino, questa idea della "cura". Non tanto cioè scatenare rivoluzioni e fare gesti eclatanti, quanto il paziente, minuscolo lavoro di cura di ognuno di noi, che si china su qualcosa di apparentemente non così significativo, non così importante - e come dice Calvino lo fa "durare" (BARICCO, TARASCO, VACIS, 2003, p.5, grifo nosso)

Totem, para ele, nesse sentido, representou uma espécie de resistência pequena e comum, ordinária. A idéia era a de reverenciar algo aparentemente minúsculo, mas para ele e seus companheiros de viagem, importante, ritualístico, fazendo-o durar, perdurar.

Não nos parece simples acaso que, tanto Baricco como Calvino, tivessem profunda admiração pelo escritor Joseph Conrad. Até porque o que escreveram a respeito dele, foi bem além da admiração. De fato, o nome Locanda Almayer, escolhido por Baricco para a estalagem em que aportam todos os personagens de Oceano mare remete, sem sombra de dúvida, ao livro A locura do Almayer (CONRAD, 1999) de Conrad, escritor ao qual, ele quis homenagear, conforme o que nos contou na entrevista. (BARICCO, 2006, p.186-193)

Há, também, um interessante posfácio, escrito por Baricco, na edição italiana da Feltrinelli da obra Coração das trevas - Cuore di tenebra de autoria de Conrad, que teria inspirado o filme "Apocalipse Now" de Coppola. Nesse posfácio, intitulado: Andata e ritorno, destinazione l'orrore (BARICCO In CONRAD, 2003, p.113-121), há uma reflexão sobre o que Baricco denomina o modo "imperfeito" de narrar de Conrad, que, conforme verificaremos em capítulo específico (o segundo), nos servirá como apoio teórico, elucidativo sobre alguns aspectos dos modos de narrar, adotados pelo próprio Baricco.

Italo Calvino, pelo que consta, também dedicou uma tese ao mesmo escritor, tão admirado por Baricco: Joseph Conrad. 
Como já anunciamos anteriormente, nossa pesquisa tentará desvendar alguns dos procedimentos usados por Alessandro Baricco, que evidenciem:

- a multiplicidade de vozes narrativas, enfraquecendo, assim, a onipotência de um único narrador;

- a não linearidade proposital do enredo, que estruturalmente, vai se compondo de histórias que se abrem em outras e assim sucessivamente, sem aparente nexo lógico causal, suscitando no leitor, a sensação de que o início-meio-fim se perderam (a essa estratégia corresponde um certo "perder o fio da meada", também por parte do leitor, que, em decorrência dessa imprevisibilidade, acaba se "distraindo" com cada um dos episódios narrados, pelo simples prazer de fruir o texto, de permanecer na história, na viagem, sem se preocupar com o destino a que aquilo tudo possa levar);

- os fortíssimos traços de oralidade, que, em diversas situações (conforme verificaremos) anunciam uma arte de narrar que se volta, explicitamente, às enunciações espontâneas, muito próximas a um contar histórias descompromissado, que faz questão de esbarrar nas imperfeições, nos ruídos, no inacabado das genuínas narrativas orais;

- a intromissão irônica, incisiva, por parte do narrador (quando a consciência narrativa se concentra em uma só voz), visando, também, aproximar o leitor do universo ficcional narrado. Parece que, minimizando, ao máximo, o distanciamento que, em alguns romances tradicionais, poderia conferir um certo poder ao ato de contar, o autor consegue criar um efeito que toca, de perto, o discurso informal, ainda "não contaminado" pela organização das idéias muito bem escritas, calcadas na retórica do beletrismo;

- o requinte com que se utiliza da ironia, como procedimento implícito ao questionamento da realidade

- a correspondência entre a multiplicidade de vozes narrativas e os diferentes pontos de vista de alguns personagens que conseguem ver o que os demais não conseguem, o que poderia ser traduzido como a verdadeira liberdade que é a busca do essencial, a partir da reeducação dos sentidos

- o processo subjacente às tramas que desenvolve, muito orientado na busca da relativização das verdades postas sem questionamento, da visão estreita e formatada da nossa realidade, da revisão necessária de conceitos e crenças, sobretudo àquelas impostas pelo saber e pela História oficial; muitos dos recursos usados por Baricco, nesse sentido, 
traduzem-se na perspectiva de construir a narrativa da impermanência, do instável, do que não pode durar. Daí, sua escolha por trabalhar paradoxos, dicotomias, capazes de conduzir à reflexão e à dúvida, de inspirar mais do que persuadir.

Em todos os casos acima mencionados, nos utilizaremos dos textos das obras com as quais pretendemos trabalhar: Novecento, Castelli di rabbia, além da entrevista que pudemos realizar com o autor (conforme já nos referimos antes). 


\section{$2^{\circ}$ Capítulo}

\subsection{Novecento: A música infinita que vem do mar}

O monólogo Novecento, escrito para teatro, originou um espetáculo e o filme de Giuseppe Tornatore: La leggenda del pianista sull'oceano (1998).

$\mathrm{O}$ autor, de fato, nos revela que sua intenção, ao escrever este monólogo, era a de criar um texto para teatro ${ }^{11}$. Depois, acabou concluindo que se tratava de uma obra que poderia se prestar ao cinema ou simplesmente a uma leitura dramática. É o próprio Baricco, logo no preâmbulo do livro, quem nos avisa:

Ho scritto questo testo per un attore, Eugenio Allegri, e un regista, Gabriele Vacis. Loro ne hanno fatto uno spettacolo che ha debuttato al festival di Asti nel luglio di quest'anno (1994). Non so se questo sia sufficiente per dire che ho scritto un testo teatrale: ma ne dubito. Adesso che lo vedo in forma di libro, mi sembra piuttosto un testo che sta in bilico tra una vera messa in scena e un racconto da leggere ad alta voce. Non credo che ci sia un nome, per testi del genere. Comunque, poco importa. A me sembra una bella storia, che valeva la pena di raccontare. E mi piace pensare che qualcuno la leggerà. (BARICCO, 2002, p.7)

Trata-se da história de um menino, batizado pelo pai adotivo, Danny Boodmann T. D. Lemon Novecento, que nasce dentro de um navio, ali se torna um grande pianista e passa toda sua vida da proa a popa, sem nunca, jamais sair. A pergunta que o narrador (músico, exímio trompetista, que acabará sendo o melhor amigo de Novecento) coloca é a mesma que, de certa maneira, nós leitores, também faremos. Já que se tornara grande, podendo usufruir as maravilhas que o mundo lhe proporcionaria, como brilhante pianista que era, por que aquele homem opta por permanecer no navio, naquele aparente confinamento, inclusive, ao final, vindo a morrer, consciente de que sucumbiria lá dentro, explodindo, com o transatlântico? Parece que o que nos causa um certo "estranhamento" é o fato dele escolher a aparente prisão, em vez de sair para o mundo. Por que, enfim, tendo a

\footnotetext{
${ }^{11}$ Realmente, a peça teatral Novecento apresentou como protagonista o ator Eugenio Allegri, sob direção de Gabriele Vacis.
} 
chance de ser livre, Novecento decide pelo confinamento do navio? É, em síntese, a mesma pergunta do narrador:

nosso)

Ci vollero degli anni, ma alla fine, un giorno, presi il coraggio a quattro mani e glielo chiesi. Novecento, perchè Cristo non scendi, una volta, anche solo una volta, perchè non lo vai a vedere, il mondo, con gli occhi tuoi, proprio i tuoi. Perchè te ne stai su questa galera viaggiante, tu potresti startene sul tuo Pont Neuf a guardare le chiatte e tutto il resto, tu potresti sceglierti la casa più bella che c'è, puoi anche fartela a forma di nave, che ti frega?, ma te la metteresti dove vuoi, in mezzo alle tigri, magari o in Bertham Street... Diosanto non potrai continuare tutta la vita ad andare avanti e indietro come uno scemo.. tu non sei scemo, tu sei grande, e il mondo è lì, c'è solo quella fottuta scaletta da scendere, cosa sarà mai, qualche stupido gradino, Cristo, c'è tutto, alla fine dei gradini, tutto. Perchè non la fai finita e te ne scendi da qui, una volta almeno, una sola volta.

Novecento... Perchè non scendi? (BARICCO, 2002, p.34, grifo

O que nos cabe notar, aqui, é que, partindo-se do que seria previsto, Novecento propõe uma ruptura, quase como se quisesse fazer estremecer nossas concepções, sobre o que supomos ser a liberdade. E o que era previsto, esperado? Que Novecento saísse de seu habitat natural, para conhecer a realidade externa. Que ele, afinal, se libertasse. Sair do navio poderia, talvez, significar uma possibilidade de atuação, de auto-expressão e comprometimento a alguma causa real e, nesse sentido, pensaríamos no conceito de liberdade como práxis, ação transformadora do homem que produz sua própria história, na construção de uma sociedade melhor e mais justa. Porém, parece que a dimensão a que Novecento pretende nos conduzir é de outra natureza. É o que procuraremos verificar, a seguir.

Roland Barthes sustenta que "a literatura é uma trapaça salutar, uma esquiva, um logro magnífico que permite ouvir a língua fora do poder, no esplendor de uma revolução permanente" (BARTHES, 1972). Cremos que as obras escolhidas para a presente análise bem ilustram o tom lúdico da arte contemporânea, que, muitas vezes, por meio do alegórico, da fabulação, do mágico, do inverossímil, acaba levando o receptor (através do estranhamento) a se desautomatizar, suspendendo-o, conduzindo-o a profundas indagações. 
Não parece ser outro o centro das inquietações propostas por Mario Vargas LLosa, em ensaio sobre a necessidade da literatura e do romance. Ele sustenta, em síntese, que não há como pensar o mundo sem a literatura, porque só por meio dela $(\mathrm{e}$, por conseguinte, da arte) é que o ser humano consegue sair dos condicionamentos da rotina da vida real.

Segundo sua tese, apenas quando somos outros (atributo advindo da suspensão provisória em que emerge a ilusão literária) transformamo-nos em indivíduos mais intensos, mais ricos, mais complexos, mais felizes e mais lúcidos. A base da verdadeira revolução proposta pela boa literatura estaria em que a vida sonhada do romance é melhor do que a vida vivida quando estamos acordados, confinados nos rígidos limites da servidão de nossa condição humana. Nesse sentido, diz ele, a boa literatura é sempre sediciosa, não submissa, em revolta: é um desafio constante àquilo que existe. É ela, em suma, que põe radicalmente em discussão o mundo em que vivemos. (LLOSA, 2001, p.9-11, trad. nossa)

Sendo que a arte não é jamais uma finalidade em si, mas uma forma de expressão que se expande, se dirige a um receptor, em última instância, toda obra de arte é um ato de liberdade (o artista, ao criar, liberta-se, pois transcende a realidade; o receptor, ao acolher o fenômeno artístico se liberta, pois reflete, indaga, se complexifica, se engrandece). Queremos crer, com Sartre, que:

$\mathrm{O}$ ato criador é apenas um momento incompleto e abstrato da produção de uma obra; se o escritor existisse sozinho, poderia escrever quanto quisesse, e a obra enquanto objeto jamais viria à luz: só lhe restaria abandonar a pena ou cair no desespero. Mas a operação de escrever implica a de ler, como seu correlativo dialético, e esses dois atos conexos necessitam de dois agentes distintos. É o esforço conjugado do autor com o leitor que fará surgir esse objeto concreto e imaginário que é a obra do espírito. Só existe arte por e para outrem. (SARTRE, 1989, p.37)

Ao escolher, na maior parte de suas narrativas, um universo alegórico, quase mágico, suspenso, que sempre parece se abrir, diante das palavras do "Era uma vez...", Baricco delimita, a priori, seu campo de ação. Estamos adentrando as terras do "faz de conta”, em que nada, aparentemente, pode ser "tão levado a sério". Não há pretensões de qualquer tipo de verossimilhaça, até porque, nosso autor não parece querer tocar os pés no chão da realidade. Para ele, assim como para toda uma linhagem de autores-herdeiros de 
$\mathrm{Kafka}^{12}$, Joyce, Broch, etc, o realismo, enquanto expressão da realidade, no limite, pode induzir a um certo aprisionamento. Esta reflexão é muito clara em Carlos Fuentes, ao indicar que:

A prisão do realismo é que pelas suas grades só vemos o que já conhecemos. A liberdade da arte consiste, em contrapartida, em ensinar-nos o que não sabemos. O escritor e o artista não sabem: imaginam. A sua aventura consiste em dizer o que ignoram. A imaginação é o nome do conhecimento na literatura e na arte. Quem só acumula dados veristas jamais nos poderá mostrar, como Cervantes ou como Kafka, a realidade não-visível e porém tão real como a árvore, a máquina ou o corpo. (FUENTES, 2007, p. 19)

De fato, as obras de Baricco que nos propomos a analisar neste estudo são eminentemente alegóricas, centradas, espacialmente, em lugares que podem ser classificados como "não-lugares".

O navio, em que vive Novecento, é um não lugar (um universo flutuante e móvel). Assim também a Estalagem Almayer em OM é um refúgio impalpável, semelhante aos lugares dos contos de fadas, misto de sonho e fantasia. Não é diverso o reino de Quinnipak em CR, reino que, afinal, se vem a saber, havia sido criado ficcionalmente, como possível lugar de evasão e fuga da realidade.

Em todas elas, a necessidade de instaurar essa realidade não-visível, esse jogo capaz de aguçar, ao máximo, nossa capacidade imaginativa.

Interessante perceber no que toca tanto ao navio, como à Estalagem Almayer, como a Quinnipak o quanto esses universos alegóricos, em vez de servirem apenas como pano de fundo do cenário, apenas como "lugares" em que as histórias se desenvolvem, acabam por ser eleitos como verdadeiros eixos temáticos, também carregados de significação. Melhor dizendo, em alguns romances considerados "clássicos" ou de "idéias" há a descrição minuciosa dos espaços físicos, que aparecem muito mais como fundo, tal

\footnotetext{
${ }^{12}$ Milan Kundera dedica todo um capítulo de sua obra de ensaios: Os testamentos traídos, Rio de Janeiro: Nova Frontiera, trad. Maria Luiza Newlands Silveira, 1994, p. 47, para elucidar a radicalidade da revolução estética de Kafka. Vejamos o que diz: "Lembro-me de uma conversa de vinte anos atrás com Gabriel Garcia Márquez, que me disse: "Foi Kafka quem me fez compreender que podia escrever de outra maneira". Em outras palavras, isso significava: atravessando a fronteira do verossímil. Não para evadir-se do mundo real (à maneira dos românticos), mas para melhor apreendê-lo."
} 
como em algumas obras pictóricas, há a necessidade de realçar o azul de um céu claro ou o escuro de um crepúsculo. Neste caso, tudo que ocorre se passa sobre aquela tela, que serve apenas de apoio, de sustentação, representando, portanto uma nuance à margem do tema principal, sendo, assim, atemática.

Em Baricco, a escolha por representar alegoricamente cada um desses espaços jamais se dissocia das indagações que pretende propor no bojo de suas obras. O navio, a estalagem, Quinnipak são descritos apenas simbolicamente, pois pertencem à trama do narrar em si, tanto quanto cada um dos personagens e de suas respectivas vozes narrativas. Não se tratam de lugares, de espaços físicos, mas de símbolos, espaços alegóricos em que nos pautamos muito mais pelas regras do jogo do contar, da abstração que envolve esse lúdico inefável, impalpável que não quer e nem pretende se materializar. ${ }^{13}$

Analogamente ao que propõe Italo Calvino em Lezioni americane, referindo-se à fábula, parece-nos que, em Alessandro Baricco, o interesse pela alegoria não nasce da fidelidade a uma tradição étnica ou de uma certa nostalgia das histórias infantis: "è, piuttosto, un interesse stilistico e strutturale, per l'economia, il ritmo, la logica essenziale con cui sono raccontate". (CALVINO, 1990)

Consciente disso, Baricco investe nesta forma de narrar, como recurso profícuo de seu fazer literário. O que observamos, particularmente, em sua obra ficcional é que há sempre algum valor alegórico, simbólico, metafórico, que se esconde por trás das histórias e feitos mirabolantes de seus personagens.

O monólogo Novecento, recriado por Tornatore no cinema, assumiu o título "Lenda do pianista do mar", já que não se sabe ao certo se Novecento existiu ou não, se foi apenas fruto da imaginação fértil do narrador, que acreditava que, se alguém tivesse uma boa história para contar e quem quisesse ouvi-la, então nunca se daria mal ("non sarebbe mai fregato") (BARICCO, 2002, p.17).

O navio, talvez, possa representar, alegoricamente, o microcosmo do mundo, naquele ano de 1900, exatamente, na virada do século. Um universo móvel, que abrigava, a

\footnotetext{
${ }^{13}$ Ao tratar da questão dos lugares como temas, Kundera estabelece curiosa comparação entre a descrição minuciosa da cidade de Davos feita por T. Mann em A montanha mágica e, em contrapartida, a Kakania de $O$ homem sem qualidades de R. Musil, percebendo o quanto, no primeiro, tem-se o cenário como pano de fundo, ao passo que, no segundo, o lugar não é apenas descrito, mas pensado e analisado (sendo, portanto, tema), remetendo ao Império austro- húngaro, pelo viés do irônico e do ridículo. (KUNDERA, 1994, p.149).
} 
cada viagem, contingentes de pessoas, na maior parte, italianos, que migravam, em busca do sonho americano.

Que dizer, também, dos infinitos significados a que podem remeter, o trem e seu valor simbólico, associado ao de destino, em Castelli di rabbia $?^{14}$ Ou ainda, da fantástica Estalagem Almayer, em Oceano mare, para a qual se dirigem os que querem conhecer melhor o mar? Ou do mirabolante projeto de Último Parri, protagonista de Questa storia, que viveu sua vida, sonhando com uma pista para corrida de automóveis, num circuito originalíssimo, que significaria, afinal, que "bello è solo l'andare che conduce a se stesso"? (BARICCO, 2005, p.57)

Em todos os casos, nota-se que a escolha por um modo de narrar explicitamente lúdico, não é vã, mas inteiramente justificada. Ele opta por recursos estilísticos que sustentem sua crença na possibilidade de fazer prevalecer um discurso estético. Usa de certas artimanhas da linguagem, para retirar o leitor da monotonia dos registros de mera informação.

Friedrich Schiller, na obra Sobre a educação estética nos auxilia a compreender por que o impulso lúdico é fundamental no ato criativo:

O que significa, entretanto, dizer "mero jogo", quando sabemos que é o jogo e somente ele, dentre os vários estados do homem, que permite o desdobramento simultâneo e completo da natureza humana? Implícita está a afirmação de que o homem deve jogar somente com a beleza, e de que somente com a beleza ele deve jogar. Pois, para tudo sistematizarmos, o homem joga somente quando é homem no pleno sentido.(SCHILLER, 1963)

Estas idéias de Schiller fundamentam-se na teoria de Kant de que:

O prazer estético se baseia no "jogo livre" das nossas funções mentais, em face do objeto belo, e na harmonia lúdica das nossas capacidades de imaginação e entendimento. Assim, é no estado lúdico, no estado "desinteressado" ou "desinteresseiro" (isto é, sem interesse na existência material do objeto) que o homem supera as dilacerações da vida interessada.(KANT apud SCHILLER, 1963)

\footnotetext{
${ }^{14}$ A propósito, ver o capítulo 3 deste nosso estudo.
} 
Ao optar por formas de narrar eminentemente lúdicas, a ficção de Baricco parece nos fazer refletir, por meio de um estado "desinteresseiro", sobre as estruturas pragmáticas, rígidas, utilitárias do discurso que mantém a língua a favor de um poderoso e alienante sistema consumista, em que tudo deve ser usado com finalidades altamente produtivas, que atendam às necessidades do mercado, favorecendo o sistema massificado e globalizado de produção.

Nesse sentido, o personagem Novecento, que não se adapta ao sistema, é plenamente justificado. Não há lugar, para ele, na sociedade tal como se apresenta.

De fato, concebemos Novecento como aquele que "confuta o utilitarismo"15, não como o que se aliena, pactuando dele. Em nossa opinião, ele reage contra o sistema, ao reafirmar sua escolha por permanecer no navio.

Notamos nessa inadequação de Novecento, certa identificação com o que alguns filósofos como Kierkegaard, Nietzche, Wittgenstein proclamaram como sendo o "absurdo dos sistemas". Na verdade, a refutação aos sistemas traduz, de certa forma, um protesto contra a Lei, contra o Poder em si.

Barthes, seguindo a tradição cética francesa desde Montaigne a Gide, também faz sua denúncia, a partir do que chama de "esclerose dos sistemas". ${ }^{16}$

Dentre as reflexões apregoadas por esses tantos filósofos, chama-nos a atenção, em particular, as de Kierkgaard. Partindo do pressuposto de que a vida é um fluxo caótico de experiências, valores, solicitações, desejos, medos, imagens, etc, ele chega à conclusão de que se faz necessário estabelecer alguns pontos fixos, que acabarão implicando na noção de que a vida é, necessariamente, uma série de escolhas. E a escolha seria o momento culminante da responsabilidade moral.

Nesse sentido, em Kierkgaard, não se podem encontrar meios-termos. Este fato torna mais dramático o problema da existência. E, então, ele conclui que um sistema é sempre um castelo de gigantes em que o individual não parece caber.

\footnotetext{
${ }^{15}$ Essa expressão foi usada por Frank Raymond Leavis em La grande mutazione (1940-68, trad. it., Milano, Mursia, 1968, pp.257 apud BERARDINELLI, A.: Não incentivem o romance. São Paulo: Humanitas, 2007, p.95.

${ }^{16}$ Ver, a propósito, interessante estudo sobre Barthes e a "esclerose dos sistemas" em SONTAG, S. Questão de ênfase. São Paulo: Cia das Letras, 2005, p.96-97.
} 
Em resumo, de acordo com o eminente filósofo, nas enormes construções que representam os sistemas, onde existiria o espaço do indivíduo ${ }^{17}$

Novecento não caberia no sistema. Desde o início de sua história, ele é avisado pelo pai adotivo para fugir da Lei, do capitão do navio, dos que o quisessem levá-lo a um orfanato, a fim de inseri-lo na sociedade, a fim de "regularizá-lo". Assim, percebemos que a escolha de Novecento é a da resistência e não a da resignação.

A escolha de Novecento é a da esthesis, a da arte, em contraposição ao pragmatismo dos que vivem, de certa forma, alienados na "sociedade do espetáculo", em que tudo se reduz ao consumo e ao imediatismo das relações. ${ }^{18}$

Queremos ainda crer, com Adorno (1993), que o ideal artístico de representação da vida verdadeira (que ele denomina "estético") deve se contrapor e resistir às manipulações despolitizadoras da sociedade que servem a uma "indústria cultural" (que expande para a vida os valores distorcidos de uma super valorização do capital). Uma sociedade que produz alienação trabalha em sentido oposto ao ideal libertário da autonomia da obra de arte, enquanto "atividade emancipadora". Por isso:

Não basta à literatura fazer a ilustração da sua época. Não basta observar e descrever a realidade. É preciso ir além. Forma e conteúdo devem estar integrados. A forma já é a idéia, o que permite que o relato de uma pacata dona de casa seja eventualmente muito mais forte e violento do que as memórias do mais implacável dos matadores. É isso o que há de mais surpreendente e libertário em literatura.(CARVALHO, 2003)

Percebemos, tanto em Novecento de Baricco, quanto no conto La libertà de Buzzati, já citado como ponto de interseção da obra analisada, o quanto ambos se prestam a ilustrar esta espécie de "libertária surpresa". É exatamente no modo fantástico de contar as histórias, enfim, de enunciá-las que se presentifica a urgência (evidente em nossos dias), de privilegiar um discurso fundamentalmente estético, capaz de chamar o homem a uma

\footnotetext{
${ }^{17}$ Esta nossa referência a Kierkgaard foi possível por meio das anotações de aulas ministradas pelo crítico Alfonso Berardinelli, quando esteve na USP, em novembro de 2005. Ele citou Kierkgaard, a partir da análise que fazia da obra de Luckáks, em Italiano: "Opera sulla forma del saggio".

${ }_{18}$ Sobre a chamada "Sociedade do espetáculo" ver interessante estudo de G. DEBORD. A sociedade do espetáculo (DEBORD, 2007)
} 
reflexão mais sentida, que não lhe permita cair nas falsas armadilhas do pensar. Deveríamos, talvez, indagar se tais características emancipatórias, em última instância, não estariam presentes em toda criação literária moderna.

Sabemos que toda obra literária, a partir da transformação da realidade, pressupõe a necessidade do jogo, do estranhamento, de uma certa desautomatização do pensar que, de alguma maneira, induzam a uma lúdica travessia para a liberdade. Entretanto, queremos, nesta pesquisa, apenas enfatizar que, ao escolherem determinados recursos narrativos (e esta consciência parece ser uma das características da ação criadora contemporânea), tanto Baricco, quanto Buzzati tratam de questões absolutamente sérias, que tocam a complexa condição humana e podem ser como que guias, para o que pretendemos demonstrar.

Então, o traço desinteressado, descompromissado da fabulação, do fantástico, do alegórico, enfim, do tom de faz de conta, como uma das inúmeras faces do lúdico, potencializa a atividade emancipatória e epifânica da obra de arte literária, capaz de conduzir a uma verdadeira libertação. É, portanto, nesse modo, aparentemente ingênuo de contar, que se opera um estremecimento de nossa visão de mundo, "estendendo a conquista do ser”. (KUNDERA apud MAFFEI, 1988, p.315-27)

De fato, o conto fabulesco de Buzzati, em resumo, trata da história de um homem que compra, em uma feira, um peixe vermelho dentro de um pequeno aquário de vidro. Preocupado com o animalzinho, pensando que ele pudesse estar muito confinado e insatisfeito naquela casa tão estreita, decide construir-lhe uma comprida, larga e tépida banheira. Ao removê-lo para o novo espaço, o homem toma, até mesmo, o cuidado de mantê-lo dentro do aquário, a fim de que não sofresse com a brusca mudança, a fim de que fosse se aclimatando aos poucos ao novo ambiente. Para seu espanto, o que ocorre, estranhamente, é que o peixe, logo ao início, sai de sua casinha, nada pelas novas e vastas águas, mas subitamente retorna ao ponto de partida, sem sair mais. E esse seu comportamento vai se manter ao longo dos dias subseqüentes. Indignado, o homem o interpela, dizendo-lhe que havia gastado um bom tanto para the dar o melhor e ele, agindo daquele modo, dava-lhe sinais de ingratidão e indiferença. A pergunta crucial, feita pelo homem ao peixe é a seguinte: por que, se mesmo podendo nadar mais livremente, em um espaço melhor e mais amplo, ele optara por permanecer no antigo confinamento? 
O peixe lhe responderá que o importante não é a liberdade em si, mas o uso que se faz dela. E ainda acrescenta que se, por acaso, ele se esquecesse do aquário e passasse a nadar na grande banheira, em pouco tempo, provavelmente, estaria insatisfeito e nem mesmo o novo espaço lhe poderia satisfazer.

Enfim, o que o animal propõe em sua fala é um real questionamento sobre o que os seres humanos pensam sobre "ser livre" e o quanto há de "falta de inteligência" em suas teorias. (BUZZATI, 1963)

Agora, tentando aproximar as duas narrativas, verificamos que um dos recursos utilizados centralmente, em ambas, é o da ruptura, o da total quebra de expectativa, que induz à pergunta: por que, tanto o pianista, quanto o peixe vermelho, não se libertam, se tinham todas as condições para tanto? Outro recurso, certamente, como já adiantamos, é o dessa escolha pela fabulação, voltada para a oralidade. Ambas são histórias propícias a serem narradas em voz alta.

Vejamos. Em Novecento, no prefácio, tomamos conhecimento de que o autor escreveu um texto para ser representado, ou, ao menos, lido em voz alta.

O tom do faz de conta, da necessidade de reiterar a proposta de um universo mágico, se revela em todo o livro. O narrador interage com o leitor, provocando-o, dizendo de modo informal e espontâneo que tudo o que ele conta parece muito difícil de acreditar, porém, acreditem ou não (ele avisa) "o que eu lhes conto é verdade". Citemos, a título ilustrativo, o seguinte trecho:

Credetemi, non ne troverete altre di navi così: forse, se cercherete per anni ritroreverete un capitano claustrofobico, un timoniere cieco, un marconista balbuziente, un dottore dal nome impronunciabile, tutti sulla stessa nave, senza cucine. Può darsi. Ma quel che non vi succederà più, potete giurarci, è di stare li seduti col culo su dieci centrimetri di poltrona e centinaia di metri d'acqua, nel cuore dell'Oceano, con davanti agli occhi il miracolo, e nelle orecchie la meraviglia, e nei piedi il ritmo e nel cuore il sound dell'unica, inimitabile, infinita, ATLANTIC JAZZ BAAAAND!!!!! (BARICCO, 2002, p.16) 
Em Buzzati, o tom da narrativa, muito informal, a aparente "simplicidade" com que a história é narrada, a escolha de alguns tempos verbais e expressões idiomáticas (modi di dire) e, sobretudo, o diálogo entre o homem indignado e o peixe irreverente, todas estas estratégias da enunciação colaboram para criar uma estrutura, um corpus, em que a forma e o conteúdo, indissociáveis, conseguem servir a uma finalidade maior, aquela de toda fábula, que é a de transcender a categoria da "historinha" para a de um ensinamento, a de uma reflexão.

Servem como exemplos, os seguintes fragmentos: "Tempo fa al mercato, comprai un pesce $\operatorname{rosso}(\ldots)$ "; “(...) vederlo dar di muso continuamente contro il vetro (...)”; “(...) restai di sasso (...)"; "(...)Capriccio di pesce! io pensai (...)"; "Tanto che io persi la pazienza e gli parlai: Caro pesce...tu passi il segno. Ho speso un mucchio di quattrini... Giuro che mi fai cadere le braccia!!(...)"(BUZZATI, 1963, grifo nossso)

Nos dois casos, vale ressaltar a crença na força literária da narrativa, que se aproxima da oralidade, o poder das histórias que se contam, capazes de alargar a dimensão do viver. Walter Benjamin, no texto "O narrador" afirma que:

As melhores narrativas escritas são as que menos se distinguem das histórias orais, contadas por inúmeros narradores anônimos. Estas apresentam, em latência, um ensinamento moral, uma sugestão prática, um provérbio ou norma de vida. Ou seja, o narrador é o que sabe dar conselhos e o conselho corresponde à sabedoria, porque ele retira da experiência aquilo que conta, tendo sempre suas raízes no povo, nas camadas artesanais. (BENJAMIN, 1980, p.69)

É Novecento quem nos ensina, já nas primeiras páginas: "Non sei fregato veramente finché hai da parte una buona sotria e qualcuno a cui raccontarla".("Você não se dará mal, desde que tenha uma boa história e alguém a quem contá-la”.) (BARICCO, 2002, p.17, trad. nossa)

É o peixe vermelho quem nos alerta contra a pobreza de nossa percepção sobre o que vem a ser a liberdade.

Nos dois casos, há como tema central a ser discutido, o da relativização do conceito de liberdade. Interessante perceber o quanto o que se estabelece como questão 
argumentativa parece estar em consonância, ao menos em Baricco (autor aqui a ser analisado), com a séria discussão sobre o resgate da liberdade, no contexto da sociedade contemporânea massificada, a partir da revitalização de um discurso primordialmente estético.

Vejamos, então o que aquele menino sem limites de Novecento e o peixe atrevidamente vermelho de La libertà têm a nos contar.

\subsection{Entendendo o jogo: um menino sem limites e um peixe atrevidamente vermelho}

Desde muito cedo, o pequeno Novecento aprende a conviver com um universo em movimento: sua percepção da realidade estará simbolicamente ligada à constante oscilação do oceano. Vale, aqui, perceber que o nome de um personagem tão "sui generis" carrega, de saída, um instigante significado: Danny Boodmann T. D. Lemon Novecento. Temos, nesse nome-frasal, uma síntese do que a América passa a representar para uma Itália pobre e miserável (o ideal de "fare l'America"), com todas as consequiências que daí advieram, especialmente na virada do século, ou seja, no especial ano de 1900.

O que a América representou, a princípio, em particular, para o pobre imigrante que, dentro dos navios, abarrotados de gente, singrava mares, em busca de melhores condições de vida, pode ser sintetizada na palavra "esperança". Não faltam, na literatura, belas obras que abordem, de modo profundo e comovido, como o imigrante italiano vivenciou (com o tanto de contradições e sofrimentos que isso pudesse causar) o chamado "sonho americano".

No livro de Baricco, a primeira página, a que "abre" o monólogo, refere-se à aparição dela, da América, como algo de encantado, maravilhoso, no sentido da euforia associada, ao mesmo tempo, à dúvida e ao medo do novo (aquele que primeiro a via, ficava como que extasiado e anunciava, com os pulmões cheios de ar, como marinheiro que, antes de todos, avistasse terra: América!) ${ }^{19}$ Interessante notar que essa primeira visão da

\footnotetext{
${ }^{19}$ Gostaríamos de lembrar, aqui, de uma cena do filme "Buon giorno Babilonia" dos irmãos Taviani, em que os dois irmãos Andrea e Nicola partem para a América, a fim de buscarem melhores condições de vida. Ao avistarem-na, da pequena escotilha do navio, após a longa e desafiante viagem, a imagem que se lhes aparece é a da cidade de N.York, associada a uma imagem que os dois trazem da infância: a aparição, diante dos olhos extasiados dos dois meninos, da grande e luminosa árvore de Natal (preparada em sua casa, na cidade natal na Itália, no fim de ano). O que se estabelece, assim é a comparação, por meio de imagens, do significado da
} 
América, coincidindo com a abertura da obra, parece querer enfatizar o quanto havia de expectativas geradas, em torno do simples nome América. Veja-se o seguinte:

Succedeva sempre che a un certo punto uno alzava la testa... e la vedeva. è una cosa difficile da capire. Voglio dire... Ci stavamo in più di mille, su quella nave, tra ricconi in viaggio, e emigranti, e gente strana, e noi... Eppure c'era sempre uno, uno solo, che per primo... la vedeva. Magari era li che stava mangiando, o passeggiando, semplicemente, sul ponte... magari era li che si stava aggiustando i pantaloni... alzava la testa un attimo, buttava un occhio verso il mare... e la vedeva. Allora se inchiodava, li dov'era gli partiva il cuore a mille, e, sempre, tutte le maledette vlte, giuro, sempre si girava cerso di noi, verso la nave, verso tutti, e gridava (piano e lentamente): l'America. Poi rimaneva li, immobile come se avesse dovuto entrare in una fotografia, con la faccia di uno che l'aveva fatta lui, l'America. (BARICCO, 2002, p.11, grifo nosso)

Essa primeira impressão, tão fascinante e idealizada, vai marcando os passageiros do Virginia, que depois de a terem visto, deverão necessariamente desembarcar e pisar em terra firme, encarando todos os desafios do novo mundo.

Numa leitura mais crítica, poderíamos, talvez, reconhecer na atitude inesperada de Novecento em não querer sair do navio, uma espécie de resistência aos falsos e ilusórios chamados de uma América "salvadora", "mítica", "regeneradora", em que todos os sonhos humanos seriam passíveis de concretização. De fato, no final do livro, ao tentar explicar ao amigo (transtornado com a sua decisão) os motivos que determinaram a sua escolha, ele não poupa argumentos, a fim de questionar as falsas aparências e traiçoeiros chamados, do tal mundo, além do convés. Ao dizer que o assusta tudo aquilo que é sem limite, que é grande demais, bom demais, espetacular demais, em certa medida, ele estaria, também, a dizer: "Cuidado com essa idéia distorcida de paraíso terrestre: América!"

primeira visão da América. Esta visão primeira da América, com tudo que carrega de grandioso e surpreendente, seria comparada à mesma visão que os dois meninos tinham como maravilhosa, diante da exuberante árvore de Natal da infância. Nos dois casos, a mesma surpresa, o mesmo êxtase, a mesma sensação de respiração suspensa dos que primeiro viam a América, em Novecento de Baricco. 
No fundo, Novecento questiona a tal esperança cor de rosa, estampada no olhar dos que viam a América, pela primeira vez e se inebriavam, diante daquela visão magistral. Ele questiona, criticamente, a que tipo de liberdade, essa falsa ilusão poderia levar.

Ao salvar a criancinha deixada num caixote (em que as inscrições T.D. Lemon representariam, metonimicamente, a Itália meridional, reconhecida como produtora de limões, e, agora, tão empobrecida, a ponto de não conseguir sustentar seus próprios filhos, abandonando-os à própria sorte), o negro americano Danny Boodmann, confere sentido à sua própria existência. O menino "levará adiante" seu nome e, inclusive, ascenderá socialmente, depois de sua morte, infringindo as normas pré-estabelecidas, a de que, por exemplo, os operários não deveriam subir aos espaços nobres do navio. O pequeno Novecento sairá do espaço subalterno das galés (em que só ficavam os carvoeiros e operadores que, efetivamente, faziam com que a máquina navegasse) e passará a transitar pelos espaços da primeira classe, sendo reconhecido e valorizado por meio daquilo que o torna um indivíduo: a música, a sua arte.

Interessa notar que, nessa justaposição do nome, nessa fusão América- Itália ( e tudo o mais a que isso possa remeter), o acréscimo "Novecento" acrescenta toda euforia, todo glamour, toda ebulição de um novo tempo que, paradoxalmente, antecipará algumas das fases mais patéticas e angustiantes da história da humanidade, como, por exemplo, as duas grandes guerras e a as sangrentas lutas operárias. Nosso protagonista, assim, já no nome, preanunciará essa profunda e densa contradição: a de representar, simbolicamente, a porta de entrada para o século XX.

Porém, por mais que esse século possa remeter à idéia de grandes contingentes humanos em movimento, à imagem das massas migratórias, massas operárias, enfim à massificação do ser humano, cada vez mais diluído e despersonalizado, o narrador nos alerta que Novecento não nascerá para ser mais um número, um a mais na multidão. É o que responderá seu pai americano, quando lhe perguntarem sobre o nome que escolhera para o filho adotivo:

- É un'idea buona, Sam, L'ho trovato nel primo anno di questo nuovo, fottutissimo secolo, no?Io lo chiamerò Novecento.

- Novecento?

- Novecento. 
- Ma è un numero!

- Era un numero:adesso è un nome. (BARICCO, 2002, p.21)

Em todo esse longo aprendizado, em seu aparentemente estreito universo movediço, o que protege e salva o menino-homem pianista de todas as dúvidas e aflições é a música, a arte.

Aliás, é diante da primeira grande dor (da perda do pai) que o menino vai aprendendo - ouvindo os sons que fazem fundo à cerimônia daquele adeus, enquanto jogam o corpo de seu pai morto no mar - a sublimar as dilacerações de seu espírito, ainda criança. Percebe que "aquilo" o conforta, transcende-o, liberta-o. Esta primeira impressão é tão significativa, que tem a força de impulsioná-lo, tal como a força impetuosa das águas daquele oceano, quase como que de arrancá-lo do mundo dos porões, do carvão, conduzindo-o ao salão mais nobre do navio, numa total superação do medo do novo, do proibido. Às escondidas, num surto de felicidade clandestina, descobre o piano e, completamente atraído pelo instrumento, como se desde sempre o conhecesse, começa a tocar...

É comovente e, ao mesmo tempo irônica, a descrição que, no livro, encontramos sobre o aparecimento de Novecento, diante dos demais "habitantes" daquele navio. Neste momento preciso, o menino nasce para o mundo, além das galés e subverte, por meio de sua música, os regulamentos, as normas vigentes até então:

Suonava non so che diavolo di musica, ma piccola e... bella. Non c'era trucco, era proprio lui a suonare, le sue mani, su quei tasti, Dio sa come. E bisognava sentire cosa gli veniva fuori...

- Come si chiama?

- Novecento.

- Non la canzone, il bambino.

- Novecento.

- Come la canzone?

Era quel genere di conversazione che un comandante non può sostenere più di quattro o cinque battute. Sopratutto quando ha appena scoperto che un bambino che credeva morto non solo era vivo ma, nel frattempo, aveva anche imparato a suonare il pianoforte.... Avrebbe voluto dire molte cose, in quel momento, e tra le altre "Dove cazzo hai imparato?" o anche "Dove diavolo ti eri nascosto?". Però, come tanti uomini abituati a vivere in divisa, 
aveva finito per pensare, anche, in divisa. Così quel che disse fu: "Novecento, tutto questo è assolutamente contrario al regolamento."

Novecento smise di suonare. Era un ragazzino di poche parole e di grande capacità di apprendimento. Guardò con dolcezza il comandante e disse: “ In cullo il regolamento!”(BARICCO, 2002, p. 24-25)

Tal qual o menino, que se anuncia "sem limites", porque prepara, de início, uma ruptura, uma subversão ao que estava posto (no caso do texto de Baricco, através da arte), também, o aparentemente frágil peixe vermelho do conto de Buzzati, ao dialogar com seu dono assume, de modo arguto e provocante, uma postura que pretende "revolucionar" o conceito de liberdade, em que, o homem, limitado em sua percepção, acreditava:

O uomo, come sei poco inteligente e perdona la sincerità. Che strana idea della libertà tu hai! Non è l'uso della libertà che importa, anzi esso è di solito una cosa insulsa e volgarissima. Ciò che importa è la possibilità di usarne. Qui è il suo sapore più squisito. Io amo stare in questo vaso, che è così intimo e raccolto, propizio alle meditazioni solitarie. Ma so che quando voglio posso uscirne e fare lunghi viaggi nella vasca (per la quale tra parentesi ti sono estremamente grato) (BUZZATI, 1963)

Em sua atitude irreverente e muito irônica, o peixe propõe a relativização do conceito de liberdade, subvertendo a crença do senso comum, sacudindo, com sutis pontos interrogativos, a visão estática e alienada, inerente a todo tipo de raciocínio superficial e pouco indagador.

Nas duas situações, há uma subversão das "regras" do jogo social, das máscaras, da manipulação, implícitas em regulamentos impositivos e autoritários.

O pianista, por meio da criação estética, de seu impulso lúdico, rompe com as rígidas regras da alienação de uma sociedade massificada, forjando a sua liberdade, criando o seu indivíduo, libertando-se da pena a que todos estão condenados, pensando estarem livres, quando, na verdade, estão “coisificados” (ADORNO in LETCHE, 2002, p.200). 
Novecento cria sua liberdade como artista. O peixe cria sua liberdade como pensador, filósofo, que trabalha com o jogo do pensar. Daí ser-lhe fundamental contrapor, ao conceito do ilimitado, o limite, da liberdade como possibilidade que não abdica da consciência do cárcere.

Nicola Abbagnano, em seu Dicionário de Filosofia, afirma:

Hoje, assim como nos tempos em que a noção no mundo moderno foi formulada pela primeira vez, a Liberdade é uma questão de medida, de condições e de limites, e isso em qualquer campo, desde metafísico e psicológico ao até econômico e político. Hoje se destaca o fato de que a Liberdade humana é "situada, enquadrada no real, uma liberdade sob condição, uma liberdade relativa" (Gurvitch, "Détermismes sociaux et liberté humaine, 1995, p.81). Expressa-se por vezes esse conceito dizendo que a Liberdade não é uma escolha, mas uma "possibilidade de escolha", ou seja, uma escolha que, se feita, poderá ser sempre repetida em determinada situação. (ABBAGNANO, 2003, p.612-13)

Ora, não parece ser outra, a observação do peixe, ao refletir que o importante, mais que o uso da liberdade é a possibilidade de usá-la. Essa sensação, ele obtém, através da contraposição dos limites do cárcere (que já conhece), tendo a consciência de que poderá dele sair, quando bem entender. A possibilidade de liberdade existe (e vem daí a alegria de desfrutá-la), a partir das "medidas” estreitas do que era cárcere e agora não é mais.

Assim, não há real confinamento, quando se alargam as percepções do ser; não há espaços estreitos, quando o olhar se expande; não há prisão, quando deixamos de pensar “in divisa" e passamos a explorar nossas potencialidades sem limites.

Haveria ainda a lembrar, quanto às possíveis indagações sobre o conceito de liberdade, que o que Novecento faz, ou seja, o modo como age se ampara perfeitamente nas teorias do livre arbítrio. Existimos e somos determinados por nossa livre capacidade de escolha:estamos, de certa forma, condenados a escolher.

Fernando Savater, em um estudo sobre ética, desenvolve interessante reflexão sobre nosso livre arbítrio. De fato, ele parte do pressuposto de que, se, por um lado, a natureza se pauta por uma série de determinações pré-estabelecidas, que são irrefutáveis e 
imutáveis, no mundo dos homens, há toda uma relativização de conceitos, já que somos responsáveis por nossas escolhas.

Diz ele que, por exemplo, um castor não costuma construir colméias, assim como abelhas não costumam construir diques nos rios.

Analogamente, algumas formigas africanas, conhecidas como termitas, por possuírem uma couraça muito frágil, constroem verdadeiras fortalezas para se protegerem. Mas, mesmo assim, quando do ataque de outras predadoras mais fortes, algumas eleitas serão as que deverão, obrigatoriamente, tentar distrair as inimigas, a fim de que as outras ganhem tempo para refazer o formigueiro. Inevitavelmente, em decorrência desse ato heróico, acabarão ficando do lado de fora e morrerão.

Segundo Savater, estas formigas "soldados" não têm escolha. Cabe-lhes o papel de heroínas e isso está já determinado.

Em compensação, comparando esse ato supostamente heróico das formigas ao ato heróico de Heitor, que defendeu Tróia do grande e temível guerreiro Aquiles, o filósofo sustenta que, nesse caso, sim, se pode falar em verdadeiro heroísmo da parte de Heitor, pois sua decisão envolveu uma escolha.

Melhor dizendo, ao passo que as formigas não têm outra escolha, Heitor poderia ter escolhido outra opção que não aquela de oferecer sua coragem, na defesa de seus concidadãos. Poderia, inclusive, para salvar a própria pele, ter escolhido o desdém dos que passariam a vê-lo como covarde, caso não lutasse. Poderia, enfim, encontrar outros subterfúgios que pudessem livrá-lo daquela difícil batalha. Mas ele escolheu lutar por Tróia.

Assim, de acordo com essa teorização, somos responsáveis por nossas escolhas e a capacidade do livre arbítrio é também, para além de uma atribuição humana, característica que nos constitui e diferencia dos demais seres vivos. (SAVATER, 1992)

Em nossa opinião, exatamente por querer resistir ao sistema que aliena e aprisiona, Novecento encarna a figura do personagem que não se deixa reduzir pela realidade. Sua escolha, embora aparente insensatez (porque, no limite, implica a do suicídio) é a mais difícil e coerente com o que ele nos ensina. Daí porque percebemos em sua atitude algo de heróico, de reação e não de covardia ou aparente comodismo. 
Não poderíamos, também, deixar de mencionar o personagem da Divina Comédia Catone Uticense (Catão de Útica), famoso legista da república da Roma antiga, que, tomou o partido de Pompeu contra César e se suicidou quando este venceu, para não sobreviver à perda das liberdades republicanas.

A princípio, segundo a ética de princípios morais e religiosos que nortearam a famosa obra de Dante Alighieri, este personagem deveria estar no Inferno, por ter sido, em vida, pagão e suicida. Entretanto, ele aparecerá como guardião da entrada do Purgatório.(ALIGHIERI, 2004, p.13-18) Mesmo suicida, aqui, o que parece ser privilegiada é a atitude heróica de Catão, que por não se adequar à corrupção política do sistema, contrária a seus princípios, escolhe, num ato de legítima liberdade, dar cabo da própria vida.

Em situação análoga à mencionada anteriormente quanto a Heitor, sua escolha, naquele contexto, foi tomada como heróica.

\subsection{O jogo da música: aprendendo a dançar O jogo transparente do vidro: espelhos da alma}

Interessante a passagem em que, no monólogo de Baricco, se anuncia a primeira tempestade em alto mar. Agora, Novecento, já adulto, convida seu amigo, o narrador, a acompanhá-lo, num verdadeiro "baile", em que os dois, ao som do piano (e com o piano) deslizarão pelo imenso piso de mármore do requintado salão do Virginia.

O céu escurece e a amedrontadora tempestade se precipita, as águas se agitam revoltosas. Há o medo absoluto, a total imobilização que nos vem das situações de pânico e a humilhante constatação de que "estamos à deriva", qual embarcação perdida no oceano, em meio ao temporal... Nada a fazer... Apenas esperar que passe... A descrição da borrasca é toda feita em versos e a força poética é de uma beleza e vitalidade, que vale a pena transcrever.

Já sabemos que Baricco pretendia que sua história fosse recitada. Daí porque, colaborarão, na tessitura do poema, a seleção lexical, o ritmo, as rimas, as pausas, as cesuras, as repetições eminentemente sonoras. Há, com efeito, uma "construção" do medo 
absoluto, em todas as suas nuances, o batimento cardíaco acelerado, a respiração ofegante, diante das ondas rebeldes do grande, temível mar, "che si sveglia" (que acorda). Vejamos:

(in audio rumore di burrasca...)

Il mare si è svegliato/il mare ha deragliato/scoppia l'acqua contro il cielo/scoppia/sciacqua/stacca al vento nubi e stelle/furibondo/ si scatena fino a quano/ non si sa/ dura un giorno/ finirà/ mamma questo/ non l'avevi detto mamma/ ninna nanna/ ti culla il mare/ ti culla un corno/ furibondo/tutt'intorno/ schiuma e strazio/ pazzo il mare/ fino adove puoi vedere/ solo nero/ e muri neri/ e mulinelli/ e muti tutti/ ad aspettare/ che la smetta/ e naufragare/ questo mamma non lo voglio fare/ voglio l'acqua che riposa/ che ti specchia/ ferma/ questi/ muri/ assurdi/ d'acqua/ giù a franare/ e 'sto rumore/

rivoglio l'acqua che sapevi tu

rivoglio il mare

silenzio

luce

e pesci volanti

sopra

a volare. (BARICCO, 2002, p.26)

Os primeiros versos, recitados em seqüência continuada, traduzem a agitação do despertar furioso do mar. O eu poético, então habituado aos embalos suaves de um mar calmo, de uma cantiga de ninar acolhedora, comparada ao berço, ao aconchego, ao útero materno complacente, em que o ambiente aquático era de tranqüilidade e proteção, não consegue compreender o que se passa e evocando a imagem materna, amedrontado, interpela a mãe, chama-a, como se ela não o tivesse alertado, preparado para o desafio da tempestade. Muito adequada, na construção sonoro-imagética-sinestésica desse temporal em alto mar, a manutenção do ritmo dos versos, ao final. Antes ágeis, impetuosos, aos poucos, vão revelando um cansaço, um extenuar (conseqüente ao susto e ao pavor), que 
ralenta as falas daquele eu que vai se acalmando, por meio da lembrança afável e amena de outro mar, já conhecido, de uma "água que sabia a ti" (que tinha o gosto da mãe), que era, assim como, no útero, silêncio e luz...

Para superar o medo da tormenta, o pianista desacorrenta o piano (que estava preso ao chão) e tocando suas teclas, num gesto loucamente lúdico, movimenta-se com ele, como se o guiasse: dança. Neste ritual simbólico, ele faz com que sua música, acompanhando aquela que vem do mar, liberte-o (bem como a seu amigo) da angústia opressora, inerente à situações com as quais não se sabe lidar.

A arte, mais uma vez, é a grande saída, a única via de escape, diante dos males do viver. Claro, avisa-nos o narrador, provocando nossa curiosidade, jogando com a idéia do inverossímil: ninguém precisa acreditar naquela "dança com o oceano". Nem ele mesmo, caso lhe contassem algo semelhante, acreditaria, mas foi, de fato, assim:

Ora, nessuno è costretto a crederlo, e io, a essere precisi, non ci crederei mai se me lo raccontassero, ma la verità dei fatti è che quel pianoforte incominciò a scivolare, sul legno della sala da ballo, e noi dietro a lui, con Novecento che suonava, e on staccava lo sguardo dai tasti, sembrava altrove, e il piano seguiva le onde e andava e tornava, e si girava su se stesso.... mentre volteggiavamo tra i tavoli, sfiorando lampadari e poltrone, io capii che in quel momento, quel che stavamo facendo, quel che davvero stavamo facendo, era danzare con l'Oceano, noi e lui, ballerini pazzi e perfetti, stretti in un torbido valzer, sul dorato parquet della notte. Oh yes...(BARICCO, 2002, p.29-30)

Em outro texto, o peixe vermelho de Buzzati também "brinca" com o universo aquático circundante, tentando melhor conhecê-lo. O homem não compreende porque ele, depois de "scorribandare da una parte all'altra della vasca, entusiasta della inaspettata libertà", opta por ficar quieto "dondolandosi a mezz'acqua", "ne dando più di testa, come prima contro la parete". (BUZZATI, 1963)

Evidencia-se, neste caso, a exploração (embora temerosa) do novo espaço, uma cuidadosa atitude de percepção, a necessidade de perscrutar, aguçando os sentidos, para apreender a nova realidade. Embora saia, vez ou outra, para nadar fora de seu aquário, o 
peixe precisa voltar para casa. A parede de vidro contra a qual ele "dà di muso" de modo contínuo, por ser transparente, permite-lhe "ver" muito além.

Há, nesse sentido, um apelo explícito à necessidade do ser de voltar-se a si mesmo, aos lugares mais escondidos, mais recônditos, estreitos, num profundo mergulho existencial. É o peixe quem nos avisa: "io amo stare in questo vaso, che è così intimo e raccolto, propizio alle meditazioni solitarie...”(BUZZATI, 1963)

O menino Novecento e, também, o adulto, sempre que o sofrimento parecia querer flagrar-lhe, enfraquecendo-lhe o espírito, se "recolhia", voltava ao fundo do navio, ao seu esconderijo mais íntimo (que só ele conhecia) e lá, com a face colada à janelinha de vidro minúscula do porão, via, por meio daquela película transparente, toda a imensidão do mar. E ali se deixava ficar, qual feto protegido, no grande ventre materno, sem dizer palavra, sem noção do tempo ou de qualquer chamado, o olhar perdido na direção das águas, que, como um colo ondulante, o embalavam. Ninguém compreendia o que poderia estar acontecendo.

O que se pode apreender desta simbologia? Talvez, buscar a aceitação da pausa, como característica inerente ao movimento, das oscilações do ser como naturais ao homem, recuperando um silenciar necessário, em boa medida, protegidos pelo vidro, que é um anteparo, por meio do qual continuamos a ver e talvez, a ver melhor, porque guardando certa distância dos fatos e da realidade.

Embora, numa primeira leitura, o vidro pudesse sugerir algo relacionado à opressão, porque estaria confinando o peixe e o pianista, aos poucos, convencemo-nos, nesse contexto, de sua importante função protetora e, ao mesmo tempo, reveladora, já que é possível ver, infinitamente, através dele. Tal anteparo permite que os personagens se sintam seguros, em suas respectivas moradas interiores (o que é sempre necessário) e assim, mergulhem dentro de si mesmos, alargando suas visões de mundo, num contínuo e perscrutador exercício do olhar. Esse detalhe nos conduz à percepção ilimitada das diferentes, inexauríveis possibilidades de ver, ainda que por janelas aparentemente estreitas.

\subsection{O inquietante jogo do olhar: uma grande viagem}

Como era possível, pergunta o narrador, que Novecento conhecesse tantos lugares, descrevendo-os, nos mínimos detalhes, sem nunca ter saído do navio? A 
simbologia deste pequeno/grande mundo, do limitado/ilimitado de um universo infinito que se descortina, ainda que a partir de uma simples casca de noz, faz-nos lembrar do conto de Borges, "O Aleph". Esta primeira letra do alfabeto hebraico refere-se a uma "pequena esfera furta-cor, de quase intolerável fulgor", uma espécie de instrumento mágico minúsculo que permite ao narrador-protagonista, ver o "inconcebível universo". A experiência do inesperado, aliada a do deslumbramento, quase como um susto, arrebata-o por inteiro: "O diâmetro do Aleph seria de dois ou três centímetros, mas o espaço cósmico estava aí, sem diminuição de tamanho. Cada coisa (o cristal do espelho, digamos) era infinitas coisas, porque eu a via claramente de todos os pontos do universo".(BORGES, 1989, p. 170-1)

Interessante como, de alguma forma, os limites do Virgínia, que, a princípio, poderiam cercear a visão de Novecento, em vez de confiná-la, a amplia.

Analogamente, a partir de uma esfera tão diminuta, o personagem de Borges enxerga, quase ao limite do fantástico, um universo que jamais termina, daí a ser, praticamente, inconcebível. Em ambos, a afirmação de que a dimensão do espaço (embora, aparentemente, restrita e limitadora) não tem, necessariamente, que aprisionar o que os olhos são capazes de perceber.

Novecento imaginava... Mais do que isso era dotado da sensibilidade de apreender o mundo, por meio das pessoas que passavam por ele. E o mundo, com os seus mais diferentes tipos humanos, desfilou, diante de seu olhar atento e curioso, ainda que dentro das limitações daquele universo movente. "Novecento sapeva ascoltare. E sapeva leggere. Non i libri, quelli son buoni tutti, sapeva leggere la gente”.(BARICCO, 2002, p.33)

Viajando sempre, com sua alma navegante, o pianista não se contentava com apenas um ângulo de visão. Sabia intuitivamente que eram necessários vários pontos de vista, a fim de capturar, de maneira mais funda, a essência dos seres e das coisas. Isso tudo lhe expandia o espírito, numa viagem sem limites e ele, então, experimentava a liberdade em sua acepção mais plena:

- Devo vedere una cosa laggiù - mi disse.

- Quale cosa?

- Il mare.

- Il mare? 
- Sono trentadue anni che lo vedi, il mare, Novecento.

- Da qui. Io lo voglio vedere da là. non è la stessa cosa.

(BARICCO, 2002, p.45)

Por mais que se pense conhecer algo, por mais sedimentada e estável que seja nossa percepção da realidade, ela jamais será fixa ou imutável.

Assim como o universo movediço do navio, também é a relação que devemos estabelecer com o conhecimento das coisas, dos fatos, das pessoas. Tudo muda. Vivemos em constante mutação. E Novecento sabia disso e precisava de novas perspectivas do olhar, de outras visões do "mesmo mar" (que, embora velho conhecido, ele sabia não ser o mesmo), a fim de traduzi-lo, lendo-o, como aprendera a ler as pessoas, por meio de sua criação. A relativização dos pontos de vista que abre as janelas do pensar, também vem, nesta pesquisa, a confirmar o que se pressupôs anteriormente, a respeito da relativização do conceito de liberdade.

Retomando o fio da meada, tanto em Baricco, como em Buzzati, nas obras específicas que, aqui, analisamos, o que se busca é a dúvida sobre o que o homem contemporâneo entende por ser livre. Adorno vem em nosso auxílio, afirmando que não há liberdade possível, na sociedade capitalista moderna, toda centrada num mundo de aparências. Sustenta, conforme já anunciamos na introdução deste estudo, que estamos vivendo numa verdadeira "prisão a céu aberto" (ADORNO in LETCHE, 2002, p.200)

O personagem Novecento vai sendo desenhado, desde o início de sua aparição como alguém muito "estranho": um indivíduo que passa toda a vida num navio, não existindo oficialmente para o mundo, optando por nele permanecer, até a morte.

Embora, pudesse parecer um despropósito essa sua escolha, o que vale perceber é que, para além da questão limite/ilimitado; prisão/liberdade, Novecento não quis ser um número a mais na multidão.

A nosso ver, sua atitude foi a de resistência à diluição do ser, que aconteceria inevitavelmente, caso ele aderisse à fatal massificação do homem contemporâneo, totalmente perdido, escravo acorrentado aos grilhões de uma sociedade, em que tudo deve servir à reificação sustentada por um discurso utilitário que vai corroendo, inclusive, a concepção da arte. Por meio de sua criação, Novecento transcendeu os limites da proa a 
popa, livre e esteticamente. Tornou-se um nome, adquiriu identidade, vivendo a liberdade em sua essência e não em sua aparência. E o que, a princípio, nos inquietava, aos poucos, se esclarece e comove, como espécie de aprendizado (coerente com as formas lúdicas do seu narrar): a liberdade, em essência, está dentro de nós.

Nas páginas finais do livro, Novecento tenta explicar porque optara por não descer do navio e tudo o que nos revela aponta para a seguinte reflexão: afinal, como é possível ser livre, num mundo tão anônimo e vasto, tão repleto de infinitas possibilidades, múltiplas escolhas, tantos atrativos, tantas ruas, casas, enfim, tantos teclados infindáveis de piano? $\mathrm{O}$ que parece é que ele estremece nossa visão, aguça nossos sentidos, retira-nos da postura de meros leitores/espectadores, jogando-nos no centro do palco, como músicos do grande teatro da vida, em que nossos conceitos e, especialmente, preconceitos precisam ser revistos, repensados:

Tutto quel mondo / Quel mondo addosso che nemmeno sai dove finisce / E quanto ce n'è / Non avete mai paura, voi, di finire in mille pezzi solo a pensarla, quell'enormità, solo a pensarla? A viverla.../

Io sono nato su questa nave, E qui il mondo passava, ma a duemila persone per volta..... Io ho imparato così. La terra, quella è una nave troppogrande per me. è un viaggio troppo lungo. è una donna troppo bella. è un profumo troppo forte. è una musica che non so suonare. Perdonatemi. Ma io non scenderò. (BARICCO, 2002, p. 57)

Gostaríamos de acrescentar, neste momento, o inevitável diálogo entre o que propõe Novecento e o que nos coloca o semi-heterônimo de Fernando Pessoa, Bernardo Soares, no "Livro do desassossego". Ao tratar do que denomina "erudição da sensibilidade", ele define o que considera uma verdadeira experiência, como sendo aquela que:

consiste em restringir o contato com a realidade e aumentar a análise desse contato. Assim, a sensibilidade se alarga e aprofunda, porque em nós está tudo; basta que o procuremos e saibamos procurar (...)

Que é viajar, e para que serve viajar? Qualquer poente é o poente; não é mister ir vê-lo a Constantinopla. A sensação de liberdade que 
nasce das viagens? Posso tê-la saindo de Lisboa até Benfica, e tê-la mais intensamente do que quem vá de Lisboa à China, porque se a libertação não está em mim, não está, para mim, em parte alguma(...) Condillac começa o seu livro célebre: "Por mais que subamos e mais baixo desçamos, nunca saímos das nossas sensações." Nunca desembarcamos de nós. Nunca chegamos a outrem, senão outrando-nos pela imaginação sensível de nós mesmos(...) Quem cruzou todos os mares cruzou só a monotonia de si mesmo(...) Nos países que os outros visitam, visitam-nos anônimos e peregrinos. Nos países que tenho visitado, tenho sido, não só o prazer escondido do viajante incógnito, mas, a majestade do rei que ali reina, e o povo cujo uso ali habita, e a história inteira daquela nação e das outras. As mesmas paisagens, as mesmas casas eu as vi porque as fui, feitas em Deus com a substância da minha imaginação.(PESSOA, 1999, p.155-6, grifo nosso)

Importa perceber, também, o quanto Baricco propõe, de modo reiterativo (conforme verificaremos na análise subseqüente das demais obras, nos próximos capítulos) a séria discussão que poderia, talvez, se resumir em torno da idéia central do que vem a ser a zona limítrofe da tênue linha de fronteira entre o ser e o mundo.

Num primeiro momento, numa leitura superficial da decisão de Novecento, poderíamos concordar com Ryszard Kapuscinski, jornalista polonês, que dizia ser fundamental "cruzar a fronteira". De fato, este jornalista teria passado a vida viajando, buscando o diverso, pois acreditava que, só a partir do conhecimento do que está do outro lado, além da fronteira limitadora, poderia conhecer o outro e apenas por meio da alteridade se chegaria à própria identidade.(KAPUSCINSKI apud CARVALHO, 2007)

A asseverar essa tese, Novecento precisaria necessariamente sair do navio, para "cruzar a fronteira" e, numa experiência quase que inaugural, passar a existir (pois "enclausurado", não teria como conhecer o mundo, não teria como "outrar-se" e, portanto, não teria como "ser"). Porém, o que queremos é propor um outro modo de ler a atitude de Novecento. Ele "cruzou a fronteira", sem ter precisado, materialmente, sair dela. A propósito, Novecento exemplifica, de certo modo, a postura do escritor francês Victor Segalen que:

não cruza a fronteira para conhecer o outro e reduzi-lo a objeto do seu saber, mas para, tomando consciência do mistério de uma 
alteridade intransponível, afirmar a radicalidade da sua própria individualidade, que não é outra coisa senão a capacidade de ver e cultivar a diferença em si mesmo - também como autor e artista. (SEGALEN apud CARVALHO, 2007)

Sabemos o quanto Novecento "viajava". Viajava por meio de sua arte, de sua imaginação. Assim como Soares, experimentando a liberdade em si, "encantou" aquele universo do navio, possível metáfora do mundo: "I desideri stavano strappandomi l'anima. Allora li ho incantati..." (“Os desejos estavam arrancando-me a alma. Então os encantei...”) (BARICCO, 2002, p.58)

Tanto Novecento, quanto o peixe vermelho, cada qual a seu modo, sabiam dos perigos da traiçoeira armadilha do viver. Talvez, uma das saídas, seja a de perscrutar, por que, embora tenhamos nascidos livres, continuamos a nos submeter à alienação da sociedade que escraviza.

Partindo da relativização do conceito de liberdade, em Novecento, pretendemos perceber, conforme demonstraremos nos próximos capítulos desta pesquisa, que há uma correspondência entre a multiplicidade de vozes narrativas que se apresentarão, principalmente, em Castelli di rabbia e a pluralidade de pontos de vista, sobretudo em Oceano mar.

O universo acaba sendo posto em dúvida, por meio desse jogo, em que nada parece permanecer no mesmo lugar. Talvez, essa tendência a não concentrar uma verdade absoluta na voz de um único narrador, aliada à convicção de que não há um, mas infinitos modos de ver a realidade traduzam um pouco da experiência de que ser livre implica algo mais essencial e menos aparente. Ou, de modo mais simples: a verdadeira liberdade se relaciona intrinsecamente às múltiplas possibilidades de narrar, o que, por sua vez está diretamente vinculado à relativização dos diferentes pontos de vista, das infinitas janelas que o olhar pode descortinar.

Talvez, quanto mais livres formos, narrando a vida e alargando nossa percepção da realidade, possamos tocar a liberdade, em essência.

O pianista se liberta, por meio da vivência sensível de sua arte. O peixe se liberta pela consciência da sensação de liberdade, em oposição à consciência do cárcere da eterna insatisfação. 
A nós, nesta lúdica travessia, que nos oferecem os textos de Baricco e Buzzati, cabe apenas reavivar o ponto de interrogação da alma que, às vezes, de tão escondido, parece não fazer mais parte da pontuação de nossa história... 


\section{$3^{\circ}$ Capítulo:}

\section{Castelli di rabbia:a narrativa como resistência}

\subsection{Castelli di rabbia: $O$ resgate do homem emudecido}

Como fazer falar o que foi obrigado a emudecer? Como buscar um sentido, em meio às ruínas dos circos de horrores do pós-guerra, do embrutecimento que acabou mutilando a expressão? Que tipo de vazio é esse que se instaura no que, às vezes, de tão verborrágico, denuncia, precisamente, essa aridez, essa falta da capacidade primeira da troca de experiências?

Alessandro Baricco parece ter plena consciência da crise desencadeada pela retórica aprisionante do silêncio. E não se conforma com ela. Ao contrário, parece buscar, quase como um discípulo benjaminiano, a força e o vigor das narrativas ancestrais, capazes de resgatar traços de nossa humanidade calada, de nossa sensibilidade anestesiada. Importa perceber que essa tentativa de recuperar o contador de histórias, ao redor do calor do fogo, que aquece os frios de nossa existência, não se reflete, em Baricco, como uma postura nostálgica ou apocalíptica, de simples lamento e total desesperança, em relação ao que se perdeu. O que, de fato, surpreende é a sua capacidade de atualizar, ficcionalmente, em termos contemporâneos, a antiga lição do grande filósofo.

Diante da desintegração da identidade da experiência, já que não há mais tempo, nem espaço para histórias que sejam contadas, nem pessoas que queiram ouvi-las, é urgente reinventar o narrador. Daí, porque em seu primeiro romance, Castelli di Rabbia, no amplo leque de vozes narrativas que se abrem, há a seguinte constatação:

La verità è che si vedono e si sentono e si toccano così tante cose... è come se ci portassimo dentro un vecchio narratore che per tutto il tempo continua a raccontarci una storia mai finita e ricca di mille particolari. Lui racconta, non smette mai, e quella è la vita....... Ci sono certi che lo chiamano angelo, il narratore che si portano dentro e che gli racconta la vita. (BARICCO, 1999, p.116)

Narrar, portanto é, mais que tudo, um ato de resistência. Narrar é restituir a vida que, de uma ou outra forma, nos vai sendo, quotidianamente, negada. E, enquanto estivermos atentos ao que nosso velho narrador, aquele que habita em cada um, nos conta, 
então, estaremos salvos e tal como Sherazade, nos livraremos da morte. Já que narrar é viver, temos implícita à essa noção, que tratar desse universo significa, necessariamente, mergulhar num corpus mutante, instável e movediço, em plena transformação. Narrar é, pois, assumir-se em constante metamorfose.

A propósito, em interessante discurso, proferido em Munique, intitulado $O$ ofício do poeta, Elias Canetti observa a importância do poeta, como aquele a quem denomina: “guardião das metamorfoses". E nos esclarece:

Num mundo onde importam a especialização e a produtividade; que nada vê senão ápices, almejados pelos homens em uma espécie de limitação linear; que emprega todas as suas energias na solidão gélida desses ápices, desprezando e embaciando tudo o que está no plano mais próximo — o múltiplo, o autêntico —, que não se presta a servir ao ápice; num mundo que proíbe mais e mais a metamorfose, porque esta atua em sentido contrário à meta suprema de produção; que multiplica irrefletidamente os meios para sua própria destruição, ao mesmo tempo em que procura sufocar o que ainda poderia haver de qualidades anteriormente adquiridas pelo homem que poderiam agir em sentido contrário ao seu - num mundo, que se poderia caracterizar como o mais cego de todos os mundos, parece de fundamental importância a existência de alguns que, apesar dele, continuem a exercitar o dom da metamorfose. (1976)

Baricco exercita bem esse dom. Para ele, o ato de narrar é, acima de tudo, matéria de salvação. Coincidente é o que nos revela Ivone Bordelois, pois: “A linguagem está antes e depois de nós, mas também está, felizmente, entre nós. É tecido relacional do qual dependem os outros: um tecido forte e subsistente e tão necessário a nossas vidas como a nutrição" (2005, p.30)

Essa crença na força de narrar e na busca de certo frescor original das narrativas orais mais simples e despojadas, também, pode ser verificada na produção teóricoensaística de Baricco. Ele nutre, de fato, profunda admiração por Joseph Conrad, famoso autor polonês que, obrigado a deixar a terra natal, acaba por se radicar na Inglaterra, tornando-se um dos maiores escritores de Língua Inglesa. Seu livro Coração das Trevas (que deu origem ao filme Apocalipse Now, de Coppola), em italiano Cuore di Tenebra, conta com o posfácio: "Andata e ritorno, destinazione l'orrore.", escrito por Baricco. $\mathrm{O}$ 
que mais nos chama a atenção é o quanto o autor elogia o fortíssimo traço de oralidade que impregna a narrativa conradiana. Baricco encontra em Conrad, aquilo que já postulava Benjamin sobre a simplicidade e o não adensamento psicológico das histórias contadas espontaneamente (que, justamente por isso, são as que mais permanecem na memória):

Não há nada que de forma mais duradoura recomende histórias à memória do que aquela casta concisão que as subtrai à análise psicológica. E quanto mais natural o modo pelo qual se dá, para o narrador, a renúncia ao matizamento psicológico, tanto maior se torna sua candidatura a um lugar na memória do ouvinte, tão mais plenamente as histórias se conformam à experiência pessoal dele, tanto maior é sua satisfação em, mais dia menos dia, voltar afinal a contá-las. (BENJAMIN, 1980, p.62)

De fato, o confuso narrador Marlow de Coração das Trevas parece exemplificar um modo, por assim dizer, "imperfeito" de narrar. Para Baricco, essa é uma feliz constatação, já que ele defende a tese de que a força do grande Conrad reside exatamente nisso: no jogo com que manipula a linguagem, consciente de que seu fazer literário precisa buscar o que apenas "aparenta" ser mal acabado. O resultado de tal procedimento é a recuperação da vitalidade espontânea das narrativas que tocam de perto a instância oral:

Prendere atto di simili imperfezioni non è un modo di svalutare l'opera di Conrad: è un modo di collocarla nell'universo che è suo. Conrad non scriveva, semplicemente, male. Quel che Conrad scriveva dimora un passo prima della letteratura: e un passo appena oltre al semplice, rudimentale, primitivo narrare. Le sue sono opere di confine. La loro imperfezione si tramuta in forza se si riconosce in essa il crepitare di un rito originario e mille volte più carismatico della letteratura: "la narrazione". Prima di essere opere scritte, i suoi libri sono registrazioni di una narrazione orale: recano su di sè ruvidezze e gli squilibri di una forma di racconto primitiva, originaria. (BARICCO, 2003, p.120)

O que fica, portanto, muito evidente é que há uma profunda coerência no que Alessandro Baricco postula como teórico e no que procura realizar em sua ficção.

No que toca à central questão da oralidade, não faltariam exemplos, colhidos em sua obra, que pudessem ilustrá-la. A propósito, há um trecho bastante extenso em que a viúva 
Abegg narra a história de seu encontro com o senhor Pekish, no romance Castelli di Rabbia. Tem-se a impressão de que se trata de uma fala integralmente transcrita de um gravador. Ou seja, é como se esta personagem (que no momento assume a voz narrativa) estivesse nos contando sua história, ao vivo. A fim de explicitar os ruídos, interferências e interrupções que caracterizam essa forma "imperfeita" e espontânea de narrar, o autor escreve três longas páginas, sem usar, sequer, um parágrafo. As frases vão se dispondo em fragmentos, seguidos, o tempo todo, apenas de reticências, como se fossem blocos dispersos, flashes de idéias lançadas no espaço branco da página, tal como se registram, numa fita virgem, as múltiplas dissonâncias e entonações da voz. As palavras são escritas como se quisessem capturar o fluxo descontínuo, redundante, confuso e verborrágico do falar, em que a pontuação, a pausa, a coerência e a coesão das idéias importam menos do que a liberdade, o desregramento, a soltura e espontaneidade da narrativa genuinamente oral. Parece "convocar" o interlocutor, o entrevistador, enfim, o leitor, já que a todo momento, se enuncia um: “capisce?”(“entende?”) ou "sa?”(“sabe?”), sinalizando, por meio deste recurso fático, que, embora totalmente à vontade, em seu discurso escorreito e desenfreado, o narrador não se perdeu em suas divagações e quer se asseverar de que estamos todos ali presentes, todo- ouvidos, atentos à sua história:

Però non lo vidi subito, sa?... c'era un acquazzone fortissimo e poi era notte, non lo vidi subito. Poi però lo vidi. Ed era incredibile ma lui stava là sotto quel diluvio, capisce? inginocchiato nel fango, capisce? stringendosi la testa fra le mani, così... lo so che è strano, ma...era così... e io lo vidi e non ebbi più paura... anzi, per così dire... mi infilai il mantello addosso, sa?... e corsi sotto la pioggia gridando "Signor Pekish, signor Pekish", e lui niente, sempre là, come una statua... era anche un po' ridicola tutta quella scena, capisce?... lui là inginocchiato e io a saltellare nel fango sotto quel diluvio... non so... alla fine lo presi per le mani e lui si alzò, lentamente, e lo riportai a casa... lui si faceva portare, capisce?...non disse nulla...(BARICCO, 1999, p.89)

De modo análogo, a quarta parte do romance se abre com a presença de uma outra voz, totalmente diversa da dos demais narradores já apresentados. Ela começa interpelando: 
"... come sarebbe a dire "per caso"?... tu credi davvero che ci sia qualcosa che succede "per caso"? io dovrei credere che questa mia gamba stritolata è un caso? o la mia fattoria, e la vista che c'era, e quel sentiero... o quello che sento la notte, invece di dormire, tutta la notte... è giù da quel sentiero che se n'è andata, Mary... non ne poteva più, e un giorno se n'è andata via... ha preso quel sentiero e se n'è andata...(BARICCO, 1999, p.161)

Tal como na história contada pela viúva Abegg, este narrador, a princípio, anônimo, começa a contar, de modo totalmente fragmentado, a sua história (mais uma vez, outra história que se abre, no leque infinito das mil e uma histórias de Quinnipak). O modo como ele conta é quase que a reprodução de um discurso tipicamente oral. Colaboram para tanto, a pontuação irregular, repleta de reticências que visam representar a fragmentação deste discurso confuso, verborrágico, em que as idéias não são concatenadas pela lógica do raciocínio, mas pelo atropelo da fala reticente. Tudo se concentra num só parágrafo, que pretende condensar essa narrativa desenfreada, confessional, que, às vezes, não conta, nem mesmo, com a sinalização de letras maiúsculas para abrir uma outra frase. Tudo remete às categorias da oralização, em que os elementos fáticos prevalecem em detrimento da organização de uma sintaxe elaborada.

Aos poucos, a fala confusa, que busca traduzir a desordem do pensamento desse narrador, vai conduzindo à tese por ele pretensamente defendida de que nada, na vida, acontece por acaso, ou seja, tudo, diz ele, é traçado pelo destino.

Assim, vamo-nos aproximando desta história: a de um homem, chamado Kuppert, que também tocava na banda de Pekisch, que trabalhava para os Rail e que acabará sendo preso por assassinar sua esposa Mary.

Porém, nada desse enredo nos vem gratuito e simplificado. Ao resumir o seu contar, tudo se reduz a essas poucas linhas que acabamos de descrever. Mas, é exatamente por dar voz a Kuppert, por permitir que ele conte a própria história, que o autor ilumina a narrativa, colorindo-a da cor do humano, por meio desse recurso que é o de aproximar, ao máximo, o ouvido daqueles que têm algo a dizer, seja qual for a maneira que encontrem para verbalizar o que sentem, pensem, almejem.

Então, depois de muitas interrupções e divagações do tipo: "Tinha que acontecer e aconteceu e... pronto..." fica-se sabendo que ele perdera uma perna num acidente, o que o 
transtornara muito. Segundo o que narra, nunca mais, depois do acidente, ele fora o mesmo e admite que, para Mary, sua mulher, "que era bonita, mas não linda, tudo chegara ao limite do insuportável. Ele teria se transformado em alguém difícil, e isso, de certa forma, justificaria o fato dela tê-lo abandonado. Mas o curioso é que, em vez de ir direto ao ponto culminante, a razão de ter cometido o crime, ele começa a tergiversar sobre um fato, aparentemente alheio ao episódio em si: o fato de que, por obra do destino, ele teria ido à feira de Trinniter, apenas e somente para comprar uma tesoura de podar.

A narrativa, então, se demora, exatamente como quando uma pessoa está contando algo e uma série de outros elementos interferem, como recursos fáticos que visam manter a atenção do ouvinte, aumentar-lhe a curiosidade sobre o desfecho, etc...

Enquanto leitores, caímos na rede desse hábil narrador, ansiosos para que ele chegue logo ao fim. Mas, na grande viagem a Quinnipak, o que importa é perdurar e não chegar.

Assim, aos poucos, ele nos revela que o problema só se dera porque o destino quis que ele fosse a Trinniter, a uma feira, para comprar uma tesoura de podar (ele que, também, gostaria de comprar um baú para guardar bugigangas), quando de repente, acabara vendo Mary. Interessantíssimo este momento em que ele começa a levantar uma série de hipóteses sobre como teria sido, se em vez da tesoura, ele segurasse, por exemplo, flores nas mãos.

A retórica aqui pretende atenuar a brutalidade do crime (imaginemos como esta história seria contada por outro, por alguém que tivesse presenciado a cena, ou como a própria vítima teria narrado a situação, se pudesse falar). No fundo, o discurso de Kuppert busca sensibilizar o júri (no caso, o leitor/ ouvinte/espectador), a fim de tentar provar que tudo fora obra do destino, pois foram os seus trilhos (os do trem do seu destino) que:

mi portarono fino a un passo da Mary, in mezzo alla gente, fece appena in tempo a vedermi poi la roncola la sventrò, come un animale... un mare di sangue... e le urla, quelle mi suonano ancora in testa adesso, urla così non le avevo mai sentite.... ma anche quelle.... anche quelle non avevano fatto altro per anni che aspettare me... un grido è capace di aspettarti per anni, poi tu arrivi un giorno, e lui è lí, puntuale, terrificante... tutto....tutto è così.... tutto quello che incontri è già lì da sempre, ad aspettarti.... anche tu, cosa credi? e questa schifosa prigione.... tutti fermi ai bordi dei binari, aspettando che io passi... 
Passerò.... passerò.... Dite alla forca che mi aspetta che passerò anche da lì. Una notte ancora e avrà finito di aspettare.(BARICCO, 1999, p.166)

Baricco serve-se deste tipo de procedimento para exacerbar, ao máximo, quase a nível da caricatura, a fonte primeira de todas as histórias, as que se transmitem, naturalmente, de um contador de casos a outro, fazendo vir à tona, algo tão peculiar à nossa humanidade: 0 ato espontâneo de contar.

Se hoje a violência contra a palavra leva ao mutismo que embrutece e isola o ser humano em ilhas de alienação e ensimesmamento, é, então, necessário recuar ao tempo do "Era uma vez" e fazer com que aquela infinita variedade de vozes narrativas germinem.

Para resgatar a palavra, instrumento essencial, neste processo de reumanização, ele exagera na multiplicidade dos narradores, diluindo assim, o poder e a força que apenas um único narrador onipresente e onisciente poderia concentrar. Por meio de um fruir desonerado e gratuito, o homem precisa voltar a se deleitar, ainda, com histórias que se contam, recuperando o prazer de ouvir-ler. Pois essa delicada "matéria-prima fina vida" (VELOSO, 1979) depende do infinito círculo de troca, potencializado no singelo e gratuito ato de contar. Daí, porque a arte de narrar em Baricco tem como premissa a "artesania" dos múltiplos e coloridos fios de um bordado, em que importa menos o desenho final da composição e mais o vaivém da agulha, num jogo sinuoso, espontâneo e descompromissado.

Castelli di rabbia, romance de estréia de Baricco (1991), nos apresenta, logo ao início, um reino mágico, um lugar chamado Quinnipak, onde uma série de personagens de nomes estranhos viverá à procura de seus mais mirabolantes sonhos.

Assim, temos a grande mansão dos Rail, em que vivem o sr. Dann Rail e sua belíssima esposa Jun, cercada de milhares de empregados. Ele é o dono de uma importante fábrica de vidro, mas seu grande sonho é o de construir uma ferrovia, para poder fazer andar, nos trilhos, um trem, cujo nome será Elisabeth. Há, também, o músico sr. Pekisch que tem um auxiliar, o menino Pehnt (que, na verdade, é um órfão, que Pekisch e a viúva Abegg criam). O sonho de Pekisch está em descobrir um tubo que preserve a integridade dos sons, ainda que à longa distância (na verdade, as pesquisas incipientes, em torno da origem do telefone). Mas, o mais interessante é a sua busca pela nota que o constitui, pois 
ele acredita que cada ser humano tem uma nota que lhe é própria e única, totalmente diferente das demais. Devido a essa crença, dedica-se às suas pesquisas, no universo da música e dos sons e chega a criar o Humanófono, espécie de órgão formado por teclas humanas (cada pessoa, quando tocada, emite o seu som, particular, único e inconfundível).

Temos, também, a curiosa figura da viúva Abegg, cujo noivo só conhecera por cartas, já que acabará morrendo antes de desposá-la (mas, mesmo assim, ela se considerará sua viúva).

Há o fascinante sr. Hector Horeau, genial e brilhante arquiteto, cujo sonho é o de construir um gigantesco palácio de vidro (como, de fato, conseguirá), a fim de que as pessoas possam ver tudo ao redor, protegidas pelo vidro, mas, ao mesmo tempo, integradas ao mundo exterior.

E a grande revelação, concentrada em Jun que, a princípio, surge como a bela esposa do sr. Rail, para afinal nos surpreender como aquela que detém o poder de narrar todas aquelas histórias, frutos de sua imaginação criativa.

Todos esses personagens vivem em busca da realização de seus projetos, construindo seus castelos particulares que, inevitavelmente (conforme veremos adiante), acabarão ruindo.

Interessante notar o quanto é difícil recompor um único eixo ficcional, na narrativa de Baricco. O que temos, tanto em $\mathrm{CR}$, como em OM, é um conjunto de histórias que vão se abrindo em outras, num processo ininterrupto, em que, muito mais do que manter a coerência da história tradicional em alguns romances, com início, meio e fim, o objetivo, aparentemente, é o de fazer com que as múltiplas histórias convivam como células independentes a capturar o leitor que, justamente porque entretido em cada uma delas, pode perder o fio da meada, perdendo-se do início, de onde tudo começou e ficando totalmente entregue ao momento do que se está contando ali, naquele preciso instante. Não há, portanto, apenas uma história principal; há várias histórias que se cruzam e se tocam, convivendo com o que parece ser o eixo primeiro da narrativa. Isso tudo visa reforçar a idéia das narrativas orais, da crença de que há infinitos narradores (que diluem a onipresença centralizadora de um único, tirânico narrador), distintos modos de narrar, e o como se conta vale mais do que $o$ quê, propriamente, se conta. Daí porque parece ser difícil "recontar", afinal, o plot que dá origem a CR, tal como a OM. 
O início do romance Castelli di rabbia apresenta uma curiosa construção. Os empregados da mansão dos Rail são todos envolvidos com a chegada de um "pacote para a senhora Rail'. Este primeiro capítulo se constrói, em torno desta simples notícia. Mas o que nos chama a atenção é que, ao fazer com que um passe a mensagem a outro e assim sucessivamente, (Arold conta a Brath que, por sua vez conta a Pit, que conta a Angy que conta a Magg) o que deveria chegar à destinatária, $\mathrm{Sr}^{\mathrm{a}}$ Rail, de modo objetivo, rápido e claro, vai se modificando, sofrendo uma série de intervenções, esquecimentos, acréscimos, rupturas, desgastes, que denunciam o inevitável ruído da mensagem. Então, numa espécie de brincadeira de "telefone sem fio", a mensagem repetida, distorcida, vai ecoando num crescendo, a fim de aguçar toda curiosidade do leitor que, por conta dessa excessiva prorrogação do revelar o significado do tal "pacote", anseia por "desembrulhá-lo", retirando os invólucros todos, afastando os mensageiros todos, para atingir o sumo daquele fruto proibido, justamente porque muito bem guardado. Interessantíssimo o jogo que aqui se propõe. A partir do que o senhor Brath diz a Pit: "è un pacco per la signora Rail; è arrivato ieri sera e... e vieni da lontano", ("é um pacote para a senhora Rail; chegou ontem à noite e... e vem de longe") ao final Pit, quando conta a Magg, transforma a mensagem original em: "è un pacco per la signora Rail; è arrivato ieri e... è arrivato ieri...; è arrivato ieri e ha l'aria lontana, ecco".("é um pacote para a senhora Rail; chegou ontem e... chegou ontem... ; chegou ontem e tem um ar longínquo, é isso") (BARICCO, 1999, p.16 -17, grifo nosso).

Apresenta-se então, do ponto de vista de sua corporeidade, um pacote, que deve conter algo e, por meio da elaboração de sua história que passa de narrador a narrador, cresce e se modifica, acaba adquirindo alma, ele se adjetiva poeticamente, se humaniza, passando de simples "pacote para a $\mathrm{Sr}^{\mathrm{a}}$ Rail, que chegou ontem e vem de longe" a um "pacote para a $\mathrm{Sr}^{\mathrm{a}}$ Rail, que chegou ontem e tem um ar longínquo, distante", uma expressão, um aspecto, uma aparência, tal como uma pessoa que tem um ar distraído ou um ar cansado, um ar estranho, alegre, triste, etc... E esse eco longínquo de um pacote que vem de longe, também traz um significado que vai se revelando aos poucos, e os diversos empregados mensageiros, que foram incumbidos de fazer chegar a notícia à $\mathrm{Sr}^{\mathrm{a}}$ Rail passam a repeti-la, agora, não mais de modo fragmentário e ruidoso, passam quase a cantar em 
coro, em uníssono, numa espécie de gran finale, o que se anunciava, implícito à chegada do pacote: "Sta per tornare il signor Rail". ("O senhor Rail está para chegar".)

Este tipo de procedimento, que se configura no miúdo, na microestrutura textual, aponta para o grande corpus da narrativa de Baricco. Esse jogo de um signo que remete a outro, que, por sua vez, remete a outro, e assim por diante, revela a ininterrupta tessitura de histórias que se abrem ad infintum, pois, em última instância, não morreremos, enquanto soubermos contar e ouvir histórias.

O mesmo intuito de fazer perdurar a narrativa, aguçando a curiosidade do leitor, sobre o que há dentro do pacote, ocorre quando a senhora Jun Rail passa a abri-lo:

Jun Rail si alzò, prese il pacco, lesse il suo nome scritto in inchiostro nero sulla carta marrone, rigirò il pacco, alzò lo sguardo, chiuse per un istante gli occhi, li riaprì, tornò a guardare il pacco, prese il tagliacarte sullo scrittoio, tagliò lo spago che lo teneva insieme, aprì la carta marrone e sotto c'era una carta bianca (...) Aprì la carta bianca, che avviluppava una carta rosa, che impacchettava una scatola viola dove Jun Rail trovò una piccola scatola di panno verde. La aprì. Guardò. Non si mosse nulla nel suo viso. La richiuse. Allora si voltò verso Magg, le sorrise e disse: - Sta per tornare il signor Rail.(BARICCO, 1999, p.19)

O minucioso gestual de Jun Rail, diante de uma tarefa tão simples, como a de abrir um pacote, adquire conotação ritualística. E nessa demora, nesse saber fazer perdurar a história, criando todo o suspense, o narrador vai prendendo, capturando o leitor na urdidura hábil de sua trama. O vaivém de sua agulha ágil não se perde. Ao contrário, estabelece um ritmo nesse bailado de movimentos precisos, que, com um passo adiante, outro atrás, vai compondo a estética lúdica do saber narrar.

Temos "um papel branco, que envolve um papel rosa, que embrulhava uma caixa roxa, onde ela encontrou uma pequena caixa de pano verde". Inevitável, não comparar esta cena à do mágico que, de dentro de sua cartola ou caixa de surpresas tira, um após outro, diversos lenços coloridos, numa profusão esfuziante de cores, até finalmente revelar um grande segredo. 
No início da segunda parte, enquanto o narrador em terceira pessoa, conta o reencontro amoroso do sr. e da sr $^{\mathrm{a}}$ Rail, há, propositalmente, a inserção de uma outra história dentro do eixo narrativo principal. É a história do trem, que fazia o trajeto Londres-Dublim. Cumpre observar que, temos aqui uma voz narrativa linear, seqüencial, que, de repente, tal como ocorre nas narrativas orais, revela uma espécie de lembrar que se superpõe a outro, gerando um caos, uma desordem no ato de contar (percebemos que esse procedimento ocorre com frequiência, em diversos momentos). Então, abre-se, com dois pontos, aspas e em itálico, a tal história do trem, que lembra uma história ancestral, colhida, sabe-se lá em que arquivo da memória das histórias fantásticas, sobre as primeiras locomotivas:

"Tutte le mattine, un messo dell'Ammiragliato consegnava all'impiegato di turno del treno postale Londra-Dublino un orologio che indicava l'ora esatta. A Holyhead l'orologio veniva consegnato agli impiegati del traghetto di Kingston che lo portava a Dublino. Al ritorno gli impiegati del traghetto di Kingston riportavano l'orologio all'impiegato di turno del treno postale. Quando il treno arrivava di nuovo a Londra l'orologio veniva riconsegnato al messo dell'Ammiraglio. Così, ogni giorno, per centinaia di giorni."

Erano i tempi in cui nella stazione di Buffalo c'erano tre orologi, ognuno con un'ora diversa, e sei ce n'erano nella stazione di Pittsburgh, uno per ogni linea ferroviaria che passava - era la Babele delle ore - e allora si capisce il rito della Londra-Dublino, treno postale - quell'orologio che va avanti e indietro, in una scatola di veluto, passando di mano in mano, prezioso come un segreto, prezioso come un gioiello.(BARICCO, 1999, p.58)

Mais uma vez, coerente à sinuosidade dos fios que vão e vêm das histórias que se desdobram em outras, o relógio adquire outro significado, para além de mero marcador do tempo, na confusão da Babel das horas. É um relógio que passa de mão em mão, um relógio que vai "para frente e para trás", em uma caixa de veludo, como um segredo, uma preciosa jóia. Tudo, então, se concentra nos rituais de passagem. O tempo cronológico se suspende, em função da maravilha daquilo que vai perdurando, para além das horas, na troca de experiências, no tempo eternizado das histórias. Daí o porquê desse tom de ancestralidade, de um tempo que se quer fazer parar, a fim de fazer ressoar aquelas vozes das histórias populares, velhas conhecidas, narradas por diversos e sábios narradores. 
Estas narrativas nos atraem, justamente porque, mesmo girando em torno de uma mesma, única história, serão capazes de adquirir infinitas nuances, cores, tonalidades diversas, graças à relativização dos pontos de vista de quem as conta. Percebemos nessas sinalizações: "Era uma vez", "Todas as manhãs", "Eram os tempos em que...", "E assim por centenas de dias", etc, a recuperação do reino mágico dos contos de fada, em que o tempo se suspende, reino que não envelhece jamais, eternizado nos porões inconscientes da infância e capaz de nos remeter à memória de nossa humanidade essencial e genuína.

Interessante notar que não se pretende configurar aqui, nem o tempo cronológico, nem o psicológico, pois estamos tocando a tênue, delicada e fugidia fronteira do tempo mítico, em que importa permanecer e se deixar levar, enternecer pelo colo das histórias que nos embalam. Este artifício do narrar, de certa forma, reitera a crença na idéia de que importa permanecer na viagem, já que tudo está concentrado ali, na força germinativa daquilo que se conta, mais ainda, no modo como se conta. Então, é proposital fazer com que o leitor se perca e se deixe levar pelo contar. E parece inevitável não apontar como um forte traço da narrativa de Baricco essa maestria em saber conduzir o leitor, por esse reino em que tudo se suspende, inclusive certa percepção de continuidade, de linearidade, de começo, meio e fim. Interessante, porque em diversos momentos, o leitor, se tivesse que recuperar o quê se conta, provavelmente não saberia, tal é seu envolvimento com o narrador daquele instante, daquela história, dentro da história principal (que, de tão diluída pelo colorido dos demais fios que tecem o bordado, deixa de representar a função tradicional do romance em que todos os elementos se amarram, em torno do enunciado principal)

Logo em seguida, novamente, outra história se sobrepõe a essa do trem, e agora ela se introduz por parênteses, pois é uma história que já foi contada antes: aquela de um homem que partia, viajava, e quando estava para voltar, fazia com que chegasse à sua amada, como prenúncio de sua volta, uma jóia, em uma caixa de veludo. Trata-se da história do sr.e da sr ${ }^{\mathrm{a}}$ Rail:

(C'era un uomo che partiva, viaggiava, e quando tornava, prima di lui arrivava un gioiello, in una scatola di velluto. La donna che lo aspettava apriva la scattola, vedeva il gioiello e allora sapeva che sarebbe tornato. La gente credeva che fosse un regalo, un prezioso regalo per ogni fuga. Ma il segreto era che il gioiello era sempre lo stesso. Cambiavano le scatole ma lui era sempre quello. Partiva 
con l'uomo, restava con lui ovunque andasse, passava di valigia in valigia, di città in città, e poi tornava indietro. Veniva dalle mani della donna e lì ritornava, esattamente come l'orologio ritornava nelle mani dell'Ammiraglio. La gente credeva fosse un regalo, un prezioso regalo per ogni fuga. Invece era ciò che custodiva il filo del loro amore, nel labirinto di mondi in cui l'uomo correva, come un'incrinatura lungo un vaso. Era l'orologio che contava i minuti del tempo anomalo, e unico, che era il tempo del loro volersi. Tornava indietro prima di lui perchè lei sapesse che dentro colui che stava arrivando no si era spezzato il filo di quel tempo. Così, l'uomo arrivava, infine, e non c'era bisogno di dir nulla, di chiedere nulla, né di sapere. L'istante in cui si vedevano era, per tutt'e due, ancora una volta, lo stesso istante.) (BARICCO, 1999, p.58)

A análise desse trecho permite-nos estabelecer uma série de reflexões sobre a arte de narrar em Baricco. Tal como o relógio que passava de mão em mão, entre os almirantes da ferrovia que ligava Londres a Dublim, aqui também a jóia que, embora envolvida pelas mais diversas caixas e por múltiplos papéis coloridos, conforme se constatou, permanece sendo sempre a mesma. Esta jóia, este segredo que viaja mundos distantes, perambulando de mão em mão, antes de chegar ao destinatário, num vaivém rítmico e ritualístico, parece querer representar a riqueza do que se guarda para ser trocado como experiência, ou seja, a semente da narração como pérola da metamorfose humana. Assim:

Andavano e venivano, i treni, come matti. E tutta la gente, a scendere e a salire, ognuno a cucire la sua storia, con l'ago della propria vita, lavoro maledetto e bello, compito infinito.(BARICCO, 1999, p.193)

No recôndito da concha, no segredo do pacote, dentro das incontáveis caixas, nos vagões de inumeráveis trens, na suspensão das horas, guardam-se, amorosamente, as histórias, embriões demasiado humanos, fios de Ariadne, que podem orientar a saída do labirinto dos condicionamentos e da alienação, rumo à liberdade.

Outra questão que não pode ser desprezada, na análise deste romance, é a escolha muito pontual, como epígrafe a percorrer todo o livro, da última estrofe da Décima Elegia da obra Elegias de Duíno de Rainer Maria Rilke (2001), com quem Baricco estabelece um importante diálogo. 
De fato, Castelli di rabbia, dividido em sete partes, apresenta os versos desta elegia seqüencialmente, como uma espécie de light motiv, de abertura, a ouverture da peça que se pretende executar. Vejamos:

Und wir, die an steigendes Glück... (epígrafe da primeira parte) ...denken, empfänden die Rührung... (epígrafe da terceira parte) ...die uns beinah bestürzt, ... ...wenn ein Glückliches fällt. (epígrafe da quinta parte) (epígrafe da sétima parte) (RILKE, 2001 apud

BARICCO, 1999)

E nós que imaginamos a ventura em ascensão, sentiríamos uma ternura imensa, quase perturbadora, quando uma coisa feliz cai... (RILKE, 2001, p.97)

O que conseguimos notar, na leitura atenta destas partes, é que na primeira e na terceira, respectivamente, parece haver a construção, a elevação dos castelos de cada um dos personagens.

Por exemplo, é o momento da apresentação do sonho do sr. Rail: o do projeto da locomotiva Elisabeth; o das tentativas de criação de um tubo que pudesse conduzir os sons de Pekisch e a incansável busca pela sua nota musical (já que ele acreditava que cada ser humano tem a sua própria nota, que, cedo ou tarde, acabaria se revelando); o projeto de construção de um edifício-palácio-castelo de vidro, de cristal transparente do sr. Hector Horeau, o Crystal Palace.

Cada qual, nestes capítulos iniciais, parece seguir a curva ascensional, a do sonho que se quer realidade, a de ideais que trazem em si, toda potencialidade do que, em latência, se almeja, a de algo positivo, no sentido do querer e se mobilizar para a concretização. Então, há uma construção estrutural de "crescendo", neste momento. Mas o que mais chama a atenção é que após a terceira parte, sobretudo na sexta e sétima, todos os castelos, antes erguidos, começarão a ruir. Nada permanecerá no lugar: haverá a destruição da ferrovia; o castelo de cristal estilhaçado em mil pedaços, depois do incêndio; Pekisch, o sonhador de sons, morrerá, devido aos delírios provocados por uma febre musical (muito semelhante à 
que acometeu o poeta alemão Hölderlin, na torre de Tübingen (HÖLDERLIN, 1994)); o sr. Horeau acabará louco e Jun Rail partirá.

Enfim, tudo irá aos ares ou desmoronará. Quem sonhou terá que despertar... E fica, então, evidente que estas últimas partes se articulam num movimento decrescente, em que a descrição das respectivas quedas é que confere a tônica do narrar. Muito coerente aos versos citados de Rilke, já que, logo de início, somos levados a uma "ventura em ascensão" para em seguida, "sentir uma ternura imensa, quase perturbadora" (o leitor pactua da fabricação dos sonhos dos personagens, projeta-os com eles e vibra com seus desejos), e então, finalmente, sentir toda vertigem que se sente, como "quando uma coisa feliz cai"

Interessante notar que, na composição da obra como um todo, há uma espécie de elogio da impermanência e da queda. Então, a dinâmica da microestrutura textual daquele vaivém de histórias que analisamos anteriormente, acaba se alargando nesta macroestrutura narrativa, em que o movimento se resume em subir, ascender, para depois, espetacularmente cair, fechar, terminar.

A idéia do espetáculo do fim é recorrente em muitas das obras de Baricco $^{20}$. Poderíamos citar, por exemplo, a explosão do navio em que morrerá Novecento (Novecento), ou, em Questa Storia, a destruição da gigantesca pista de corrida, construída por Elizavetta, a milionária excêntrica, que a manda fazer, em homenagem a seu amado Ultimo Parri, para, no dia seguinte, mandar destruí-la. Assim, também, como fosse feita de areia, a Estalagem Almayer de Oceano Mare, ao final, "dissolve-se", depois que o sétimo hóspede, o escritor, o que "conta" o mar, vai embora.

Parece-nos, também, muito ilustrativa a história do castelo de vidro, o Crystal Palace. Num primeiro momento, há um movimento ascensional (conforme constatamos anteriormente), um universo que vai se alinhavando, justificando o desenho do sonho, representa a força de vida de Hector Horeau que se concentra inteira na construção de um lugar feito de vidro. O vidro, aqui, é altamente carregado de conotação simbólica (forma recorrente, também, em Novecento, conforme já analisamos, no primeiro capítulo):

Lo capisce?, è la magia del vetro... prottegere senza imprigionare... stare in un posto e poter veder ovunque, avere un tetto e vedere il cielo... sentirsi dentro e sentirsi fuori, contemporaneamente...

\footnotetext{
${ }^{20}$ Ver, a título exemplificativo, o trecho em que se descreve a explosão da locomotiva Novelty, em CR, p.60.
} 
un'astuzia, nient'altro che un' astuzia... se lei vuole una cosa e però ne ha paura non ha che da mettere un vetro in mezzo... tra lei e quella cosa... potrà andarle vicinissimo eppure rimarrà al sicuro... Non c'è altro... io metto pezzi di mondo sotto vetro perchè quello è un modo di salvarsi... si rifugiano i desideri, lì dentro... al riparo dalla paura... una tana meravigliosa e trasparente... Lo capisce, lei, tutto questo? (BARICCO, 1999, p.156)

Na edificação desse sonho, revela-se o desejo de se libertar e, simultaneamente, a urgência de uma necessidade de proteção, diante de toda sorte de medos e limitações do viver. Mais uma vez, outro dos temas recorrentes na obra de Baricco: o dentro X o fora; o interior X o exterior; o limite X o ilimitado; estar preso X ser livre.

Note-se que o sr. Horeau vai ao sr. Rail para encomendar as milhares de folhas de vidro, necessárias à concretização de seu projeto faraônico. O sr. Rail é o dono da fábrica de vidros e seu projeto vital é o da construção de uma ferrovia que viabilize a existência dos trens. Mas mesmo o trem, que, em resumo, se define como o castelo do sonho do sr. Rail é composto por vagões que se abrem ao mundo, por meio de janelas de vidro.

Num e noutro caso, o vidro, essa película transparente que permite a expansão do olhar, do conhecimento do mundo de fora, sem que necessariamente se saia de dentro, representa, também, outro eixo central da ficção do autor, qual seja, o da necessidade de fazer com que o homem reaprenda a ver, readquirindo olhos de ler e de contar o que o circunda (a questão dos múltiplos pontos de vista que remetem a um verdadeiro aprendizado do olhar e que, por sua vez, se reflete nas infinitas possibilidades de narrar, libertando o homem da visão embotada e do peso silêncio, será objeto de análise do próximo capítulo deste estudo).

Voltando ao Crystal Palace, da mesma maneira com que o constrói, com todo glamour que exige um grande castelo, totalmente feito de vidro, que confere às pessoas a sensação de plena liberdade, sem negar-lhes o contato com o mundo lá fora, protegidas e salvas de qualquer intempérie, o narrador, sem abrir mão da eloqüência da glória do que havia sido construído, com tanto empenho e zelo, descreve, minuciosamente sua queda, apelando a recursos estilísticos de intensa força imagética, com o propósito de conferir ao fim, a mesma grandeza do começo. Poderemos afirmar que se estabelece uma poética da vertigem, um procedimento narrativo que se estrutura em torno do eixo gravitacional, brusco e esplendido do que acaba, inevitavelmente, ruindo: 
C'erano otto musicisti che provavano. Era sera tardi, e c'erano solo loro, nel Crystal Palace, loro e qualche sorvegliante. Provavano per il concerto del sabato. Sembrava piccolissima, quella musica, persa in mezzo a quell' enormità di ferro e di vetro. Sembrava suonassero un segreto. Poi una tenda di velluto prese fuoco, nessuno ha mai saputo dire il perchè. Il violoncelista vide con la coda dell'occhio quella strana fiaccola accendersi all'altro capo del palazzo e alzò l'archetto dalle corde. Smisero di suonare, uno ad uno, senza dire una parola. Non sapevano bene cosa fare. Sembrava una cosa da nulla. Due sorveglianti erano corsi immediatamente e si davano da fare per far cadere a terra la tenda. Si muovevano veloci, nelle lingue di luce che le fiamme gettavano tutt'intorno. Il violoncellista prese dal leggio gli spartiti. Disse Forse bisognerà chiamare qualcuno. Uno dei violinisti disse Io da qui me ne vado. Rinfilarono gli strumenti nelle loro custodie e se ne uscirono alla spicciolata. Qualcuno restò indietro a guardare le fiamme che si alzavano sempre più alte. Poi fu un attimo: un aiuola di cespugli, a pochi passi dalla tenda, si accese come un lampo e iniziò a crepitare con ferocia fino a lambire il lampadario a petrolio che pendeva dal soffitto e che cadde con uno schianto così che in un attimo il fuoco parve dilagare tutt'intorno come un groviglio di ruscelli in fiamme lanciato all'impazzata contro ogni altra cosa, in un contagio fulmineo di fuoco e luce e fumo e rovente distruzione. Uno spettacolo. Le fiamme si divorarono in una manciata di minuti quintali di cose. Da fuori il Crystal Palace incominciò a sembrare un'enorme lampada accesa da una mano gigante. In città fu chi si avvicinò alla finestra e disse Cos'è quella luce? Un sordo rumore iniziava a scendere giù dai sentieri del parco e ad arrivare alle prime case. Arrivarono decine di persone, e poi centinaia, e poi migliaia. Ad aiutare, a vedere, a gridare, tutte con la testa all'insù a guardare quello spropositato fuoco d'artificio. Gettavano acqua a barili, si intende, ma niente poteva fermare quella invasione di fuoco. Tutti dicevano Resisterà, perchè non poteva andarsene così un sogno come quello.Tutti pensarono Resisterà , e tutti proprio tutti, si chiesero Come può andare a fuoco una cosa di ferro e di vetro?, già, com'è mai possibile una cosa del genere, non brucia il ferro, non brucia il vetro eppure lì le fiamme si stanno ingoiando tutto, proprio tutto, c'è qualcosa sotto, non è possibile. Non ha senso. E in effetti non aveva senso, proprio nessun senso, eppure, quando la temperatura dentro divenne pazzesca esplose la prima lastra di vetro, che nessuno quasi se ne accorse, non era che una, tra le migliaia, come fosse una lacrima, nessuno la vide, ma il segnale era quello, il segno della fine, e così fu infatti, come tutti capirono quando una dopo l'altra incominciarono a esplodere tutte le lastre di vetro, letteralmente scoppiare in pezzi, schiocchi come 
frustate, seminati nel gran crepitare dell'immenso incendio, volava vetro dapertutto, una cosa incantevole, un'emozione che ti inchiodava lì, nella notte illuminata a giorno, con negli occhi lo sprizzare di vetro dappertutto, tragica festa, uno spettacolo da scoppiare a piangere, lì, su due piedi, senza sapere bene perchè. Scoppiano i diecimila occhi del Crystal Palace. Ecco perchè. E allora fu la fine, solo più un gigantesco rogo che continuò a macinare emozioni per tutta la notte, se ne andava il Crystal Palace, a poco a poco, in quel modo assurdo, ma alla grande, questo bisogna ammeterlo, alla grande. Si fece consumare a poco a poco, senza quasi resistere, e alla fine si piegò in due, vinto per sempre, gli si ruppe in due la spina dorsale, schiantata ferocemente, la grande trave di ferro che lo percorreva tutto, dall'inizio alla fine, si spezzò dopo aver resistito per ore, sfinita, si squarciò con un boato tremendo che più nessuno dimenticherà, lo sentirono anche a chilometri di distanza, come se fosse scoppiata una boma immensa, a sfracellare la notte tutt'intorno, e il sonno di chiunque, Mamma, cos'è stato?, Non so, Ho paura, Non aver paura, torna a dormire, Ma cosa è stato? Non lo so, bambino mio, sarà caduto qualcosa, è caduto il Crystal Palace, questa è la verità, è crollato in ginocchio e si è arreso, sfumato per sempre, saprito, svanito e basta, è andata così, è finito tutto, questa volta per sempre, finito nel nulla, per sempre. Chiunque sia stato a sognarlo, adesso s'è svegliato.

Silenzio. (BARICCO, 1999, p.201-202, grifo nosso)

O simples levantamento semântico de termos hiperbólicos deste fragmento conduz ao espetaculoso, à grandiloqüência do fim do Crystal Palace. São termos, adjetivos, verbos, expressões de exagero (que grifamos acima), que buscam enfatizar o incêndio e a explosão, num quase enaltecimento da surpresa, ainda que amedrontadora e pavorosa, naquela espécie de ternura perturbadora, quase sublime a que se refere Rilke, quando estamos diante do colapso de um sonho (a queda de uma coisa feliz):

- se moviam velozes, nas línguas de luz que as chamas lançavam em tudo em torno;

- depois foi num segundo: um canteiro de arbustos, a poucos passos da cortina, se acendeu como um raio e começou a crepitar ferozmente até a atingir o lustre a petróleo que pendia do teto;

- o fogo parecia se espalhar por toda a parte como um emaranhado de riachos em chama jogado loucamente contra cada outra coisa, num contágio fulminante de fogo e luz e fumaça e incandescente destruiç̧ão... 
A configuração do espetáculo deste incêndio apela radicalmente para o imagéticosonoro, quase sinestésico. Temos a impressão de ver, vibrar, ouvir, sentir a catástrofe. A invasão daquele fogo crescente adquire traços demoníacos: as labaredas aparecem como ágeis línguas devoradoras, que vão engolindo tudo ao redor. É mais que fogo, é um animal selvagem, faminto e ávido, que não poupa nada, nem ninguém. Não há como não perceber aqui a intensidade poética, reiterada pelo ritmo que compõe, especialmente, este fragmento. Assim, por exemplo, observemos as aliterações dos fonemas /l/, /f/ e /k/ em:

Poi fu un attimo: un aiuola di cespugli, a pochi passi dalla tenda, si accese come un lampo e iniziò a crepitare con ferocia fino a lambire il lampadario a petrolio che pendeva da soffitto e che cadde con uno schianto così che in un attimo il fuoco parve dilagare tutt'intorno come un groviglio di ruscelli in un contagio fulmineo di fuoco e luce e fumo e rovente distruzione. (BARICCO, 1999, p.200, marcação em negrito nossa)

A repetição dos fonemas /l/ e /f/, respectivamente, criam as sonoridades do alastrarse do fogo, que se expande ferozmente. Interessante a repetição de /lam/: lampo, lambire, lampadario, que querem exacerbar este "lambire".

A aliteração do fonema /k/, gutural, surdo, duro, seco, pretende configurar, ritmicamente, as sonoridades impactantes, pesadas da queda: che cadde con uno schianto così che....

Na seguinte seqüência, também, a aliteração do fonema /k/ não é gratuita. Vejamos:

Quando la temperatura dentro divenne pazzesca esplose la prima lastra di vetro, che nessuno quasi se ne accorse, non era che una, tra le migliaia, come fosse una lacrima, nessuno la vide, ma il segnale era quello, il segno della fine, e così fu infatti, come tutti capirono quando una dopo l'altra incominciarono a esplodere tutte le lastre di vetro, letteralmente scoppiare in pezzi, schiocchi come frustate, seminati nel gran crepitare dell'immenso incendio, volava vetro dappertutto, una cosa incantevole, un'emozione che ti inchiodava lì, nella notte illuminata a giorno, con negli occhi lo sprizzare di vetri dappertutto, tragica festa, uno spettacolo da scoppiare a piangere lì, su due piedi, senza sapere bene perchè. Sccoppiano i diecimila occhi del Crystal Palace. Ecco perchè. (BARICCO, 1999, p.201) 
Notamos que, nesse parágrafo, cria-se um movimento que parte do "pianíssimo", começa com uma lágrima que ninguém nota, para, afinal, chegar à explosão, ao espetáculo e ali permanecer. A repetição do / $/$ / enfatiza, nesse momento, não mais a queda, como no parágrafo analisado anteriormente, mas sim, a explosão, este "scoppiare in pezzi".

Então, o que se revela nas peculiaridades da arte de narrar em Baricco, é o fato de que não se trata apenas de criar o episódio semanticamente, por meio da criteriosa seleção lexical. Há uma verdadeira construção de sonoridades, de ritmo e movimentos, que compõem sua partitura poética e o clímax do episódio é uma magnífica sinfonia.

O que é muito pontual, também, como traço recorrente nesta obra (conforme verificaremos), é a personificação dessa série de "coisas", dos vários projetos, eleitos pelos personagens, ao longo dos capítulos, tais como, por exemplo, o do trem do sr. Rail, um trem de alma feminina, chamado Elisabeth, trem, cujo "único verdadeiro sentido é o de fazer com que o homem veja o mundo como nunca o viu antes"(BARICCO, 1999, p.78, trad. nossa); ou o do órgão inventado por Pekisch, o humanófono, instrumento musical, formado por pessoas, em que cada sujeito é uma nota, única, singular e individual que deve ser respeitada; ou este castelo de vidro transparente, sonho do sr. Hector Horeau, que visava presentear as pessoas com a liberdade e, ao mesmo tempo, a proteção, tão necessárias para afugentar os medos existenciais.

Assim, no caso específico do Crystal Palace, o que antes aparece como um edifício, projetado pelo raciocínio lógico e pelos cálculos extremamente precisos, exigidos para a junção de tantas infinitas folhas de vidro, sai da condição de matéria, de coisa, de objeto e, poeticamente, vai se humanizando. A matéria adquire conteúdo, a coisa passa a ser dotada de alma (tal como aquele pacote, que logo na abertura do romance, vai deixando a condição de mero objeto, adquirindo feições humanas) E à construção do castelo, materialmente, corresponde o movimento ascensional da edificação do sonho. Não se trata apenas da construção megalomaníaca de mais uma obra qualquer. O personagem, que obsessivamente persegue esse sonho lhe dá uma fisionomia, quase como um Gepetto que, a partir de sua arte, confere vida a um simples pedaço de madeira, numa ode ao poder criativo.

Portanto, desde a sua concepção, o Crystal Palace adquire alma, pois carregado de significado. Também, quando de sua destruição (conforme verificamos), tudo parece tocar o sublime. Daí porque, no trecho acima transcrito, quando a primeira chapa de vidro 
explode, o narrador compara isso tudo a uma lágrima, que ninguém conseguira ver, mas que sinalizava o início do fim. Pois, "explodem os dez mil olhos do Crystal Palace". O Crystal Palace, enfim, explodira em lágrimas... Vale a pena transcrever essa descrição:

E, tal como um ser humano, foi se deixando consumar pouco a pouco, quase sem resistir, e no final se dobrou em dois, vencido para sempre, se lhe rompera em duas, a espinha dorsal, arrebentada ferozmente, a grande trave de ferro que o percorria inteiro, do início ao fim, se despedaçou após resistir por horas, liquidada, se dilacerou com um estrondo que ninguém mais esquecerá, ouviramno a quilômetros de distancia, como se tivesse explodido uma bomba imensa, a esfacelar a noite e tudo em torno, e o sono de alguém... (BARICCO, 1999, p.202, trad. nossa)

E desse momento em diante, o narrador, que detinha as rédeas do contar, como exímio pintor de imagens com palavras, se camufla, dá a impressão de desaparecer, a fim de fazer entrar uma outra voz muito viva, totalmente presentificada, que assume por completo a cena, na voz de uma criança assustada com o estrondo da explosão e que interpela, em discurso direto, a mãe, a qual procura acalmá-la. No texto transcrito acima é a parte, quase ao final, que começa com “... Mamma, cos'è stato?” (BARICCO, 1999, p.202).

Aqui, como já vimos, em outros diversos episódios, reafirma-se o procedimento ficcional de Baricco, na necessidade de abrir a narrativa, a fim de que ela também se esfacele e estilhaçada como o vidro, em mil pedaços, descreva o espetáculo do fim para que possa ser contado, sentido, vivenciado por pontos de vista diferentes. A narrativa se curva sobre si mesma. No caso, a voz fragilizada do menino busca traduzir o susto e valorizar, ao máximo, o tom de oralidade. Esse recurso é obtido, habilmente, por essa brusca quebra na estrutura do narrar, já que a voz que predominava é interrompida, literalmente, como se a segunda voz - a da criança - se sobrepusesse à primeira, com a mesma força caótica e desordenada, com que se superpõem as falas, quando de qualquer conversa ou relato oral.

Por isso é que a seqüência em que a criança inicia o discurso não vem introduzida por nenhum tipo de sinalização de pausa, ou dois pontos, ou outro tipo de letra, como talvez, a grafia em Itálico (da qual ele faz uso, em outros trechos, como marcação do diferente) pudesse revelar. É quase como um grito, que não deixa ouvir nada mais, um ruído estrondoso, paradoxalmente vestido na aparência terna e débil da voz de um menino, que, 
justamente porque desprotegido, parece adquirir a força para romper o discurso original, coerente ao todo fragmentário e trágico, do que se está querendo contar. E sempre, aquilo que arrebata o leitor, capturado, que se comove, no sentido de mover-se com o encantamento das histórias que se abrem nesse leque infinito, já que era "una cosa incantevole, un'emozione che ti inchiodava li" ("uma coisa encantadora, uma emoção que te prendia ali”) (BARICCO, 1999, p.201, trad. nossa)

Não parece ser outra a estratégia de composição no trecho mencionado, a de superposição de vozes que aparecem de modo muito espontâneo, quase imperceptíveis, no todo da narrativa: as falas dos músicos que percebem o fogo que se alastra. Nesse caso, parece que seus comentários, até para reafirmar a força do incêndio, determinam o tom de oralidade destinado a presentificar o fato, testemunhá-lo, como se, a todo momento nos fosse dito: - É verdade, eu vi, eu estava lá!!

É o que acontece, por exemplo, em :

Il violoncellista prese dal leggio gli spartiti. Disse Forse bisognerà chiamare qualcuno. Uno dei violinisti disse Io da qui me ne vado. Rinfilarono gli strumenti nelle loro custodie e se ne uscirono alla spicciolata. (BARICCO, 1999, p.200, grifo nosso)

Esse procedimento consegue atualizar o ocorrido, como se tudo estivesse acontecendo naquele preciso instante. E o que se obtém com isso é, também, de certa forma, um perdurar do que se conta ali, um permanecer no vibrato da corda daquele instrumento, aguçando a percepção intensa dos sentidos, em detrimento do que virá depois, das sonoridades que se anunciarão na próxima frase da partitura:

In città ci fu chi si avvicinò alla finestra e disse Cos'è quella luce?... Tutti dicevano Resisterà, perchè non poteva andarsene così un sogno come quello. Tutti pensarono Resisterà, e tutti, proprio tutti, si chiesero Come può andare a fuoco una cosa del genere, non brucia il ferro, non brucia il vetro eppure lì le fiamme si stanno ingoiando tutto, proprio tutto, c'è qualcosa di sotto, non è possibile. (BARICCO, 1999, p.201, grifo nosso) 
Em ambos os casos, a introdução das falas, ocorrem apenas pelo uso da letra maiúscula.

Voltando à décima elegia de Rilke, escolhida propositalmente pelo autor, é preciso apontar a outros significados a que ela remete. Assim, vale conferir o que Dora Ferreira da Silva comenta:

A décima elegia é justamente essa afirmação jubilosa e vibrante da Dor, "nossa folhagem de inverno, nossa pervinca sombria, uma das estações do ano secreto", isto é, da existência humana como interioridade. Esse canto transfigurado que ascenderá até os Anjos aprovadores não é a expressão da simples alegria que brota dos aspectos amáveis da existência, mas é o poderoso canto fecundado pelas "noites de aflição". "O caminho da verdadeira vida", diz Angelloz, "atravessa a dor. A décima elegia será verdadeiramente a evocação da senda que o homem deve seguir para alcançar o real pelo sofrimento: essa senda o conduz da cidade à campina, e, através do reino das Lamentações, até a montanha da Dor Original".(2001, p.122)

Convém, então, ressaltar esse aspecto dos transtornos, dos sofrimentos íntimos pelos quais passam os diversos personagens deste romance, suas "noites de aflição".

Ora, o próprio título Castelos de Raiva, remete à idéia de algo que se edifica ao redor da dor, dos sentimentos conflitantes da existência, em nada, amenos. São sonhos construídos não apenas plasticamente. São quimeras, que se vão concretizando, ao ritmo das paixões. E à ruína real dos castelos concretos de cada um, corresponde um romper-se por dentro: a desilusão e o desencantamento diante das quedas que a vida propõe, almas de cristal partidas que, mesmo coladas, jamais serão as mesmas que foram à época dos sonhos. Há uma correspondência entre o desmoronamento da matéria e do sonho, enquanto ilusão de cada um. Assim é que, fechando a história da explosão do Crystal Palace, de modo conciso, quase num sussurro, aparece a voz narrativa do sr. Rail, confissão abrupta de um segredo muito doloroso de contar:

Poi il signor Rail posa il tagliacarte e dice

-Un giorno... un po' di giorni prima che morisse... io ho visto Mormy... io

ho visto mio figlio Mormy fare l'amore con Jun.

Silenzio. 
bellissima.

- Lei stava sopra di lui... si muoveva lentamente ed era Silenzio.

Il giorno dopo Hector Horeau partì. Il signor Rail gli regalò un tagliacarted'argento. Non si sarebbero mai più visti. (BARICCO, 1999, p.202)

O que ele revela, em apenas duas falas a Hector Horeau - que acabara de ver seu sonho, o palácio de cristal ruir — é a sua dor que se coloca sem nenhum tipo de adjetivação, sem nenhum apelo a sentimentalismos de mágoa, raiva ou desespero. Porém, é essa revelação curta, nua e crua, totalmente despojada, que intensifica o trágico da situação, potencializada pela falta de julgamento explícito, numa espécie de frieza-quase defesa, mas que, por si só, diz tudo, sobre a dor de um homem que assiste ao próprio filho relacionandose com sua esposa, Jun. O dilaceramento da alma do sr.Rail se compõe na seqüência imediata à explosão do castelo de vidro.

Em termos estruturais da narrativa, temos, a princípio, duas situações que, aparentemente, não se tocam, parecendo pertencer a universos distantes. De fato, uma delas se refere ao projeto do sr. Horeau, outra à história pessoal do sr. Rail. Mas o que as une intimamente é a dor da destruição do sonho.

Na primeira, uma estrondosa explosão; na segunda, um desabafo contido, como um golpe curto e aniquilador, semelhante a tantos que o destino nos confere fatalmente, com sua foice silenciosa, porém, certeira (observe-se aqui a repetição de "Silenzio").

Outro trecho muito ilustrativo, nesse sentido, é aquele em que a $\mathrm{sr}^{\mathrm{a}}$ Rail, tendo descoberto que seu marido a traíra, inclusive trazendo consigo, da última viagem, a prova daquele ato, o filho Mormy (pelo qual ela se apaixonará), consegue se relacionar intimamente com o marido, num tipo de revelação extremamente complexa de todos os sentimentos contraditórios de ciúme, raiva, e profunda dor que lhe devastam. Aqui, a voz do narrador, busca descrever a erupção dos sentimentos que passam a aflorar na alma daquela mulher, a partir do inconsciente, que vai se liberando, numa linguagem em que amor e ódio misturam-se à radicalização de um eros violento, vitalmente abalado, essencialmente ferido, que busca sobreviver ao peso da indignação da verdade dos fatos. Seu gestual, suas atitudes crescem no sentido do exagero erótico, para esconder a contenção do choro que, represado no aprisionamento daquela descoberta, não consegue sair. Uma dor 
encerrada no cárcere da decepção, da humilhação não subserviente (pois mesmo sentindose minúscula, Jun permanece altiva, mantendo a pose aparente). Um misto de violência e ternura, de força e compaixão, Tanatos e Eros configuram a densidade deste parágrafo:

- Ascoltami, Jun... guardami e chiedimi quello che vuoi...

Ma Jun non disse nulla. Semplicemente, senza che un solo angolo del suo volto si muovesse, e assolutamente in silenzio, iniziò a piangere, in quel modo che è un modo bellissimo, un segreto di pochi, piangono solo con gli occhi, come bicchieri pieni fino all'orlo di tristezza, e impassibili mentre quella goccia di troppo alla fine li vince e scivola giù dai bordi, seguita poi da mille altre, e immobili se ne stanno lì mentre gli cola addosso la loro minuta disfatta. Così piangeva, Jun. E non smise mai, nemmeno per un attimo, mentre le sue mani spogliavano il signor Rail, e nemmeno dopo, a vederlo nudo sotto di sé e a baciarlo ovunque, non smise mai, continuò a sciogliere il grumo della propria tristezzza in quelle lacrime immobili e silenziose - non ci sono lacrime più belle mentre stringeva tra le mani il sesso del signor Rail e lentamente passava le labbra su quella pelle liscia e incredibile - non c'erano labbra più belle - e piangeva, in quel suo modo invincibile, quando aprì le gambe e in un istante, un po' con rabbia, prese il sesso del signor Rail dentro di sè, e dunque, in certo modo, tutto il signor Rail dentro di sè, e puntando le braccia sul letto, guardando dall'alto il volto dell'uomo che era andato dall'altra parte del mondo a scopare una donna bellissima e negra, a scoparla con così appassionata esatezza da lasciare un bambino nel ventre, guardando quel volto che la guardava prese a rigirare dentro di sé la vinta resistenza che era il sesso del signor Rail, a rigirarlo e domarlo perdutamente, perchè entrasse ovunque, dentro di lei, e ritmicamente scivolasse nella follia, mai smettendo di piangere se quello si può chiamare semplicemente di piangere - eppure con sottile e sempre maggiore violenza, e furore forse, mentre il signor Rail le piantava le mani nei fianchi, nell'inutile e falso tentativo di fermare quella donna che si era presa ormai il suo cazzo e con movimenti ciechi ormai gli aveva strappato dalla mente tutto ciò che non era elementare pretesa di godere ancora, e ancora di più. $\underline{E}$ non smise di piangere $=\mathrm{e}$ di tacere - di piangere e di tacere, nemmeno quando lo vide, l'uomo che era sotto di lei, chiudere gli occhi e non veder più niente, e lo sentì, l'uomo che aveva dentro, venire tra le sue cosce piantandole istericamente il cazzo nelle viscere in quella specie di percorssa intima e indecifrabile che lei aveva imparato ad amare come nessun altro dolore. (BARICCO, 1999, p.27-28) 
A seleção lexical, os elementos metafóricos usados aqui pelo autor, corroboram para a descrição poética daquela dor, "que ela havia aprendido a amar como a nenhuma outra." Assim, por exemplo: “... e absolutamente em silêncio, começou a chorar, daquele modo que é um modo belíssimo, um segredo de poucos, choram só com os olhos, como copos cheios até a borda de tristeza...”; “...continuou a derreter o grumo da própria tristeza naquelas lágrimas imóveis e silenciosas - não existem lágrimas mais belas - ...", "nunca deixando de chorar..." - se aquilo se pode chamar simplesmente chorar - ...”(BARICCO, 1999, p.27, trad. nossa)

Os exemplos que selecionamos conduzem a mais uma constatação valiosa para compreender este autor-artesão de histórias. De fato, percebemos que, a cada queda, a cada desmoronamento da coisa em si, corresponde um baque pessoal e íntimo.

Cumpre observar que, no primeiro caso, há um exagero descritivo que pretende gerar os efeitos espetaculares e grandiloqüentes, apocalípticos do que explode, do que vai aos ares, num movimento crescente, exaltado, de expansão centrífuga do eixo da narrativa.

No segundo, há também, uma erupção dos sentimentos, só que o movimento estrutural que os rege, em vez de ser o da explosão, parece mais com o de uma implosão, fazendo a narrativa voltar-se para o centro (numa força centrípeta), e conter-se, numa espécie de recuo, em que todo ritmo e aliterações anteriores, usadas no espetáculo da explosão, caiam para um "lentíssimo" que pretende tocar o silêncio. Por isso, o silêncio (reiterado duas vezes, abrindo os parágrafos e isolado) ronda, por exemplo, a fala do sr. Rail (BARICCO, 1999, p.202) ou o modo silencioso, contido e, ao mesmo tempo, muito intenso de chorar de Jun.(BARICCO, 1999, p.27)

A maestria na combinação desses dois tipos de movimento está, exatamente, na justaposição dialética dos extremos que o vaivém da agulha do artesão Baricco compõe, sem deixar marcas, vestígios ou costuras aparentes. Recebemos, como leitores, um bordado coeso e firmemente amarrado, reflexo dessa hábil arte de narrar que não quer e nem precisa explicitar os modos com que manuseia seus instrumentos de criação:

Lo capisce?, è la magia del vetro... prottegere senza imprigionare... stare in un posto e poter veder ovunque, avere un tetto e vedere il cielo... sentirsi dentro e sentirsi fuori, contemporaneamente... un' astuzia, nient'altro che un' astuzia... se lei vuole una cosa e però ne ha paura non ha che da mettere un vetro in mezzo... tra lei e 
quella cosa... potrà andarle vicinissimo eppure rimarrà al sicuro... Non c'è altro... io metto pezzi di mondo sotto vetro perchè quello è un modo di salvarsi... si rifugiano i desideri, lì dentro... al riparo dalla paura... una tana meravigliosa e trasparente... Lo capisce, lei, tutto questo? (BARICCO, 1999, p.156)

Além do que procuramos verificar, não poderíamos deixar de mencionar o fato de que tanto em Castelli di rabbia, como em Oceano mare, há uma estrutura semelhante no tocante à narrativa de histórias que conduzem a outras, sucessiva e propositalmente, a fim de que o leitor perca o fio da meada. O incipt e o desfecho importam pouco. O que temos, como conseqüência, é o arrebatamento do leitor desavisado que, conduzido por essa multiplicidade de histórias, contadas por outras tantas vozes narrativas, acaba se perdendo no deleite de ler, quase com a impressão de que está a ouvir, já sem pretensões de saber como será o final ou onde isso tudo vai dar. É preciso fazer perdurar a viagem, permanecer intensamente na travessia. E então, parece-nos inevitável notar o quanto algumas das proposições teóricas de Italo Calvino influenciaram o autor Alessandro Baricco.

De fato, no livro Balene e sogni, escrito em conjunto com Roberto Tarasco e Gabriele Vacis, em mais de uma ocasião, o autor "dialoga" abertamente com algumas das idéias de Calvino. No primeiro capítulo, intitulado "Una frase de Italo Calvino", ele retoma, em interessante trecho, extraído de Città invisibili, o que Marco Polo responde ao Gran Kublai Kan, a propósito do que seria o "inferno":

"L'inferno dei viventi non è qualcosa che sarà.". L'inferno dei viventi è "quello che è già qui, l'inferno che abitiamo tutti i giorni, che formiamo stando insieme".

E conclude, di fronte a un Kublai che immaginiamo certo perplesso, ma forse anche sollevato:

"Due modi ci sono per non soffrirne. Il primo riesce facile a molti: accettare l'inferno e diventarne parte fino al punto di non vederlo più. Il secondo è rischioso ed esige attenzione e apprendimento continui: cercare e saper riconoscere chi e che cosa, in mezzo all'inferno, non è inferno, e farlo durare, e dargli spazio". (CALVINO, 1996 apud BARICCO, TARASCO, VACIS, 2003, p.5) 
Então, quase como se estivesse diante de uma lição que é preciso aprender de cor, Baricco reitera: procurar e saber reconhecer quem e o quê, em meio ao inferno, não é inferno, e fazê-lo durar, dar-lhe espaço. Plenamente consciente de que o inferno é, também o reino da não palavra, da negação de toda e qualquer forma de expressão, das trevas que impedem de ver a luz, da alienação que aprisiona e escraviza o ser, Baricco propõe, em seu fazer literário a resistência ao jugo da sociedade que aliena, emudece a voz e embota o olhar, pela redescoberta da inesgotável fonte de histórias que, de certa maneira, habitam em cada um de nós.

Talvez, seja pertinente recordar, aqui, a monstruosa figura do juiz Minosse, logo à entrada do inferno dantesco, a quem caberá designar a que círculo as almas condenadas deverão descer. Trata-se da figura de um juiz monstruoso, que não fala, mas rosna: "Stavvi Minòs orribilmente, e ringhia".(ALIGHIERI, 2003, p.49)

Contra essa bestialização da ausência da palavra, o imediatismo do massacre da sociedade da informação (que é uma das grandes responsáveis pela morte da narrativa), contra o discurso pragmático, centrado no "para que serve", ele aposta no discurso estético. Faz perdurarem suas histórias, remetendo o leitor "àquilo que não é inferno", porque, no fundo, continuamos marcados pela violência do pós-guerra. Vivemos, hoje, a prisão infernal dos condicionamentos. Robert Kurz é, nesse sentido, bastante contundente, ao definir a atual "sociedade da informação":

Ao que parece, a vida social e intelectual na sociedade do conhecimento - aliás da informação - deve ser levada a um caminho de comportamento que corresponda a um sistema de reflexos condicionados: estamos sendo reduzidos àquilo que temos em comum com cães, pois o esquema de estímulo-reação dos reflexos tem tudo a ver com o conceito de informação e "inteligência" da cibernética e da informática. (KURZ, 2002, p.3)

Para Adorno, uma das maiores violências da sociedade que reifica tudo, está em que:

Apesar do que possam pensar, os seres humanos não são livres; eles vivem na "prisão a céu aberto em que o mundo está se tornando". "Em 
um estado de não-liberdade, ninguém obviamente, tem uma consciência liberada".(ADORNO In LETCHE, 2002, p.200)

O personagem Novecento de Baricco parece saber disso muito bem. Diante da total perplexidade do amigo, que não compreende por que, tendo-se tornado um grande pianista, capaz de ser famoso no mundo, ele opta por permanecer no navio, confinado nos limites da prôa à popa, ele responde:

Se quella tastiera è infinita, allora/

Su quella tastiera non c'è musica che puoi suonare. Ti sei seduto su un seggiolino sbagliato: quello è il pianoforte su cui suona Dio/ Cristo, ma le vedevi le strade?/

Anche solo le strade, ce n'era a migliaia, come fate voi laggiù a sceglierne una/

A sceglierne una donna/

Una casa, una terra che sia la vostra, un paesaggio da guardare, un modo di morire/

Tutto quel mondo/

Quel mondo addosso che nemmeno sai dove finisce/

E quanto ce n'è/

Non avete mai paura, voi, de finire in mille pezzi solo a pensarla?

A viverla.../

E continua:

Non sono pazzo, fratello. Non siamo pazzi quando troviamo il sistema per salvarci. Siamo astuti come animali affamati. Non c'entra la pazzia. È genio, quello. È geometria. Perfezione. I desideri stavano strappandomi l'anima. Potevo viverli, ma non ci son riuscito.

Allora li ho incantati.(BARICCO, 2002, p.57-58)

O que Novecento nos deixa, assim, é um inquieto ponto de interrogação, que destoa dos resignados pontos finais, com que aprendemos a conformar, em silêncio, nossa história. 


\title{
3.2.Castelli di rabbia $X$ Mundos de vidro
}

\author{
"Perseguimos a modernidade em suas \\ metamorfoses incessantes e nunca \\ conseguimos apanhá-la... Ela é o próprio \\ instante, um pássaro que está por toda parte \\ e em lugar nenhum. Desejamos pegá-la viva, \\ mas ela abre suas asas e desaparece, \\ transformada em um punhado de sílabas..." \\ Octavio Paz
}

Gostaríamos de refletir, inicialmente, sobre um aspecto que, num primeiro momento, poderia ser tomado como irrelevante, na análise da obra Castelli di rabbia. Trata-se de como se chegou à tradução do título deste romance para o Português: Mundos de vidro (BARICCO, 1999, tradução de Elia Ferreira Edel, Rio de Janeiro: Rocco,1999).

Nosso propósito não será o de estabelecer uma análise crítica da tradução do título em si, mas o de verificar uma série de questões, que podem ser suscitadas, a partir da observação atenta dos referidos títulos.

Ao optar por Mundos de vidro, o tradutor, de fato, buscou dar conta dos diferentes universos que são construídos ao redor dos projetos existenciais dos personagens, células independentes que convivem, lado a lado, no grande corpus orgânico do romance. Constatamos, sim, a existência desses diversos "mundos" que se configuram como símbolos dos anseios de cada um.

Nesse sentido, por exemplo, o "mundo" do sr. Rail que almeja construir a ferrovia sobre a qual correrá o trem Elisabeth; o mundo de Pekisch, fascinado pelos sons e pela música, cuja busca desesperada é a de tentar saber qual é a sua nota musical, já que todo ser humano possui uma que lhe é própria; o mundo de Pehnt, que precisa escrever tudo para não se esquecer, até que cresça na medida do imenso paletó que o protege, para, crescendo, aprender a viver; o mundo de Mormy, o menino filho do sr. Rail, cujo estranho olhar, remete ao mundo dos lunáticos; o mundo dos que, por possuírem "a sombra de ouro", não se adaptam ao sistema; o mundo fascinante de Hector Horeau, que constrói um Palácio de Cristal - o Crystal Palace - a fim de que o exterior possa ser como que a continuidade do interior; a fim de que todos possam ver o mundo, por meio das gigantescas lâminas de vidro transparente; o mundo da belíssima Jun, eterna esposa, amante do sr. Rail, cujo 
mundo se projeta na perspectiva de poder ouvir/contar infinitas histórias, até o momento de partir, para poder ver o mar.

Todos esses mundos, círculos fechados que se concentram na pulsação dos ideais de busca de cada um dos personagens, tocam-se de modo muito tênue dentro do pequeno/grande reino imaginário de Quinnipak. Tudo é possível em Quinnipak, pois se estabelece, desde o início, com o leitor, a chamada "suspension of desbelief" (COLERIDGE in CALVINO, 2006, p.378) e entramos no jogo, facilmente capturados pelo tom, bastante característico em Baricco, do "Era uma vez..."

Concluiremos, consequientemente, que nada teríamos a contrapor, quanto à escolha semântica de "mundos", a princípio, bastante adequada ao que se pretende contar. Para qualificar que tipos de mundos são esses, o tradutor nos oferece "de vidro" (e não "de raiva", como obteríamos diretamente do Italiano). E até conseguimos perceber a coerência desta escolha, já que todos esses mundos se apresentarão, no desenrolar da narrativa, como essencialmente frágeis, acabando por ruir por completo. Nenhum deles permanecerá, pois, de fato, representam projeções e sonhos que chegam a se concretizar na materialização de "mundos", para em seguida, serem destruídos, espatifarem-se em mil pedaços, porque feitos da matéria frágil, vulnerável e efêmera do "vidro".

Porém, o que nos parece interessante observar é a efetiva distância entre os semas "mundos" e "castelos" (possível tradução direta e literal do italiano castelli), porque o título Castelli di rabbia sugere muito mais do que, à primeira vista, se poderia supor.

De fato, todos os personagens que vão compondo a mágica tessitura dos seres que vivem em Quinnipak, para além de seus projetos materiais, centrados na ânsia de construir (a construção da ferrovia de Rail), pesquisar (os árduos experimentos de Pekisch, em torno da transmissão dos sons), realizar concretamente (a edificação dificílima do gigantesco Palácio de Cristal, do sr. Horeau), estão projetando, na verdade, seus desejos, os mesmos feitos da matéria dos sonhos, das regiões obscuras e sombreadas do inconsciente e das armadilhas angustiantes da mais difícil das viagens, que é a que se faz em busca do eu. Em resumo, eles parecem querer construir seus castelos, não apenas por representarem, numa análise contextual e histórica, em boa medida, a ideologia dos homens empenhados nas grandes edificações de fins de século XIX, no período que se definiu como o da grande aventura da modernidade, mas também como aqueles que carregam a contradição moderna 
em si mesmos, a da consciência de que tudo é evanescente, de que tudo, em pouco tempo, ruirá, enfim, de que "tudo que é sólido desmancha no ar"(BERMAN,1995, p.13)

Há, nesse aspecto, um profundo paradoxo, que bem caracteriza a trágica condição do homem moderno. O novo homem que vai surgindo, a partir, por exemplo, da configuração dos espaços urbanos, como bem ilustram os famosos bulevares parisienses (de fins de século XIX), grandes vitrines em que acabam por se justapor os burgueses, do lado de dentro dos cafés, regozijando-se do luxo e de sua fartura glamourosa, e, ao mesmo tempo, os pobres que, agora, também entram em cena, permanecendo, porém, do lado de fora. Vêm para as luzes do grande show, aparecem também nos novos espaços da cidade, aqueles que, antes, ficavam confinados em suas miseráveis moradias.

Talvez, um dos poetas que melhor tenham captado essa alma da modernidade tenha sido Baudelaire. Em seus famosos poemas em prosa de Spleen de Paris, mais do que constatar a mudança, ele revelou suas complexidades. ${ }^{21}$ Os detritos, agora, passam a conviver com o luxo e a ostentação e não será por acaso que o poeta precisará perder o halo, a fim de buscar a poesia, no lodaçal de macadame, nos lugares mais apoéticos. ${ }^{22}$

É nesse tempo, também, que a engenharia das grandes edificações, como símbolo da criatividade humana, passa a assumir ares de relevo e importância, nos ousados projetos das novíssimas urbes. E tal qual o impacto causado pelos dos bulevares em Paris, assim também e com igual força foi o que acabou acontecendo com a construção do imenso palácio de cristal, projetado por Joseph Paxton e construído em seis meses (utilizando os modos mais avançados de pré-fabricação) no Hyde Park de Londres, para alojar a grande Exposição Internacional de 1851. Foi, em seguida, desmontado em três meses quando a exposição fechou, e então novamente montado, no centro da cidade, numa versão ampliada,

\footnotetext{
${ }^{21}$ Observar, a esse respeito, Os olhos dos pobres (Spleen de Paris, n. 26), em que um casal de amantes, felizes num café do bulevar, passam a ser surpreendidos pelos olhares de uma família de pobres ("uma família de olhos"), o que causa no narrador certo "incomodo", denunciando o mal estar de uma das contradições da modernidade, qual seja a do novo espaço urbano, como fator determinante nas aproximações e convivências, antes, inexistentes.

${ }^{22}$ Em A perda do halo (Spleen de Paris, n. 46), Baudelaire busca satirizar a crença na arte como inspiração divina, fazendo com que o poeta "perca o halo", dessacralizando, assim, a figura do poeta como a de um ser dotado de dons que o diferenciariam dos homens comuns. Aponta, desse modo, a outro forte traço da modernidade:o de que a poesia, a beleza e o sentido do estético pode estar nos lugares mais apoéticos. De fato, os poetas da modernidade se tornarão mais profunda e autenticamente poéticos quanto mais se tornarem homens comuns.
} 
na Sydenham Hill, em 1854, tendo, por fim, desaparecido, num incêndio misterioso em 1936. Vejamos o que nos revela, a respeito, Marshall Berman:

Em sua relação com a natureza, o palácio antes envolve que oblitera: grandes árvores antigas, ao invés de serem cortadas, são contidas dentro do edifício, onde - como uma estufa, a que o palácio se assemelha e que deu fama a seu criador, Joseph Paxton - crescem maiores e mais sadias do que nunca. Além disso, longe de ter sido projetado com árido cálculo mecânico, o palácio de cristal é, realmente, a construção mais visionária e ousada de todo o século XIX. Apenas a ponte do Brooklyn e a torre Eiffel, uma geração mais tarde, fariam frente à sua expressão lírica das potencialidades da era industrial (...) Além disso, os construtores do palácio, longe de apresentarem o edifício como final e indestrutível, orgulhavam-se de sua transitoriedade. (BERMAN,1995, p.225)

Ora, é evidente que Baricco aí se inspirou, quando criou como um dos castelos a serem construídos, o sonho de Hector Horeau, o Crystal Palace.

Importa notar o quanto, em Castelli di rabbia, acabam sendo representados muitos dos temas que reportam a essa aventura da modernidade, seja na descrição minuciosa do aparecimento dos primeiros trens, de sua velocidade e de todo o seu significado, seja na interessantíssima transfiguração, para o reino de Quinnipak, do Palácio de Cristal (totalmente inspirado no Palácio de Vidro de Paxton), que assim como tudo o mais, acabará em mil pedaços.

A propósito, não há como deixar de perceber, no tocante ao surgimento das locomotivas, algo identificado esteticamente com alguns traços do movimento futurista. De fato, a exaltação da máquina e da velocidade, esse espírito exultante na destruição do passado, o culto ao progresso e à celebração da tecnologia, parecem impregnados no encantamento e em certo exagero de imagens que um dos narradores do romance busca ao revelar o deslumbramento, não só da onipotência materializada da locomotiva em si, mas também de algo belo e espetaculoso, como sua explosão. Senão vejamos:

Ma il treno...quello era esatto, era tempo divenuto ferro, ferro in corsa su due binari, sequela precisa di prima e di poi, incessante processione di traversine... e sopratutto... era velocità... velocità. La velocità non perdonava. Se c'erano sette minuti di differenza tra 
l'ora di qui e l'ora di là, lei li rendeva visibili... pesanti... Anni di viaggi in carrozza non erano mai riusciti a scoprirli, un solo treno in corsa poteva smascherarli per sempre. La velocità. Gli dev'essere scoppiata dentro, a quel mondo, come un urlo represso per migliaia di anni. Niente dev'esser sembrato uguale a prima quando arrivò la velocità... Di per sé il treno non sarebbe stata gran cosa, nonera poi che una macchina... Questo però è geniale: quella macchina non produceva forza, ma qualcosa di concettualmente ancora sfumato, qualcosa che non c'era: velocità... Peccato che alla fine esplose, proprio così, esplose — dev'essere magnifico vedere una locomotiva esplodere, la caldaia che si disfa come una vescica rovente, la piccola stretta lunga ciminiera che vola, improvvisamente leggera come il fumo che ha dentro, e poi gli uomini, perchè qualcuno doveva pur esserci alla guida di quella bomba innescata su due binari di ferro, gli uomini anche loro a volare come fantocci, come sbuffi insanguinati, razione quotidiana di sangue per oliare le ruote del progesso, dev'essere magnifico vedere una locomotiva correre, e poi esplodere. (BARICCO, 1999, p.59-60)

E quanto às ferrovias:

"Prima che inventassero le ferrovie la natura non palpitava più: era una Bella Addormentata nel bosco"scrissero. Ma molto tempo dopo, col senno di poi. Ci facevano su della poesia. Al momento, proprio le prime volte che la Bella Addormentata si faceva violentare da quella macchina lanciata a colpevole velocità, fu appunto la violenza che rimase impressa nelle parole e nei ricordi. E la paura. "È davvero un volo, ed è impossibile sottrarsi all'idea che il minimo incidente potrebbe causare la morte istantanea di tutti", così la pensavano. E certo dovette formarsi inconsapevolmente nell'animo un nesso preciso tra quel presentimento di morte e l'immagine distorta che, dal finestrino e a prezzo del rischio di vita, il mondo tutto offriva di sè. Come ai morti, a cui passa negli occhi in pochi istanti tutta una vita, sfilando via veloce. A quelli sfilavano via prati, persone, case, fiumi, animali...

Bisogna immaginarselo, la paura da una parte e quel bombardamento di immagini dall'altra, o meglio una, la paura, dentro l'altro, il bombardamento, come onde concentriche di un unico soffocamento, angoscioso, certo, ma anche... qualcosa come un improvviso squarciarsi della percezione, qualcosa che doveva avere dentro la scintilla di un qualche bruciante piacere - un avvitamento progressivo del ritmo delle percezioni, dalla lenta partenza alla corsa incondizionata dentro alle cose, tutto un protocolo vertiginoso di immagini che si affastellano in disordine 
pigiandosi negli occhi, ferite incurabili nella memoria, e schegge, strisciate di passaggio, fughe di oggetti, polvere di cose - questo doveva essere piacere, perdio- "intensificazione della vita nervosa", l'ha poi chiamata Simmel - sembra un referto medico - e in effetti ha il profilo, e il sapore, della malattia, quell'ipertrofia del vedere e del sentire... (BARICCO, 1999, p.62)

O exagero na escolha dos termos descritivos colabora para pintar esse quadro frenético, de violenta exuberância, tanto no primeiro, quanto no segundo trecho.

No primeiro, o culto à velocidade e à beleza da explosão. No segundo, a narrativa precisa, ao tentar representar, do modo mais fidedigno, a "intensificação da vida nervosa", uma exacerbação dos sentidos, a partir do que o movimento desenfreado dos vagões do trem provocava.

Essas imagens são tão fortes que, ao tratar do medo, de um lado e da exigência das percepções de outro, fazem-nos tocar quase que as situações limítrofes entre a vida e a morte. Como se, todos os sentidos, a partir do estímulo provocado pela velocidade, com a sequiência fragmentada, ilógica e ininterrupta das múltiplas visões que se sucedem, desfilassem, diante de nossos olhos extasiados e sempre alertas, o caos excitante da memória, nos últimos momentos que antecedem a hora derradeira.

Temos algo semelhante (guardando as devidas proporções) dessa apologia à velocidade e ao progresso vertiginoso, por exemplo, em alguns trechos do Primeiro Manifesto Futurista :

Um imenso orgulho enchia nossos peitos, ao nos sentir os únicos em pé, como os faróis ou como as sentinelas avançadas, face ao exército de estrelas inimigas que acampam nos seus bivaques celestes. A sós com os mecânicos nas clareiras infernais dos grandes navios, a sós com os negros fantasmas que se mexem no ventre vermelho das locomotivas desvairadas, a sós com os bêbados que batem as asas contra as paredes! (...)

4. Nós declaramos que o esplendor do mundo se enriqueceu com uma beleza nova: a beleza da velocidade.(...)

11. Nós cantaremos as grandes multidões movimentadas pelo trabalho, pelo prazer ou pela revolta (...) as locomotivas de grande peito, que escoucinham os trilhos, como enormes cavalos de aço freados por longos tubos, e o vôo deslizante dos aeroplanos, cuja 
hélice tem os estalos da bandeira e os aplausos da multidão entusiasta. (TELES, 1978, p.83, 85-86)

Além das figuras hiperbólicas que coincidem com a ousadia, com o culto à tecnologia e ao avanço ao futuro e com a ruptura radical contra tudo que significasse tradição e passado, nesse manifesto, percebe-se, claramente, a metamorfose da máquina. No caso das locomotivas, estas adquirem, por exemplo, as características de cavalos de aço que, revoltados, dão coices nos trilhos.

Como não associar essas "locomotivas desvairadas" de "ventre vermelho", "a sós com os bêbados que batem as asas contra as paredes!" do manifesto futurista, à vertiginosa explosão da locomotiva em que "a caldeira se desfaz como uma bolha ardente" e "os homens também vão voando como fantoches, como golfadas ensangüentadas, ração diária de sangue para lubrificar as rodas do progresso"? (BARICCO,1999, p.54)

É da essência do que é moderno esse movimento de ascensão e queda conscientes, assumindo a vertigem da queda como bela e estética, tal como o poeta que sabe buscar poesia no feio, no grotesco e nos lugares considerados apoéticos. Pertence à condição da modernidade o que está em constante crise e mutação, o que é impermanente e, talvez nisso esteja, também, um dos traços fundamentais que constituem o ser moderno, qual seja, o de não se relacionar de maneira apocalíptica com o passado, lamentando aquilo que não volta mais, mas o de se apropriar dele, numa atitude transformadora.

Vale a pena, ainda, mencionar um dos mais importantes retratos dessa contradição moderna, que toca de perto a catástrofe e não pode mais se desvencilhar do que está, vertiginosamente, a caminho: o que passou a ser entendido como "progresso". Trata-se do comentário feito por Walter Benjamin, a propósito do quadro Angelus Novus de Paul Klee (1932):

Nele está representado um anjo, que parece querer afastar-se de algo a que ele contempla. Seus olhos estão arregalados, sua boca está aberta e suas asas estão prontas para voar. O Anjo da História deve parecer assim. Ele tem o rosto voltado para o passado. Onde diante de nós aparece uma série de eventos, ele vê uma catástrofe única, que sem cessar acumula escombros sobre escombros, arremessando-os diante dos seus pés. Ele bem que gostaria de poder parar, de acordar os mortos e de reconstruir o destruído. Mas uma tempestade sopra do Paraíso, aninhando-se em suas asas, e ela 
é tão forte que ele não consegue mais cerrá-las. Essa tempestade impele-o incessantemente para o futuro, ao qual ele dá as costas, enquanto o monte de escombros cresce ante ele até o céu. Aquilo que chamamos de Progresso é essa tempestade. (BENJAMIN, 1985, p.157-159)

Nosso autor tem plena consciência disso e, ao eleger como temas centrais de seus enredos, alguns dos que mais evidenciam esses "tempos modernos", demonstra o quanto é atilado com a problemática que se coloca em nossa realidade hoje, fruto de toda convulsão iniciada na virada do século XIX para o XX.

Daí a importância de serem "castelos" (e não apenas mundos) o que esses personagens constroem e almejam. Pois tal como os edificam, ao mesmo tempo, será nesses castelos que irão se deparar com o vazio, com a busca do objeto impalpável de seus desejos, que resultará em nada, porque, inevitável a queda, a desilusão.

Cada um desses castelos parece representar a metáfora do desejo e da decepção, para além da matéria bruta de sua concretização no mundo. Nesse sentido, os castelos são edificados não apenas no plano da realidade, mas da ilusão. E aqui, não podemos deixar de nos lembrar do castelo do mago Atlante, de Orlando Furioso, reino encantado do desejo e do engano, metáfora da existência humana, que sempre se volta a miragens vãs, determinada pelo imponderável e imprevisível. No palácio encantado:

Il desiderio è una corsa verso il nulla, l'incatesimo di Atlante concentra tutte le brame inappagate nel chiuso d'un labirinto, ma non muta le regole che governano i movimenti degli uomini nello spazio aperto del poema e del mondo. ${ }^{23}$ (CALVINO, 2007, p.172)

Assim sendo, o velho mago Atlante, especialista em criar ilusões, leva o ilusionismo à máxima potência em seu castelo. Este será como que um espaço desertificado quanto àquilo que se procura, porém povoado de seres que estão "à procura".

Parece-nos que, em boa medida, os narradores de Castelli di rabbia conduzem-nos, tal como Atlante, muito mais do que a seus "mundos", a seus "castelos" de desejos e

\footnotetext{
${ }^{23} \mathrm{O}$ desejo é uma corrida para o nada, o feitiço de Atlante concentra todas as cobiças insatisfeitas no labirinto inacessível; entretanto, não muda as regras que governam os movimentos dos homens no espaço aberto do poema e do mundo.( trad. nossa)
} 
ilusões, no reino encantado de Quinnipak. Verificaremos, por exemplo, a busca do sr. Rail na construção da ferrovia; de Pekisch à procura desesperada da própria nota musical; de Victor Horeau, que se empenha na construção do Crystal Palace, todos eles, na verdade, numa busca incessante do que, no limite, jamais encontrarão (pois a matéria-prima do sonho é fugidia, tal como o desejo e os anseios mais íntimos que habitam o inconsciente).

Para além dessa apologia dos grandes feitos e empreendimentos modernos (retrato de uma época) tais como, a febre da velocidade dos primeiros trens; a onipotência admirável de uma grandiosa edificação, como a do palácio de vidro, há outro tipo de inquietação. É, por exemplo, o que busca, em essência, o sr. Rail: a preservação da mulher amada, Jun, por isso conta-lhe infinitas histórias e promete presenteá-la com um trem que, um dia, a pudesse conduzir a um lugar de onde se visse o mar. Pekisch, por sua vez, com seu desejo de encontrar, no fundo, a marca do indivíduo, o respeito ao que constitui cada ser humano (como forma de resistir ao massacre da homogeneização do ser, na sociedade massificada), o que o diferenciaria dos demais, na criação do Humanófono, instrumento semelhante a um órgão, constituído, porém, de teclas humanas, cada qual quando "tocada", emitindo a própria nota, única e singular. O sr. Horeau que (após uma irreparável perda amorosa) buscava um projeto faraônico, na construção de um imenso castelo de lâminas de vidro que revelariam a ânsia inconsciente de uma comunicação mais transparente entre as pessoas, de um mundo menos enclausurado e mais aberto, onde o vidro pudesse significar não um anteparo, mas a aproximação, a integração homem-natureza-mundo.

Porém, tal como os personagens sempre "à procura" no castelo de Atlante, analogamente, os desses castelos de Baricco, continuarão "à procura", já que terão seus desejos frustrados.

Esse ilusionismo fica muito claro, quando nos deparamos com a última parte do romance.

Ao final, o verso da epígrafe de Rilke, que abre o excerto, é assim traduzido: “... quando uma coisa feliz cai...”. É quase que um aviso: “atenção, tudo que era ilusão, agora, desmoronará...” E, de fato, é o que acontece.

Pela primeira vez, em toda a obra, surge uma narrativa, em primeira pessoa, datada, como se fossem páginas de um diário confessional. Tudo se passa, então, dentro de um navio, o transatlântico Atlas, no dia 14 de fevereiro de 1922 (portanto, no início do 
séc.XX). É uma voz feminina (num tom realista - totalmente dissonante com o resto do romance) que conta de toda tristeza, angústia e desgaste da situação de ter tido que se prostituir, a fim de, em troca, poder viajar nessa nave, para fugir de uma vida já insustentável.

Num primeiro momento, tem-se a impressão de que nada daquilo pertence à trama que vinha sendo desenvolvida. Somos, enquanto leitores, induzidos a uma espécie de estranhamento absurdo, como se essa mudança abrupta no tom e forma da narrativa, tal como na enunciação em si, nos apresentasse um nonsense, completamente alheio ao núcleo das histórias que vinham sendo contadas, em torno do reino imaginário de Quinnipak. Somos aturdidos. E damo-nos conta do quanto havíamos sido impregnados por aqueles seres, com os quais convivêramos, em absoluto pacto de credulidade, durante a travessia.

Assim, teremos um primeiro plano ficcional geral, que se apresenta logo, de saída, às primeiras páginas do romance. Neste primeiro plano, estamos muito distantes do que poderia se considerar uma narrativa de teor realista ${ }^{24}$. Ao contrário, como na maioria de suas obras, o autor nos conduz a um universo totalmente imaginário, a uma espécie de reino encantado das histórias do "Era uma vez..." Então, mergulhamos nas diversas camadas ficcionais, completamente distanciados de qualquer ótica que nos pudesse remeter a algo de real. E vamos permanecendo na viagem, ao sabor das diferentes vozes narrativas que compõem o habitat de Quinnipak.

Mas, de repente, nas mãos desse demiurgo artesão do narrar, tudo se reverte, cedendo afinal à força voraginosa do último nível ficcional, que é o último capítulo do romance. Neste nível, a voz que narra é tão dissonante das demais, que se estabelece aqui, em termos de configuração estrutural da narrativa, uma espécie de incoerência interna, como se aquilo tudo não tocasse, em momento algum, o que se contara previamente. Mal comparando, como se um acorde soasse muito distinto dos demais, gerando um ruído diverso, outro tipo de sonoridade que parece destoar da harmonia da composição.

Porém, por mais absurda que possa parecer, essa narradora (quase apocalíptica) tem a intenção explícita de fazer tudo desmoronar, já que o grande eixo romanesco, durante todo o percurso, realiza um movimento ascensional, para em seguida, fazer a apologia da

\footnotetext{
${ }^{24}$ Entendamos "realista" aqui com o sentido mais amplo de narrativa que se aproxima, ao máximo, da representação da realidade enquanto tal, filtrada pela objetividade do discurso.
} 
queda. Então, o ilusionismo levado à máxima potência, na busca desenfreada dos desejos, nos diferentes "castelos", neste último capítulo, parece esvaziar-se, precipitando-se na queda que traduz, pelo modo como se revelam as tristezas, desesperos e o total desamparo de uma mulher que precisa fugir da vala funda do submundo de sua existência, para sobreviver, em algum outro lugar.

Tal como a lava quente e viscosa de um vulcão, a princípio, escondida nas entranhas da terra, esse nível mais realista, dentro do plano ficcional geral, sempre esteve presente, só que oculto, em latência (ardilosamente escondido, sob as demais camadas desse tipo de contar). Esteve lá, sub-repticiamente, sem dar sinal, para exacerbar talvez, ao máximo, os efeitos da devastadora explosão final.

É por isso que, embora saibamos que essa voz narrativa que fecha o romance esteja inserida naquele contexto imaginário (afinal, tudo é ficção), a ilusão de realidade, aqui, assume tons imperativos, que parecem induzir a um total e profundo estado de desilusão.

Assim, do ponto de vista da construção da obra, o eixo primordial da narrativa cumpre seu intento de gerar a ilusão, para afinal, destruí-la, como acontece com a edificação dos sonhos de cada personagem que, ao fim e ao cabo acabarão todos estilhaçados. Este movimento de ascensão e queda, portanto, vai se perfazendo, tanto na micro, como na macroestrutura desse vaivém da agulha que conduz os fios do narrar. $\mathrm{E}$ parece-nos que esta é uma das formas de, em síntese, amarrá-los.

Daí porque notamos essa superposição e intercessão dos diferentes níveis ficcionais que aqui se apresentam como mais um dos recursos procedimentais utilizados, magistralmente, pelo autor que, neste estudo, nos dispomos a analisar.

Enquanto a narradora vai se revelando e revelando certos nomes e índices dessa "nova história”, aparentemente à parte do todo da obra (no limite, tal qual um apêndice), o leitor vai sendo acordado, decepcionando-se, retirado, abruptamente, dos castelos encantados do reino de Quinnipak, por essa espécie de "maga", que agora parece insistir em alertar que tudo aquilo fora mero engano e que a atitude mais sensata será, pois, a de destruir a ilusão. É desse modo que conhecemos, essa voz que sofre e que foge (por não mais ter saída) e que remete à voz da personagem que se escondia sob as peles maravilhosas de Jun Rail, a princesa belíssima do castelo dos Rail, a qual se revelará, afinal como a autora das histórias de Quinnipak. Uma mulher subjugada aos caprichos sexuais do 
capitão do navio em que está viajando, cujo nome é Abegg (o mesmo nome do capitão, enaltecido e honrado pela viúva Abegg, em capítulo anterior, em seu castelo de ilusões). E o que se revela é um realismo cru e desesperado:

Le prime volte, il capitano Abegg si toglieva la divisa, e facevamo l'amore. Mi incrociava sul ponte, mi sorrideva e io scendevo in cabina. Dopo un po' arrivava. Quando avevao finito, alle volte si fermava. Mi raccontava di lui. Mi chiedeva se avevo bisogno di qualcosa. Adesso è diverso. Lui entra e nemmeno si spoglia più. Mi infila le mani sotto i vestiti, per eccitarsi, poi mi fa sedere sul letto e si apre i pantaloni. Resta lì in piedi davanti a me. Si masturba e poi me lo ficca in bocca. Non sarebbe lo schifo che è se almeno stesse zitto. Ma lui deve parlare. Gli si ammoscia se non parla. "Ti piace, eh, troia? E allora succhialo, cagna schifosa, prenditelo in gola, dài, che ti fa godere, stupida troia." Chissà che gusto c'è a dare della troia alla donna che ti sta facendo un pompino. Che senso ha? Lo so benissimo che sono una troia. $\mathrm{Ci}$ sono molti modi per attraversare l'oceano senza pagare il biglietto. Io ho scelto quello di succhiare il cazzo del capitano Charlus Abegg. Un baratto alla pari. Lui ha il mio corpo, io ho una cabina della sua maledetta nave. Prima o poi arriveremo e tutto sarà finito. Questo schifo di merda. Alla fine lui viene. Fa delle specie di ridicoli ruggiti e mi riempie la bocca di sperma. Ha un gusto orrendo. Quello di Tool era diverso. Aveva un buon gusto, il suo. D'altronde lui mi amava, ed era Tool. Così io mi alzo e vado a sputare tutto nel cesso, cercando di non vomitare. Alle volte quando torno di là il capitano se n'è già andato. Senza una parola. Allora penso "É finita, per questa volta è finita", mi rannicchio nel letto e vado a Quinnipak. Me l'ha insegnata Tool questa cosa. Andare a Quinnipak, dormire a Quinnipak, fuggire a Quinnipak. (BARICCO, 1999, p.241-242)

Além disso, agora, já que tudo está ruindo, ela nos conta de onde teria surgido a idéia do nome Quinnipak. Seria fruto de uma brincadeira de Tool, homem a quem ela amava e que lhe teria ensinado a fugir para lá, sempre que as coisas, em volta, ficassem insuportáveis, como quando ele fora preso e olhava para fora e "sentia-se morrer" (BARICCO, 1999, p.224). Nessa ocasião, a primeira em que o prenderam, de dentro do furgão, onde o carregavam para o cárcere, ele teria lido, em uma placa, o nome Quinnipak e, a partir daí, esse teria sido eleito o símbolo do lugar encantado para onde fugir, o lugar do sonho e evasão. 
Somos conduzidos, pela hábil mão dessa narradora anônima, aos bastidores do grande show. As máscaras todas estão caindo... Assim, ela nos conta que, tendo crescido ao lado de Tool, quando pequenos ainda, eles teriam inventado um grande tubo de papelão, pelo qual se comunicavam, contando, um ao outro, os seus segredos. Parece que estamos diante de uma espécie de pista, enquanto leitores, de perceber elementos de contato entre ela e Tool e o tipo de pesquisas que fazem, também, em Quinnipak,com um longo tubo, em busca do som, Pekisch e Penht.

O sr. Rail, o milionário dono da ferrovia sobre a qual correrá o trem Elisabeth, que contava histórias à sua bela esposa Jun, e que, um dia, a levaria num trem para ver o mar, também nos dá a impressão de corresponder a Tool, que acabará sendo preso e voltará alienado, com os olhos profundamente tristes e belos (que lembrarão os olhos do sensível filho do sr.Rail, pelo qual Jun se apaixonará).

Quando Tool acaba preso, sob acusação de ter matado um homem e a notícia sai no jornal, ela lê também a notícia de que um enorme palácio de vidro havia pegado fogo (e essa é a referência ao que acaba sendo transfigurado, anteriormente, como o incêndio do Crystal Palace).

Não há como afirmar, com certeza, nessa camuflagem de correspondências, quem teria se transfigurado em quem, porque tudo é matéria ficcional. Porém, nada do que passa a ser narrado, agora, pode ser gratuito.

De fato, traça-se um elenco de situações que parecem querer demonstrar a origem de onde tudo partiu, talvez, como se fosse necessário esse desmascarar, como se, no jogo, já não houvesse mais nenhuma carta na manga do colete, nada mais a esconder.

Muito subliminarmente, por trás de tudo, notamos uma profunda reflexão metaliterária, na medida em que procuram ser elucidados, por meio do recurso artificioso da escrita da voz narrativa de um diário, os percursos subterrâneos do processo da criação em si (por exemplo, na coincidente transfiguração de alguns nomes de personagens, que já haviam aparecido, ao longo de todo o romance, em outras circunstâncias). No fundo, a profissão de fé da invenção, do ato de criar em si, quer explicitar o emaranhado dos fios que só se vêem no avesso do grande bordado.

Esse procedimento representa um tipo de jogo narrativo, em que esses diferentes níveis da ficção se superpõem e se entrecruzam. 
Assim, ao introduzir, exatamente ao final, uma personagem, narradora, cuja voz é muito distinta das demais, estabelece-se uma ruptura intencional, para distanciar, ao máximo, os primeiros níveis do contar (que acontecem em Quinnipak), do último, que quer contar um segredo: o que significa, na realidade, Quinnipak. E quem nos conta é, supostamente, esta narradora anônima que seria a personagem-autora de toda a história.

Outro interessante artifício, que também embaralha as cartas, nestes níveis do contar é o que acontece, por exemplo, quando um narrador revela a história do encontro de Dann Rail e Jun, na quinta parte, capítulo quatro. Ela estava em Morivar, prestes a embarcar em um navio e partir. Nesse momento, ele a vê e se apaixona, deliberadamente decidido a convencê-la a não ir. Para tanto, decide contar-lhe histórias e será devido às suas intrigantes, sedutoras e infinitas histórias, que ela decidirá ficar e ir viver com ele. Neste episódio, a referência ao livro das "Mil e uma noites" é explícita, porém, quem assumirá as vestes de Sherazade, neste caso, será o sr. Rail.

Depois de entretê-la por duas horas com histórias, um pouco antes que o navio partisse, ela lhe pergunta:

- Ne hai altre, di storie?... di storie come quella del vetro.

- Un mucchio.

- Ne hai una lunga come una notte? (BARICCO, 1999, p.211)

Justamente por haver histórias a contar, o sr. Rail não perde aquela mulher belíssima e a conduz ao reino encantado de Quinnipak.

Mas chegará o momento em que ela deverá partir para ver o mar. É fascinante como ela se despede. Percebemos, neste momento, que o sr. Rail é por ela descrito como aquele anjo interior que, conforme o que se diz, logo no início do romance, é o que nos conta a vida, é o narrador que habita em cada um e que precisa ser ouvido.

Jun, no instante da partida, despede-se das histórias que o personagem Rail lhe contava, criando assim um outro nível ficcional, dentro do plano ficcional maior da obra. Seria como se ela escrevesse aquilo que essa voz (a do sr. Rail), que habita dentro dela, lhe ditasse.

Assim, num primeiro plano, temos a impressão de que é o sr. Rail quem conta as histórias. Aos poucos, porém, percebemos que o sr. Rail é criação de Jun. E, afinal, nos 
damos conta de que Jun parece ser, no fundo, a narradora da última parte, a de vida difícil, que se prostitui para poder viajar no navio do capitão Abegg e partir para a América.

Esse procedimento remete à uma reflexividade literária, de duplicação especular, conhecida como "Mise en abyme". De fato:

Na heráldica, o conceito designa o fenômeno de reprodução de um escudo por uma peça situada no seu centro. André Gide usou-o para referir essa visão em profundidade e com reduplicação reduzida sugerido pelas caixas chinesas ou pelas matrioskas (bonecas russas), promovendo o deslizamento do conceito para o campo dos estudos literários e das artes plásticas em geral.A mise en abyme consiste num processo de reflexividade literária, de duplicação especular. Tal auto-representação pode ser total ou parcial, mas também pode ser clara ou simbólica, indireta. Na sua modalidade mais simples, mantém-se a nível do enunciado: uma narrativa vê-se sinteticamente representada num determinado ponto do seu curso. Numa modalidade mais complexa, o nível de enunciação seria projetado no interior dessa representação: a instância enunciadora configura-se, então, no texto em pleno ato enunciatório. Mais complexa ainda é a modalidade que abrange ambos os níveis, o do enunciado e o da enunciação, fenômeno que evoca no texto, quer as suas estruturas, quer a instância narrativa em processo. A mise en abyme favorece, assim, um fenômeno de encaixe na sintaxe narrativa, ou seja, de inscrição de uma micronarrativa noutra englobante, a qual, normalmente, arrasta consigo o confronto entre níveis narrativos.Em qualquer das suas modalidades, a mise en abyme denuncia uma dimensão reflexiva do discurso, uma consciência estética ativa ponderando a ficção, em geral, ou um aspecto dela, em particular, e evidenciando-a através de uma redundância textual que reforça a coerência e, com ela, a previsibilidade ficcionais.(DÄLLENBACH, 1977, grifo nosso)

Tal como já asseveramos, anteriormente, à multiplicidade de vozes narrativas, que corresponderão às diversas percepções do olhar, também esse jogo dos níveis ficcionais, que se sobrepõem, colaborará para a relativização do ato de contar, o que é bastante característico em Baricco.

Vejamos, a título ilustrativo, o seguinte trecho:

Addio Dann. Addio, piccolo signor Rail. che mi ha insegnato la vita. Avevi ragione tu: non siamo morti. Non è possibile morire 
vicino a te. Perfino Mormy ha aspettato che tu fossi lontano per farlo. Adesso sono io che ci vado lontano. E non sarà vicino a te che morirò. Addio, mio piccolo signore, che sognavi i treni e sapevi dov'era l'infinito. Tutto quel che c'era io l'ho visto, guardando te. E sono stata ovunque, stando con te. È una cosa che non riuscirò a spiegare mais a nessuno. Ma è così. Me la porterò dietro, e sarà il mio segreto più bello. Addio, Dann. Non pensarmi mais, se non ridendo. Addio. (BARICCO, 1999, p.213)

Procedimento análogo se dá em outra obra do autor, Oceano mare. Neste romance, há um personagem, bastante misterioso, que só acabará se revelando, ao final, o hóspede do sétimo quarto da Estalagem Almayer (que acabará por desaparecer) e que será identificado como aquele que "diz o mar". Mais uma vez, o personagem-escritor se identificará com o contador das histórias que, por significarem a vida, jamais morrerão.

Não poderíamos deixar de lado a simbologia a que pode remeter, nestes casos, o número "sete". Constatamos, a escolha desse número, ou para indicar a parte final do romance, como acontece em Castelli di rabbia ou para indicar o número do aposento de um dos personagens de Oceano mare, coincidentemente, o mais misterioso.

O "sete", além de ser considerado um número sagrado, é:

o número do ciclo completo, da abundância e da plenitude. Ele agrega em si o simbolismo celeste do três e o significado simbólico terreno do quatro. O budismo conhece sete céus diferentes. Os chineses relacionavam as sete estrelas da Ursa Maior às sete aberturas do corpo e às sete aberturas do coração humano. $\mathrm{Na}$ Antiguidade (incluindo-se o Sol e a Lua) eram conhecidos sete planetas, vistos como divinos e como expressão visual da ordem cósmica. Para os babilônios, havia também os "Sete Males", um grupo de sete demônios que aparecem quase sempre juntos. $\mathrm{Na}$ Grécia, o sete consagrado a Apolo, entre outros, desempenhava um importante papel; bastante conhecidos são: as sete (ou três) Hespérides, as sete portas de Tebas, os sete filhos de Hélio, os sete filhos e as sete filhas de Níobe, os sete sábios, os sete contra Tebas, etc. Muito famosas são as "sete maravilhas do mundo", o conjunto de obras arquitetônicas mais esplendorosas da Antiguidade. No judaísmo, o sete é um número a que se refere o candelabro de sete braços. Na Bíblia, encontra-se o sete várias vezes, tanto na acepção positiva como na negativa; contudo, sempre como expressão de uma totalidade.(...) Também nos contos de fadas e nas traduções populares o sete desempenha um importante papel como número 
da totalidade: sete irmãos, sete corvos, sete cabritos, sete diferentes pratos nos dias especiais, etc. (LEXICON, 1990, p.183)

Como verificamos, anteriormente, em CR, a última parte é a sétima. Tudo indica, conforme as análises já feitas que o movimento desenvolvido ao longo de toda narrativa, agora, sofrerá uma drástica ruptura. É, de fato, o momento fatal, do gran finale e não deixa de haver, nesse sentido, algo de apocalíptico, mas, como em todos os outros momentos de destruição, também esplendoroso (seja na explosão da locomotiva, seja no incêndio do palácio de vidro, seja na explosão do transatlântico Virgínia, em NV; seja no desaparecimento da estalagem Almayer, em OM), segundo nos informa o narrador que assiste a estas explosões. Então, tudo que se completa, que acaba, que, de alguma maneira, fecha um ciclo, pode ser anunciado pelo número sete.

Mas, a personagem-narradora deste último capítulo não parece ser apenas a que finaliza a obra com uma grande revelação. Neste caso, esta sétima parte, também quer remeter a alguma transcendência. Para além do que aqui vai se finalizando, como fechamento perfeito do ciclo do infinito rol de histórias contadas, há a importante confissão de que, em quaisquer circunstâncias impostas pela vida sejam as da miséria, da injustiça, da angústia e do caos insustentável, ainda assim, ela escreverá (no caso específico, escreverá para Elena, uma menina que vivia no mesmo bairro que ela), como modo de salvar-se de todo e qualquer tipo de inferno existencial.

Analogamente, o personagem misterioso de OM, o hóspede do sétimo quarto da estalagem Almayer, será aquele que trará a salvação, quando tudo ruir e desaparecer. Pois, o ciclo já se cumpriu, mas, ele detém o poder de "dizer o mar" e ficou lá naquele quarto (o sétimo), "esse tempo todinho, para dizê-1o"25. E enquanto houver quem consiga narrá-lo, ele se preservará e continuará a existir. Também, aqui, notamos essa reflexão metaliterária que vê, no poder de narrar, uma forma de salvação.Também, neste caso, como no que acontece em CR, assevera-se, para além do fim de tudo, para além das explosões, dos incêndios, dos desaparecimentos, dos castelos tragados pelas ondas do mar ou da realidade, a crença em que algo permanece, porque a missão do ficcionista é fazer permanecer, de alguma forma a matéria que, inevitavelmente, se desfaz, conferindo um sentido maior,

\footnotetext{
${ }^{25}$ Verificar, a propósito, o interessante diálogo entre esse personagem e a menina Dira, à p.220- 221, de Oceano mar.
} 
capaz de resgatar o que de humano nos vai sendo extirpado, numa sociedade em que tudo se transforma em coisa, em que tudo acaba perecendo.

O sete, tanto num, como noutro caso, parece indicar o fechamento do ciclo, mas também uma espécie de síntese entre o sagrado (três) e o terreno (quatro), pois, ainda que a matéria seja destruída, resta esse poder transcendente da permanência, por meio do contar, pois quem conta histórias não morre jamais.

É o que já anunciara anteriormente Novecento: "Non sei fregato veramente finchè hai da parte una buona storia, e qualcuno a cui raccontarla".("Você nunca se dará mal, desde que tenha uma boa história e alguém a quem contá-la”.) (BARICCO, 1994, p.17, trad. nossa).

Sabemos, enfim, que estamos diante de um texto literário e sabemos que estamos diante de um universo inteiramente ficcional. Por meio destes procedimentos, nosso autor traduz sua imensa habilidade de ficcionista.

Ainda é necessário ressaltar que o efeito que se obtém, nesta última parte do romance, fornece-nos a impressão de que a urdidura das histórias anteriormente construídas, agora, precisa despencar, tal como quando caem as cortinas do grande espetáculo.

Porém, estejamos alerta, pois tudo pode ser outra das infinitas armadilhas de Baricco, a fim de nos fazer presas de sua arte. Afinal, esta é mais uma de suas obras abertas, sujeitas a múltiplas interpretações.

Além de tudo o que tentamos demonstrar, faz-se necessário lembrar que a necessidade da construção dos castelos parece estar ligada à nossa busca desesperada de fuga do que seria insuportável, se não tivéssemos reinos como os de Quinnipak ou os de Atlante para fugir, quando descêssemos aos nossos infernos existenciais.

Quinnipak representa uma saída, assim como, para Baricco, a revitalização do ato de contar histórias representa uma resistência aos condicionamentos da realidade que aliena e aprisiona.

Os "castelos", portanto, muito mais do que "mundos", especificariam as ilusões, aquilo que se constrói, tanto no plano material, quanto mental, como a plenitude ascensional da fuga, da evasão, remetendo às infindáveis histórias que se contam, de modo a suportar o fardo de viver. 
Contudo, os "castelos" não são apenas "de vidro", pela simples verdade de que, fatalmente se romperão em pedaços. São castelos "de raiva", pois em sentido contrário aos criados pela ilusão, a crueza que se revela na lida de uma vida difícil, violenta e à margem, da narradora da, sétima e (não por acaso) última parte do romance, aponta para uma insustentável vida, cuja única válvula de escape é fugir, por meio da fantasia, da imaginação, das histórias que ela mesma cria, escrevendo, ficcionalizando para não sucumbir.

Todos os castelos do romance são, de certo modo, de vidro, pois se quebrarão. Mas são também castelos símbolo de desejos e decepções, de projeções de sentimentos, sonhos, frustrações, angústias, de dor e raiva, diante da impotência das agruras que condicionam e aprisionam os seres.

Esta última parte tenta reconduzir a ilusão à sensatez, reduzindo, dentro dos diferentes planos ficcionais, o sonho à condição de realidade. Quinnipak, afinal, fora recriado pela pena desta narradora anônima, confessa autora do romance, que jamais desistirá de escrever, pois acredita que só assim, ouvindo e contando histórias, poderá recuperar algo de humano que, a cada dia, de alguma forma, às vezes violenta e hostilmente, nos vai sendo sonegado.

Por trás dessas infinitas vozes, o autor-artesão continua a crer no seu primeiro mister: extrair daquilo que representa o inferno, o quê e quem não o é, e fazê-los permanecer, durar ${ }^{26} \ldots$ Daí porque ser fundamental encontrar o narrador que habita em cada um de nós, a que alguns chamam anjo e que nos conta, na verdade, a vida, com tudo que ela possa comportar de realidade e de sonho...

Ainda há que se analisar um importante trecho de Castelli di rabbia, em que o ato de contar histórias, assim como o de ouvi-las e o de escrevê-las relacionam-se intimamente à concepção da literatura enquanto resistência. Tal como narrar significa não sucumbir, assim também, nessa mesma linha de reflexão, incluímos o ato de ler. De fato, teremos, aqui, uma belíssima descrição.

De um lado, todo ritmo frenético da velocidade dos trens (conforme já observamos anteriormente) em que, em cada vagão, a partir das janelas de vidro, se sucederão as

\footnotetext{
${ }^{26}$ Esta citação foi literalmente extraída por Baricco da obra "Le città invisibile" de Italo Calvino, à qual ele dedica o primeiro capítulo de seu livro de ensaios, sobre o projeto Totem: "Balene e sogni", já citado anteriormente à $\mathrm{p}$.
} 
múltiplas imagens de fora, contíguas e exigentes, pois todos os nossos sentidos estarão em estado de alerta, super- aguçados nessa sucessão desenfreada de coisas, que trazem os elementos da vida e do mundo de fora para dentro, numa profusão de cores e sentidos quase alucinantes. E em todo momento, as formas do narrar captam a velocidade desta grande viagem dos trens, por meio do ritmo como tudo é descrito pela voz deste exímio narrador, a quem nada escapa. Quase conseguimos ver e ouvir o movimento das locomotivas, nesta música do narrar. E aí é que, como linimento perfeito a essa exacerbação imagética provocada pelos exageros da velocidade, surgirá o ato de ler. Então, teremos, em contrapartida à velocidade do trem, a fixidez, a imobilidade do livro iluminado.

É preciso imaginar o trem velocíssimo, com as janelas que nos colocam em contato com o mundo exterior, a partir do vidro. E dentro, pequenas lanterninhas a iluminar as páginas dos livros que, então, eram, ali, abertos.

Mais uma vez, o dentro e o fora, o micro e o macrocosmo, como uma das fontes inesgotáveis de reflexão de nosso autor. O mundo de fora, aquele que se vê, a partir das janelas de vidro dos vagões ${ }^{27}$; o mundo de dentro dos vagões e o pequeno e fixo mundo, partícula de imobilidade, único ponto de referência, nesse universo totalmente instável e movediço: o livro que se lê.

Afirmará o narrador: "Lê-se para não erguer o olhar para a janelinha, esta é a verdade".(BARICCO, 1999, p.59)

A leitura, aqui, vem definida como modo de superar o medo, a angústia decorrente daquele universo infinito que entrava afoito e onipotente, pela janela, no trem. Talvez, um meio de tentar livrar os sentidos daquela hiper saturação de mundo exterior, que, voraz, não deixa tempo a nenhum tipo de interiorização.

Diante das exigências eloqüentes do mundo exterior, que absorvem e sugam todo nosso sentir, a leitura representaria a pausa, o ponto quieto de solidão necessária. Contra as forças centrífugas e imperiosas da velocidade do mundo lá de fora, que deixam nossos

\footnotetext{
${ }^{27}$ Aqui, mais uma vez, a importante função do vidro (que percorre toda narrativa, especialmente quando da descrição da construção do palácio de cristal) como elemento que separa, mas ao mesmo tempo protege; capaz de por em contato o exterior e o interior; mais do que anteparo, elemento de aproximação.
} 
nervos à flor da pele, um remédio: a chance de um voltar-se para dentro; para dentro da janela do trem; para dentro da janela da vida, para o interior de si mesmos. ${ }^{28}$

Nesse sentido, ler é, também salvar-se. Salvar-se do medo de ser tragado pelo mundo exterior, pela parafernália de imagens e sons que nos bombardeiam todo o tempo, na sociedade que nos aliena e embota nossa capacidade de ter olhos sensíveis. No mundo em que tudo é pretexto para nos afastar de nós mesmos, a leitura se insere no mesmo contexto amplamente defendido por Baricco, qual seja o de resistir.

Assim ele faz o seu elogio à leitura:

Chi può capire qualcosa della dolcezza se non ha mai chinato la propria vita, tutta quanta, sulla riga della prima pagina di un libro? No, quella è la sola e più dolce custodia di ogni paura - un libro che inizia. Così che, insieme a migliaia di altre cose, cappelli, animali, ambizioni, valigie, soldi, lettere d'amore, malattie, bottigli, armi, ricordi, stivali, occhiali, pellicce, risate, sguardi, tristezze, famiglie, giocattoli, sottovesti, specchi, odori, lacrime, guanti, rumori - insieme a quelle migliaia di cose che già sollevavano da terra e lanciavano a velocità prodigiose, quei treni che rigavano avanti e indietro il mondo come ferite fumanti si portavano dentro anche la solitudine impagabile di quel segreto: l'arte di leggere.(BARICCO, 1999, p.66)

Interessante diálogo poderíamos estabelecer entre este trecho de CR e o episódio em que trata da leitura, Italo Calvino, na obra $O$ barão nas árvores. ${ }^{29}$

Neste romance, o menino Cosme, por não se adequar à fechada e obscura vida familiar no reino da Penúmbria, foge e vai viver nas árvores. Passa muito de seu tempo, lendo e percebe que tão importante quanto ler é tentar fazer com que os livros circulem, de mão em mão, pois: “ele considerava os livros como pássaros e não queria vê-los parados ou engaiolados, senão entristeciam.”(CALVINO, 2004, p.119) Mas o que é mais interessante é o fato de que ele conseguirá salvar o mais temível bandido do lugar, por meio da leitura.

\footnotetext{
${ }^{28}$ Essa necessidade de voltar a si mesmo, dessa introspecção, aparece também em Novecento, quando, após decidir não mais sair do navio, ele permanecerá um longo período ensimesmado e sozinho, apenas vendo o oceano, pela escotilha de vidro do grande navio. Parece não ser outra a mensagem que extraímos, a partir do que fala o peixe vermelho do conto La libertà de Buzzati, analisado, neste estudo, no primeiro capítulo.

${ }^{29}$ Esta não é a primeira vez que nos referimos a Calvino, pois é mais que sabido o quanto este autor exerceu influência sobre a obra de Baricco.
} 
João do Mato será "regenerado", a partir do momento em que Cosme, com pena dele (que estava prestes a ser capturado), chama-o para as árvores, para protegê-lo e a fim de fazer um grande bem ao próximo, lhe empresta uma série de livros (que guardava em suas bibliotecas pênseis). O bandido é capturado pelas histórias dos diversos livros que passa a ler compulsivamente. Cosme o "vicia" em livros e ele, que era um homem que fazia o mal, decide permanecer ali, nas árvores, lendo (e conseqüentemente, encontrando algo muito melhor para fazer do que saquear, roubar ou matar)

Porém, após algum tempo, ele vem a ser descoberto e efetivamente preso. Mas, mesmo no momento derradeiro, que o levará à forca, o último desejo é o de que não o separem do romance que, na ocasião, lia: Clarisse.

A fim de realizar a última vontade do bandido João do Mato, Cosme, de cima de uma árvore, aproxima-se da janela da masmorra em que o haviam prendido. E lhe lê, em voz alta, as últimas páginas da história de Clarisse, um pouco antes que ele morra. ${ }^{30}$

Aqui, também, como o que ocorre em CR, o ato da leitura assume um papel redentor. Ler significa salvar-se ou salvar. Quem lê fica imune aos medos do mundo exterior e também aos perigos da existência.

Assim como a narradora do último capítulo de CR que decide escrever à Elena (num gesto altruísta), a fim de resistir às intempéries de viver; assim também, nada estará perdido, enquanto o personagem do sétimo aposento da estalagem Almayer em OM puder contar o mar; assim como a crença de Novecento, em NV, de que estaremos salvos se tivermos uma boa história para contar e alguém para ouvi-la; assim, também, será possível salvar a humanidade do mal, desde que haja livros e histórias que possam ser lidas e/ou narradas, na atitude altruísta de expansão desse mar de narrativas, que não termina nunca e que não sucumbe, nem mesmo, à morte.

\subsection{As máximas de vida: o narrador como conselheiro}

Sem dúvida, um dos traços que marcam o narrador, descrito por W. Benjamin, no ensaio a que já nos referimos anteriormente, é o fato de que: “em qualquer caso, o narrador

\footnotetext{
${ }^{30} \mathrm{O}$ trecho aqui analisado encontra-se às páginas 107-114 da obra mencionada: O barão nas árvores de Italo Calvino.
} 
é um homem que dá conselhos ao ouvinte" (BENJAMIN, 1980, p.59). Importa observar que o conselho não é necessariamente uma verdade impositiva, a assumir ares de veredicto final por parte dos que, por concedê-los aos demais, seriam considerados "superiores". É o próprio Benjamin quem alerta para o fato de que o verdadeiro conselho é o que se colhe na matéria da vida vivida. Só assim, o conselho poderia remeter ao autêntico, à sabedoria.

Ao fazer com que seus diferentes narradores revelem certas máximas de vida, Baricco parece querer atualizar, em parte, a essência desses conselhos que germinam no fecundo campo das experiências pessoais e autênticas dos que são capazes de narrar certas premissas, a partir do que, de fato, viveram.

O respeito ao que cada indivíduo tem para contar (a partir de sua própria experiência) se realiza, por exemplo, nos diferentes tons, acentos e discursos que ele vai conferindo às idiossincrasias, às peculiaridades inerentes a cada respectivo narrador. E as máximas de cada um, suas reflexões sobre os significados da vida, sobre o destino etc, surgem, de modo espontâneo, fluindo naturalmente como conselhos, no âmbito maior da narrativa que se configura como "uma forma artesanal de comunicação". (BENJAMIN, 1980, p.63).

Será, pois, partindo desse pressuposto que o modo de contar da viúva Abegg será totalmente distinto do modo de contar de Kuppert, que em nada se assemelhará à fala de Pekisch, e assim por diante... Estaremos recuperando, de certo modo, a nota que existe em cada um, tal como o Humanófono criado por Pekisch, instrumento formado por teclas humanas, cada qual a emitir um único e próprio som. Desse modo, também, Baricco parece dar conta da necessidade de conferir ao narrador seu traço distintivo, a impressão digital que o torna um indivíduo, o que é bastante coerente a seu projeto inicial de perceber a literatura como forma de resistência ao grande sistema massificado da sociedade contemporânea que homogeneíza tudo e todos.

À multiplicidade de vozes do narrar, em Castelli di rabbia, agregam-se estas peculiaridades de cada narrador que, com suas máximas, tocam de perto os sábios conselheiros das narrativas ancestrais, cuja matéria é tecida, a partir das experiências vividas. Inclusive, a estratégia de criar vários pontos de vista sobre um mesmo fato, enfraquecendo o poder que deteria a voz de um único narrador, vai tecendo um rol de narradores, capazes de aconselhar a seu modo, o que, de certa forma, reitera a crença nessa 
sabedoria mais livre de erudição, em que não há apenas uma verdade, mas verdades que, por serem colhidas no que existe de mais humano são, de alguma maneira, "humanizadas", adquirindo no traço da relatividade sua essência cambiante.

A título exemplificativo, temos algumas frases soltas no discurso fragmentado da viúva Abegg, que as inicia sempre com "Come diceva il mio caro Charlus..." e o modo, bastante simplório e ingênuo, como ela se reapropria dessas chamadas "máximas de vida" e as reconta, no contexto em que imagina ser o mais adequado. Esse tipo de procedimento aproxima o leitor das narrativas orais populares, em que alguém diz algo empiricamente, sem nenhuma pretensão intelectual ou filosófica maior. Mas, por serem frases que passam de uns a outros, na efetiva troca de experiências, desoneradas de aprofundamento psicológico, é que, justamente, permanecem na memória e se traduzem como conselhos, máximas $^{31}$, ditados não por um grande teórico, mas por aquele, cuja experiência se consolidou em sabedoria a ser compartilhada e repartida como pão espiritual. ${ }^{32}$

É interessantíssimo, também, perceber a ironia que impregna as falas da viúva Abegg, que, apenas retoma as frases ditas pelo seu querido Charlus, independentemente do contexto, para conferir algum tipo de seriedade ao discurso. Assim, quando ela dá a Pehnt o imenso paletó que deverá acompanhá-lo até que cresça (preenchendo suas medidas) e possa ir embora, buscar o seu destino, ela lhe diz:

- Ascoltami bene, Pehnt.

(...) Se invece non diventerai abbastanza grande allora resterai qui, e sarai 'comunque felice, perché come diceva il mio caro Charlus "fortunato è il fiore che nasce là dove Dio l'ha seminato". Domande? (BARICCO,1999, p.49)

Em outro momento, quando cai um forte temporal e Pekisch sai à procura de sua própria nota musical, a viúva Abegg descreverá a cena toda e, a certo ponto, dirá:

(...) cioè, io e lei non le sentiamo, perchè lui, il signor Pekisch, lui le sente, e questo se vuole è la radice di tutti i suoi mali, e di quell'inquietudine che lo divora, sì lo divora... diceva che quella

\footnotetext{
31 Valeria, aqui, lembrar importante estudo de Antonio Cândido,em que ele trata dessas "máximas", intitulado "Mundo -Provérbio", num Ensaio sobre "I Malavoglia" de Giuseppe Verga, São Paulo: Revista Língua e Literatura n.1, 1972, p.93-111.

${ }^{32}$ A propósito da permanência das narrativas populares na memória do ouvinte ver p. 62 do ensaio de W. Benjamin: O narrador. Observações sobre a obra de Nikolai Leskow.
} 
nota, quella notte, era appunto una di quelle note invisibili... capisce, quelle che ci sono tra un tasto e l'altro... una nota invisibile perfino per lui... ecco... ma poi non so... io non capisco molto di queste cose... sa cosa diceva il mio caro Charlus? Diceva: "la musica è l'armonia dell'anima", così diceva... (BARICCO, 1999, p.89)

As máximas de Charlus destinam-se, inclusive, para justificar atos pouco condizentes com o discurso da viúva Abbeg, que revela um relacionamento íntimo com o desiludido Pekisch, a título de apoio fraternal.

(....)io credo che Charlus averbbe capito... no, davvero, non lo dico per scusarmi, ma lui era così... lui diceva "la vita è un bicchiere da bere fino in fondo", così diceva... ed era così... l'avrebbe capito... (BARICCO, 1999, p.90)

Além dessas máximas espontâneas, meio empíricas da viúva Abegg, há uma série de outras reflexões, em certa medida, mais elaboradas, profundas, pronunciadas pelos demais narradores, por exemplo, sobre a vida e o destino. Em cada uma delas, a marca, o acento característico daquele que narra. Por exemplo, vejamos o que o sr. Rail, desejoso de construir uma ferrovia, pronuncia sobre o destino:

Sa, è molto bella l'immagine di un proiettile in corsa: è la metafora esatta del destino. Il proiettile corre e non sa se ammazerà qualcuno o finirà nel nulla, ma intanto corre e nella sua corsa è già scritto se finirà a spappolare il cuore di un uomo o a scheggiare un muro qualunque. Lo vede il destino? Tutto è già scritto eppure niente si può leggere. I treni sono proiettili e sono anche loro esatte metafore del destino: molto più belle e molto più grandi. Ecco io penso che sia meraviglioso disegnare sulla superficie della terra questi monumenti alla incorruttibile e rettilinea traiettoria del destino. Sono come dei quadri, dei ritratti. Tramanderanno per anni il profilo implacabile di ciò che chiamiamo destino.(BARICCO, 1999, p.78-79)

Percebemos aí uma descrição muito clara, de alguma forma bem construída, tentando associar a idéia de destino àquela imagem dos trens em movimento. Evidencia-se, nesse 
sentido, a chamada "marca do oleiro", a marca do narrador concentra-se neste discurso lúcido, claro e refinado, que caracteriza o raciocínio lógico e, de algum modo, a inteligência sensível do sr. Rail. Como o sonho deste personagem é o de construir uma ferrovia para fazer correr nela o trem Elisabeth, assim também, em suas categorias mentais, a construção da idéia de destino é formulada, a partir de sua concepção de mundo, de seu fascínio, diante da grande aventura daqueles tempos modernos, quando a velocidade era verdadeira musa inspiradora.

Além do mais, o último propósito da construção da ferrovia, sobre a qual correrá Elisabeth, será aquele de conduzir Jun a Morivar, porto do qual ela deverá partir, quando for o momento de cumprir, igualmente, o seu destino.

Completamente diverso será o modo de narrar o destino desenvolvido por Kuppert. De fato, trata-se agora, de um homem simples, que trabalhava para a família Rail e que atribuirá ao destino o fato de ter sido condenado à forca, por ter assassinado a mulher Mary.

Também aqui, encontraremos um discurso que busca refletir sobre a força inexorável do destino. Mas, agora, em vez da coesão, da coerência e da capacidade de síntese do discurso anterior, teremos a fragmentação característica da confusão mental, que representa a trágica condição de prisioneiro, vítima das atrocidades do que "já está escrito", deste narrador. Ainda que confuso, ele parece alinhavar, com vários outros exemplos, o conceito do que vem a ser "destino", porque tudo e todos estamos inteiramente entregues às mãos onipotentes dessa entidade superior que nos circunscreve e determina. Assim, por exemplo, ele divaga sobre a situação de Pehnt, perguntando quando é que se sabe o momento em que um paletó se torna perfeito (referindo-se ao momento em que Penht deverá ir embora; no caso, o paletó seria a metáfora do destino de Pehnt). Ou ainda, quando é que se pode adivinhar o momento exato em que, assim, do nada, um quadro decide cair ou quando uma pedra imóvel, há anos, acaba se girando sobre si mesma. E, desse modo, acrescentando elementos aparentemente desconexos ao eixo da sua própria história, num crescendo, ele acaba por chegar àquilo que o senhor Rail dizia sobre o destino:

(...) c'è sempre un piano preciso, dietro a tutto... in questo aveva ragione il signor Rail... ognuno ha davanti le sue rotaie, che le veda 
o no... le mie mi hanno portato alla fiera di Trinniter proprio nel giorno giusto... ce n'era a migliaia di giorni, e di fiere.... ma io ci sono finito proprio quel giorno a Trinniter, dove c'era la fiera.... a comprarmi una roncola (...) era proprio Mary... ora dimmi cosa c'entra il caso... cosa mai sarebbe di casuale in una cosa del genere... era tutto studiato, a tavolino... io con la roncola in mano e Mary, dopo anni, che mi sbuca lì...(...) più chiaro di così... rotaie come quelle le vedrebbe anche un cieco... erano le mie rotaie... mi portatono fino a un passo da Mary, in mezzo alla gente, fece appena in tempo a vedermi poi la roncola la sventrò, come un animale.... un mare di sangue.... e le urla, quelle mi suonano ancora in testa adesso, urla così non le avevo mai sentite.... ma anche quelle non avevavo fatto altro per anni che aspettare me... un grido è capace di aspettarti per anni, poi tu un giorno arrivi, e lui è lì, puntuale, terrificante... tutto, tutto è così... tutto quello che incontri è già lì da sempre, ad aspettarti... anche tu, cosa credi? e questa schifosa prigione... tutti fermi ai bordi dei binari, aspettando che io passi... (BARICCO, 1999, p. 165-166)

Percebemos que, por meio desse discurso, o narrador parece eximir-se de toda culpa pelo ato cometido, pois "tudo já estava escrito". Importa observar como essa narrativa vai sendo construída, comentando uma série de fatos paralelos, quase que tergiversando numa retórica, que se constrói gradualmente, com a finalidade explícita de atenuar a culpa daquele que narra.

Se, em vez de um par de tesouras para podar, o destino lhe tivesse colocado nas mãos, flores, então, provavelmente, Mary e ele teriam se reconciliado e aquele crime bárbaro não teria ocorrido. Essa assertiva desloca o sujeito da ação criminosa para o outro onipotente e imbatível, que assume a força implacável das entidades contra as quais o meramente humano nada pode. Em síntese, o grande causador de toda tragédia, o verdadeiro criminoso, nesse contexto, é o destino que conduz a mão do homem, mero instrumento do delito.

Então, evidencia-se que, se, diante do primeiro narrador, associar o destino aos trilhos dos trens é apenas uma bela metáfora, uma idéia, fruto da inteligência analógica de um raciocínio brilhante, diante da angústia do segundo, a face teórica e poética daquela metáfora se reverte, pois este, que passa a narrar, agora (Kuppert), fala de sua experiência como vítima dos trilhos do seu próprio destino. 
Poderíamos pensar, nesse sentido, que, tal como ocorria nas antigas tragédias gregas, em certa medida, a voz narrativa de Kuppert parece recuperar o plano bem traçado e previamente estabelecido para o herói, tipicamente trágico, cujas aventuras e peripécias seriam reduzidas à condição de cartas totalmente dadas pelo destino.

De fato, aqueles heróis poderiam ser caracterizados, em parte, por sua apresentação enquanto seres aproblemáticos, já que tudo estaria pré-determinado, nada lhes restando, senão cumprir o que era proposto, seguindo os passos que lhes coubessem.

Em contrapartida, o trágico na modernidade se concentra exatamente na crise enfrentada pelo herói, diante da avalanche de dúvidas e dilacerações peculiares à sua essência contraditória, a essa marca diferencial, inerente aos seres eminentemente problemáticos.

Mas, se podemos imaginar, na retórica apelativa de Kuppert, algo que o faz parecer tocar as vestes de um herói das tragédias gregas, por outro lado, a consciência angustiante da impotência contra o que é imutável carrega todo o seu discurso e aqui nos deparamos com o conceito de trágico hoje, aquele que de fato, "reflui da exterioridade onde sempre parece ter sido o centro, para o seu núcleo primordial: a Linguagem”.(LOURENÇO, 1994, p. )

A problematização de Kuppert não está no mérito da causa em si, ou seja, não está na constatação da inexorabilidade do que o destino trama, mas na constatação angustiada do modo como ele narra a própria história, diante da qual não há saída.

Veremos a seguir que ao longo de cada uma das histórias que se constroem ao redor dos castelos de cada personagem, neste romance, haverá algum tipo de reflexão sobre seus respectivos destinos. Esse ente, de fato, permeará toda obra, concentrando, em sua força, quase que um elo entre todos os eixos narrativos, que, apesar de parecerem independentes e autônomos, nos desdobramentos das histórias, acabarão nas mãos do grande, inevitável e fatal jogador: o Destino, aquele que dá o xeque mate, nas marcas deste grande tabuleiro.

Teremos, por exemplo, o destino de Pehnt, que deverá partir, quando crescer tanto quanto o paletó que lhe deram para vestir, muito maior que ele, quando tinha ainda sete anos:

E così cresceva Pehnt. Mangiando uova a pranzo e cena, stando in piedi sulle seggiole, e annotando una vertità al giorno su un 
quaderno viola. Girava con quella enorme giacca addosso come viaggia una lettera nella busta che reca scritta la sua destinazione. Girava avviluppato nel suo destino. (BARICCO, 1999, p. 50)

Num dos capítulos que se referem a Hector Horeau, encontraremos: "Il destino dà appuntamenti strani” (BARICCO, 1999, p.142). E o narrador nos contará como, após um sério desmaio (fruto de uma espécie de convulsão de que sofria o gênio que viria a construir o Palácio de Vidro), ele acabará, por força do destino, se casando com Monique Bray, que, por sua vez, respectivamente, por conta de seu próprio destino, se atirará debaixo dos trilhos de um trem que não teria tempo de frear. Tudo porque: "la vita è sostanzialmente incoerente e la previdibilità dei fatti un'illusoria consolazione.” (BARICCO, 1999, p.147)

De modo análogo, haverá um verdadeiro elenco de como será o destino de cada um dos habitantes de Quinninpak, que tocarão na apresentação da banda de Pekisch. Nesse episódio, o narrador parece desfocar a lente da câmera que, naquele momento os apresenta vivos, tocando, lado a lado, para um súbito futuro que poderia se resumir em: vejam como cada um deles terminará sua trajetória. Com este tipo de procedimento de antecipar, como que premonitoriamente o que lhes acontecerá, o narrador salta do momento presente a um futuro certo, determinado e implacável, como se quisesse reiterar a assertiva primeira e única, a de que haverá sempre um destino que "marca estranhos encontros"33

Muito significativa, também, é a passagem em que o sr. Rail reflete sobre o destino de Jun. Quando ele a vê e se apaixona por ela, consegue dissuadi-la da idéia de partir, contando-lhe as infinitas histórias que a levariam a viver com ele em Quinnipak. Porém, desde o início, ele sabia que, em algum momento, Jun deveria retomar aquele sonho de partir, num navio, para algum lugar distante. Era como se, por sua interferência, o destino de Jun, tivesse apenas e somente aberto um parênteses, no corpo de início, meio e fim de sua trajetória. A ida de Jun a Quinnipak, para seguir o sr. Rail duraria enquanto durassem as suas histórias. E, de fato, é o que se revelará, ao fim. Jun partirá, dentro do primeiro plano ficcional, como a personagem esposa do homem dos trens, a que recebe as caixas, com as supostas jóias, que, na verdade, são as histórias. Por isso mesmo, no momento em que decide partir, carrega apenas um livro.

\footnotetext{
${ }^{33}$ Esse trecho, bastante elucidativo, encontra-se à p. 170 de Castelli di rabbia .
} 
No último capítulo, que já examinamos mais detalhadamente ${ }^{34}$, neste segundo plano ficcional, a narradora já se encontra no navio que a levará para a América e decide partir, por não mais suportar viver uma vida difícil e insustentável. Mas o que é surpreendente é a revelação de que escreverá, pois enquanto escrever para a menina Elena, como prometera, estará, de certo modo, se salvando e existindo.

Vejamos, apenas a título ilustrativo, como se refere ao destino de Jun, o sr.Rail:

(...) Ma non riuscirò per sempre a tenerla qui, gliel'ho promesso, un giorno lei si alzerà, prenderà quel suo maledettissimo libro e se ne tornerà a Morivar: e io la lascerò andare. (...) Prima di me c'è arrivato quel libro, nella sua vita, e io non ci posso fare niente. Sta lì, a metà strada, quel maledetto libro, e non potrà stare lì per sempre. Un giorno ripiglierà il suo viaggio. E Jun è quel viaggio. Lo capisci? Tutto il resto, Quinnipak, questa casa, il vetro, tu, Mormy e perfino io, tutto il resto non è che una grande fermata imprevista. Miracolosamente, da anni, il suo destino trattiene il fiato. Ma un giorno tornerà a respirare. E lei se ne andrà.(...) forse Jun è così bella perchè ha addosso il suo destino limpido e semplice... (BARICCO, 1999, p.212-213)

Do mesmo modo como, diversas vezes, encontramos referências à onipotência do destino, também, perceberemos algumas assertivas sobre os sentidos da vida que podem remeter às máximas, as quais carregam, implicitamente, algum tipo de conselho.

Assim, vale a pena analisar o conselho do velho Andersson ao sr. Rail, pouco antes de morrer. Este velho é um artesão que entende tudo sobre vidros. A sabedoria, aqui, é explicitamente elogiada e está relacionada ao conhecimento adquirido pela experiência daquele que faz, que trabalha manualmente o vidro, tal como o lapidador trabalha a pedra.

Andersson, na verdade, representa a alma da vidraçaria Rail, o que detêm, entre todos, uma espécie de sabedoria ancestral, conferida pela idade (é o mais velho de todos) e pela experiência de artesão. É a figura mais respeitada pelo sr. Rail e por todos os demais trabalhadores do local. Seu conselho resume-se em revelar que, na verdade, na vida devemos aceitar principalmente, o erro, o que nem sempre tem bom êxito. Fazendo uma analogia às bolhas de cristal (das quais ele era um expert) conclui que, tal como ocorre com

\footnotetext{
${ }^{34}$ Ver p. deste estudo
} 
elas, mais cedo ou mais tarde, em algum momento, acabarão se rompendo. E, diante dos desvios, do imprevisível, daquilo que poderia ser considerado "erro", seu conselho é o de não levar em consideração os comentários alheios, já que "todas as bolas de cristal que terá quebrado eram apenas vida... não são erros... é a vida... e a vida verdadeira é exatamente aquela que se quebra, aquela vida, em cem, que finalmente se quebra... eu compreendi isto..." (BARICCO, 1999, p. 124, trad. nossa)

A partir do que foi exposto, temos o conselho, partindo da experiência (algo compreendido, primeiramente, a partir da vivência de quem aconselha) para ser comungado com o ouvinte, receptor dessa espécie de sabedoria, colhida no campo fecundo da própria vida.

Essa máxima concedida a Andersson, de certo modo, sintetiza a dinâmica maior dos movimentos de ascensão e queda que norteiam toda obra e abrem um espaço privilegiado ao imperfeito, como a outra face da moeda que é preciso saber incorporar, como os elementos apoéticos que o poeta moderno tenta traduzir como fonte de suas apreensões estéticas.

O velho sábio revela a Rail a necessidade da compreensão do impreciso, do imprevisível, do impermanente como categorias constituintes desse espírito moderno, eminentemente contraditório, que, por se apresentar assim, é belo.

Teremos, também, quando Mormy vê Jun pela primeira vez, uma descrição muito poética, que busca traduzir aquele modo peculiar com que esse menino apreende a realidade à sua volta. Mormy é o personagem, tal como outros representativos, nas demais obras de Baricco, caracterizado pela "ombra d'oro" ${ }^{35}$. Pertenceria, então, a uma categoria de seres especiais que, por uma excessiva sensibilidade e principalmente por verem as coisas, as pessoas, o ambiente de um outro modo, teriam dificuldades de se adaptar ao mundo e ao sistema tal como posto.

Encontrar-se-iam na mesma instância de Mormy, talvez, Novecento (NV), a menina Elisewin (OM), o prof.Bartleboom (OM) e Ultimo Parri (Questa Storia).

No trecho que se refere a Mormy, a voz desse narrador parece traduzir o modo como algumas impressões permanecem na memória, carregadas de significado que poderão

\footnotetext{
${ }^{35}$ Essa expressão é a que define o personagem Ultimo Parri, logo às primeiras páginas do romance Questa Storia,
} 
surgir, de repente, ao longo de toda vida, por meio de qualquer índice ou sinal que as evoque. Assim, aquilo que impregnou, certa feita, nosso espírito, poderia ser, repentinamente, revivido, por exemplo, por um cheiro, uma simples imagem ou uma cor. Quase proustianamente, a memória, em particular a desses seres especiais como Mormy, seria constituída, sobretudo, pelas inter-relações sinestésicas que levam à exacerbação dos sentidos que passam a se corresponder. ${ }^{36}$

Dessa forma, Mormy como que absorverá inteira e intensamente aquele primeiro momento, em que entra na sala de jantar da casa dos Rail e em que o vulto de Jun, de tão belo, o perturbará:

Tutte queste cose e il volto de Jun. Gli erano entrate negli occhi, quelle due immagini, come l'istantanea percezione di una felicità assoluta e incondizionata. Se le sarebbe portate dietro per sempre. Perché è così che ti frega la vita. Ti piglia quando hai ancora l'anima addormentata e ti semina dentro un'immagine, o un odore, o un suono che poi non te lo togli più. E quella lì era la felicità. Lo scoprì dopo, quand'è troppo tardi, E già sei, per sempre, un esule: a migliaia di chilometri da quell'immagine, da quel suono, da quell'odore. Alla deriva. (BARICCO, 1999, p.26)

O tom mais reflexivo desse narrador, que se dirige, diretamente ao leitor, parece querer revelar mais um segredo da arte de viver, mais uma máxima de vida, capaz de traduzir as sensações que, naquele preciso momento, impregnam o espírito de Mormy.

As diversas situações que buscamos analisar, observando como os diferentes discursos desses múltiplos narradores se manifestam, nos sinalizam mais uma das estratégias de Baricco em sua arte de narrar. Seja na representação mais gratuita e espontânea dos dizeres que a viúva Abegg recupera em "Come diceva mio caro Charlus", seja nas máximas de vida mais elaboradas e menos empíricas, que poderiam se situar na mesma categoria dos aforismos, o autor coloca no centro do palco, o conselho. E é preciso notar que, assim procedendo, atualiza a teoria de W. Benjamin.

Além disso, quando concede às diferentes vozes narrativas, um modo de dizer as tais máximas, com um acento e um tom muito peculiar, exacerba as diferenças, as

\footnotetext{
${ }^{36}$ A respeito da memória sinestésica, há um interessante estudo feito por Fredric Jameson em As marcas do visível. Rio de Janeiro: Graal, 1995, p.1-6.
} 
individualidades, as percepções e visões de mundo de cada um. Ao mesmo tempo, sem distinguir hierarquicamente as sentenças mais elaboradas e eruditas das demais, espontâneas, empíricas, populares, justapondo-as e fazendo-as conviver ${ }^{37}$, reforça a idéia de que a verdadeira sabedoria é a que se colhe, a partir da experiência vivida, independentemente do registro ou da classe social à qual pertença o falante.

Concluindo, haveria que se lembrar uma das mais importantes dessas "verdades", a que será dita, logo na sequiência do diálogo entre os meninos de Quinnipak e o sr. Rail, quando lhe perguntam se Mormy seria louco. Neste momento, a voz do narrador refletirá sobre o próprio narrador e sobre a arte de narrar, assumindo, explicitamente, um procedimento metaliterário, em que o texto ficcional abre um espaço de auto-referência, revelando um espelho que parece refletir a si mesmo, tocando, assim, em sua própria alma. Será, de fato, o grande achado desta obra, quanto à função de narrar, quanto aos significados que podem ser extraídos, a partir destas constatações.

Em síntese, a partir do que, neste episódio se conta como verdade, como crença foi-nos possível estabelecer uma série de premissas que passaram a nortear esta pesquisa: a necessidade de descobrir o velho narrador que habita em cada um. Este narrador que resiste nos conta uma história infinita e rica em mil detalhes. Ele é quem nos conta a vida e mora dentro de nós. E, assim sendo, enquanto tivermos condições de ouvi-lo, estaremos salvos e voltaremos a trocar experiências, resgatando a força da palavra que, em tempos de guerra e violência nos fora roubada. Daí porque é fundamental voltar a narrar. Narrar é resistir. Narrar é viver. ${ }^{38}$

\footnotetext{
${ }^{37}$ A força narrativa da viúva Abegg, mais espontânea e empírica se equipara à força narrativa mais elaborada e aforística do sr. Rail, por exemplo.

${ }^{38}$ Esse precioso trecho, que já foi referido nesta pesquisa, se encontra às p. 116-117 de Castelli di rabbia.
} 


\section{CONCLUSÃO}

Procuramos, neste estudo, analisar duas obras do escritor italiano contemporâneo Alessandro Baricco: Novecento (1994) e Castelli di rabbia (1991).

Numa perspectiva mais ampla, pretendemos incluir, em futura análise, Oceano mare (1993).

De fato, é interessante notar que, cada uma dessas obras, nos remeteu a importantes eixos de reflexão, que acabaram por nos induzir às três categorias que Ezra Pound criou, em sua revolucionária teoria sobre tradução de poesia. Nesta teorização, ele esclarece que a poesia é constituída, basicamente, de três elementos: a melopéia que trata da musicalidade e do som das palavras; a fanopéia que traduz a projeção de imagens e a logopéia que seria o uso especial, o jogo que as palavras assumem no poema. Esses três elementos, segundo o poeta, convivem no âmbito da tessitura do poema. (POUND, 1970)

Analogamente, poderíamos tomar essas três instâncias emprestadas a Pound para melhor organizar nossas idéias. Para tanto, partimos da pressuposição de que lidamos, essencialmente, com textos de prosa poética (conforme pudemos constatar, ao longo do desenvolvimento desta pesquisa).

Assim, trabalhamos, num primeiro momento com a música (é por meio de sua arte, da música que Novecento encontrou a verdadeira liberdade); em seguida, com o logos, a palavra, as histórias tanto contadas, quanto ouvidas, tanto ditas quanto escritas, pois encontrar "o velho narrador que habita em cada um de nós e que nos conta a vida" é, também, um modo de libertação na sociedade dos condicionamentos. E num terceiro plano, Oceano mare, que no limite, remete à imagem, pois abre a uma série de indagações sobre a problemática do olhar, da urgência de reeducá-lo, em tempos dominados pela cegueira generalizada (tão bem tratada por José Saramago, entre tantos outros) ${ }^{39}$.

Nos três casos, verificamos que o que pode conduzir à uma acepção plena de liberdade (tema tratado no $1^{\circ}$ capítulo) acaba sendo, inevitavelmente, a arte e a capacidade

\footnotetext{
${ }^{39}$ A propósito ver o $1^{\circ}$ capítulo desta pesquisa.
} 
humana de saber narrar, pois contando, ouvindo e escrevendo histórias, o ciclo da troca de experiências se reabilita e o homem pode encontrar novas formas de humanização.

Portanto, recuperando a voz (em Castelli di rabbia), alargando as possibilidades de ver o mundo (em Oceano mare), estaremos, por meio da arte (em Novecento) buscando algum tipo de resistência.

Em entrevista a Cinzia Fiori: "Ballando con i sogni nei Castelli di Baricco" publicada no Corriere della Sera, em 2003, Alessandro Baricco se assume como sendo um narrador, que diz ver e conviver com histórias o tempo todo. Pertence a um grupo de escritores e artistas que acredita ser possível resistir aos apelos de toda ordem, propostos pela sociedade contemporânea, por meio da reinvenção da arte de narrar. E acredita nisso como um dever natural:

Io sono un narratore, ho quel talento lì - dirà a fine intervista vedo storie anche in questo tavolo, mi parla. Ho lavorato molto per dire che viviamo in mezzo alle storie e che bisogna raccontarle bene, con rispetto. È un compito civile, come quello del panettiere qua sotto. Io ho bisogno di lui e lui di me. Gli uomini hanno bisgono di storie. Non soltanto per trasmettere sapere. Ogni storia è la custodia della speranza che questa vita non sia l'unica, che se uno volesse potrebbe avere un'esistenza differente. (BARICCO, 2003)

Cumpre ressaltar, ainda mais uma vez, que essa postura de revitalização do narrador não assume, em Baricco, a dimensão nostálgica do que se perdeu. Melhor dizendo, o fato de se apoiar nas teorias de W. Benjamin, sobretudo no texto que analisamos ${ }^{40}$, parece apenas trazer à luz as questões que demonstram as possíveis causas e consequiências da morte do narrador, para, a partir delas, propor novas possibilidades de narrar.

A imagem do pensador, intelectual, ensaísta, educador, ficcionista, enfim desse ser multimidiático que é Alessandro Baricco tem feito com que ele apareça no cenário internacional, segundo alguns, de modo um tanto quanto "contraditório" e "espetaculoso".

Gostaríamos, apenas de citar, como exemplo disso, uma certa polêmica gerada, a partir da publicação recente de "Sul banco dei cattivi - a proposito di Baricco e di altri

\footnotetext{
${ }^{40} \mathrm{O}$ texto a que nos referimos "O narrador" já foi referenciado anteriormente.
} 
scrittori alla moda" de autoria de Giulio Ferroni, Massimo Onofri, Filippo La Porta e Alfonso Berardinelli (2006).

Não é nosso intuito, aqui, tecer qualquer comentário sobre tão abalizada crítica. Porém, gostaríamos, apenas de sugerir algumas observações a respeito do primeiro ensaio: "Profondità di superficie" de Giulio Ferroni que abre o livro e se dedica, em particular a Alessandro Baricco.

O célebre crítico aponta, entre os inúmeros problemas do autor, o fato de que, em sua obra, haveria uma supervalorização de histórias, de todo tipo e gênero que poderiam conduzir ao exagero desnecessário, a ponto, até mesmo, de tê-lo feito dar um título como "Questa storia" para seu último romance:

Bella cosa è certo sentirsi raccontare "storie", ma fastidiosa davvero (e diffusissimo ahimé non solo in Baricco, ma in molti scrittori odierni più o meno giovani) è l'identificazione dell'esistenza con le storie stesse, l'insistenza sulla necessità di raccontare "storie", tanto più che infinite sono le storie, storiette, storiacce, che la comunicazione attuale ci propina da tutte le parti. Quante storie insomma!fino ad arrivare al punto di intitolare un romanzo, dimostrativamente, indicativamente, Questa storia, con un titolo che si pone come un richiamo pubblicitario ridotto all'essenza, alla pura struttura, al suo guscio vuoto. (FERRONI, 2006)

Sem pretendermos entrar no mérito da questão, apenas precisamos notar que o apelo com que Baricco "convoca" o leitor às suas "infinitas histórias" não parece ser injustificado. Ao contrário, diante do estudo que buscamos desenvolver, ao longo destas páginas, essa necessidade de "histórias" se faz urgente, devido a uma série de causas inseridas no contexto sócio-histórico-político em que vivemos e do qual procuramos tratar aqui. Nesse sentido, não vemos como um defeito essa "insistência" nos modos de contar histórias, porque sabemos que ela, nada mais é do que uma espécie de reação contra a violência de sociedades que se organizam, extirpando do humano toda e qualquer possibilidade de expressão. 
Além disso, o último romance "Questa storia", segundo nossa análise, pode ser excelente ponto de partida para uma postura de revisão da História oficial, já que trabalha com a hipótese de que "a História é uma ilusão de ótica" ${ }^{41}$ (trad. nossa)

Guardando as devidas medidas e proporções, um dos riscos que se pode correr na compreensão crítica de qualquer autor é deixar de lado o valor da obra em si. A esse respeito, vale lembrar o interessante estudo de Milan Kundera (já referenciado nas páginas desta nossa pesquisa) sobre os "desvios" sofridos pela obra de Kafka, a partir das leituras e projeções feitas por Max Brod. É verdade, diz ele, que sem Brod, talvez, nem soubéssemos o nome de Kafka. Porém, Brod criou a imagem de Kafka e a de sua obra: criou a "kafkologia" que acaba examinando os livros do autor fora do grande contexto da história literária, desalojando-o sistematicamente do domínio da Estética. (KUNDERA, 1993, p.3539).

Analogamente, gostaríamos, para concluir nossa análise, de lembrar que seria injusto tratar da imensa obra de Alessandro Baricco, esquecendo sua importância como autor esteticamente comprometido com seu tempo, que pertence a uma linhagem de pensadores que atravessam a fronteira do verossímil, não para "evadir-se do mundo real", mas para melhor apreendê-lo. Um autor que tem consciência de um fazer literário aberto a inesgotáveis diálogos intertextuais com autores e obras das mais diversas épocas e culturas.

Em Castelli di rabbia, por exemplo, tocamos inevitavelmente nas "Elegias de Duíno" de Rilke, nos castelos de "Orlando, o furioso" de Ariosto, além das questões centrais da Modernidade. Em Novecento, a partir da relativização do conceito de liberdade, propusemos o diálogo com o conto "La libertà" de Dino Buzzati, além de tratar do minúsculo imenso universo do "Aleph" de J.L.Borges. Em Oceano mare (assim como, também já anunciado em Novecento), o foco se direciona em torno da problemática do olhar, remetendo a autores como José Saramago, Italo Calvino, João Guimarães Rosa, além da intertextualidade explícita com Joseph Conrad e Herman Melville.

Talvez, como Patrick Chamoiseau ${ }^{42}$ (1994) que destaca os principais traços da cultura na Martinica, principalmente das pessoas que fazem a história (com h minúsculo) ao

\footnotetext{
${ }^{41}$ Esta frase é dita por Elizavetta à p.154 do romance Questa storia.

${ }^{42}$ Patrick Chamoiseau acredita que a cultura das Antilhas foi construída com base na oralidade e portanto faz uso dessa característica constantemente em suas obras, onde se encontra a presença de diálogos e outros termos em "crioulo". Sua obra tenta "traduzir" essa cultura para que possa ser conhecida pelo resto do mundo.
} 
invés de tomar como ponto de vista os grandes personagens da História (com h maiúsculo), as insistentes histórias de Alessandro Baricco possam nos retirar da presença onipotente e, muitas vezes, tirânica, dos detentores da História. Talvez, elas tenham a força de nos jogar num imenso oceano mar, do qual, nossa única certeza é a de que sairemos banhados de vida... 


\section{REFERÊNCIAS BIBLIOGRÁFICAS:}

ABBAgnano, N. Dicionário de Filosofia. Trad: Alfredo Bosi e Ivone Castilho Benedetti. São Paulo: Martins Fontes, 2003, p.605- 612.

ADORNO, T. Indústria cultural e sociedade. São Paulo, Paz e terra, 1993.

ADORNO, T. In: Letche, J. 50 pensadores contemporâneos essenciais. Do estruturalismo à Pós-Modernidade. Rio de Janeiro: Bertrand Brasil Ltda., 2002, p.200.

ADORNO, T. \& BENJAMIN,W. \& HABERMAS, J. \& HORKHEIMER, M. Os pensadores. São Paulo: Abril Cultural, 1980, p. XVI e XVII.

ALIGHIERI, D. A divina comédia. Inferno-CantoV-4. Trad. e notas: Italo Eugenio Mauro. São Paulo: Ed.34, 2004, p.49.

ALIGHIERI, D. A divina comédia. Purgatorio - Canto I. Trad. e notas: Italo Eugenio Mauro. São Paulo: Ed.34, 2004, p.13-18.

BARICCO, A. Andata e ritorno: destinazione l'orrore - postfazione a CONRAD, J. Cuore di tenebre. Trad- Ettore Capriolo, Milano: Feltrinelli, p.113 a 121.

BARICCO, A. \& TARASCO, R. \& VACIS, G. Balene e sogni- Leggere e ascoltareL'esperienza di Totem. Torino: Einaudi, 2003. p.5.

BARICCO, A. Barnum - Cronache dal Grande Show, Milano: Feltrinelli, 2004.

BARICCO, A. Castelli di rabbia. Milano:BUR- La scala, 1999, p.116.

BARICCO, A. Entrevista com Alessandro Baricco in MARTIRANI, Maria Célia. À procura do velho narrador que habita em cada um de nós.Curitiba:Travessa dos editores, nov-2006, v.9, p.186 a 193.

BARICCO, A. Leggendo Benjamin al Teatro Palladium di Roma.Roma, teatro Palladium, 16, 17 e 18 de janeiro 2004 In:

http://www.oceanomare.com/news/archivio/benjaminpalladium.htm

BARICCO, A. Novecento: un monologo, Milano : Feltrinelli, 2002, p. 17.

BARICCO, A. Mundos de vidro. Título original: Castelli di rabbia. Trad: Elia Ferreira Edel, Rio de Janeiro: Rocco, 1999.

BARICCO, A. Oceano mar. Título original: Oceano mare. Trad: Roberta Barni. São Paulo: Iluminuras, 1997, p.22.

BARICCO, A. Oceano mare.Milano:Rizzolli, 1999. 
BARICCO, A. Questa storia. Roma: Fandango Libri, 2005, p.154.

BARTHES, R. Análise estrutural da narrativa. 2 ed. Petrópolis:Vozes, 1972.

BENJAMIN,W. Angelus novus: saggi e frammenti. Torino: Einaudi, 1962. p.247 a 274.

BENJAMIN, W. O narrador: observações sobre a obra de Nikolai Leskow. Trad: Modesto Carone. In: Os pensadores. São Paulo: Abril Cultural, 1980, p.57.

BERARDINELLI, A.: Não incentivem o romance. São Paulo: Humanitas, 2007, p.95.

BERKELEY, G. in Ilusionismos de CORTELLA, M. S. In:Folha de São Paulo, 10 de junho de 2004 - Equilíbrio, p.12.

BERMANN, M. Tudo que é sólido desmancha no ar - A aventura da modernidade. Trad: Carlos Felipe Moisés e Ana Maria L.Ioriatti. São Paulo: Cia da Letras, 1995, p.13.

BORDELOIS, I. A palavra ameaçada. Trad: Alicia Ivanissevich. Rio de Janeiro: Vieira \& Lent casa editorial, 2005, p. 30.

BORGES, J. L. O aleph. Trad: Flávio José Cardozo. São Paulo: Ed. Globo S.A., 1989, p. 170-171.

BORNHEIM, G.A. As metamorfoses do olhar. In: NOVAES, A. (org.) O olhar. São Paulo: Cia das Letras, 2003, p.92.

BOSI, A. Fenomenologia do olhar. In: NOVAES, A.( org.) $O$ olhar. São Paulo: Cia das Letras, 2003, p.81.

BUZZATI, D. La libertà in In quel preciso momento. Milano: Mondadori, 1963.

CALVINO, I. I livelli della realtà in letteratura in Una pietra sopra, Milano:

Mondadori, 2002, p. 374.

CALVINO, I. I nostri antenati - nota 1960.In CALVINO, I. I nostri antenati: Il visconte dimezzato; Il barone rampante; Il cavaliere inesistente. Milano: Mondadori, 2005. p.413 - 422.

CALVINO, I. Le città invisibili. Milano: Mondadori, 1999

CALVINO, I. Lezioni americane. Milano: Mondadori, 1990.

CALVINO, I. Mondo scritto e mondo non scritto.Milano: Mondadori, 2002.

CALVINO, I. Orlando Furioso di Ludovico Ariosto - raccontato da Italo Calvino. Milano: Mondadori, 2002, p.172. 
CALVINO, I. Palomar Milano:Mondadori, 2006.

CALVINO, I. Sulla fiaba.Torino: Einaudi, 1988.

CHAMOISEAU, P. \& RENAUDEAU, V. Martinique. Ensaio, Paris: Gallimard, 1994.

CANETTI, E. O ofício do poeta (discurso proferido em Munique, em 1976). In: A consciência das palavras. Trad: Herbert Caro, Marcio Suzuki. São Paulo: Cia das Letras, 1990.

CARVALHO, B. A realidade replicante, In: Folha de São Paulo, São Paulo, 2 de setembro de 2003.

CARVALHO, W \& JARDIM, J. Janela da alma - documentário vencedor do Grande Prêmio Cinema Brasil-2001.

CONRAD, J. A loucura do Almayer. Trad: Julieta Cupertino, Rio de janeiro: Revan, 1999.

DÄLLENBACH, L. Intertexte et autotexte, Poétique (27) (1976); Id: Le récit spéculaire. Essair sur la mise en abyme, 1977.In:

http://www.fcsh.unl.pt/edtl/verbetes/M/mise_en_abime.htm

DEBORD, G. A sociedade do espetáculo. Trad: Estela dos Santos Abreu. Rio de Janeiro: Contraponto, 2007.

FUENTES, C. Geografia do romance. Trad: Carlos Nougué. Rio de janeiro: Rocco, 2007, p.19.

FERRONI, G. \& ONOFRI, M \& LA PORTA, F. BERARDINELLI, A. Sul banco dei cattivi - A proposito di Baricco e di altri scrittori alla moda. Roma: Donzelli Editore, 2006.

HABERMAS, J. O caos da esfera pública in Suplemento Mais - São Paulo: Folha de São Paulo-13- agosto 2006- p. 4 e 5.

HÖLDERLIN, F. Reflexões seguidas de Hölderlin, Tragédia e Modernidade, por DASTUR, F. Trad:Marcia C. de Sá Cavalcanti e Antonio Abranches, Rio de Janeiro: Relume-Dumará, 1994.

HUIZINGA, J. Homo ludens. São Paulo: Perspectiva, 2004.

JOBIM E SOUZA, S. Leitura entre o mágico e o profano: os caminhos cruzados de Bakhtin, Benjamin e Calvino. In: FARACCO, C. A/ TEZZA, C./ DE CASTRO, G. (orgs.) Diálogos com Bakhtin. Curitiba: Editora UFPR, 1996. p.189-206. 
KAPUSCINSKI, R. in CARVALHO, B. Cruzar a fronteira. São Paulo: Folha de São Paulo, Ilustrada, 27-02-2007.

KUNDERA, M. in MAFFEI, M., sel. Os escritores: as histórias entrevistas da Paris Review. Trad. De Alberto Martins e Beth Vieira. São Paulo: Cia. das Letras, 1988. p.315-27.

KUNDERA, M. Os testamentos traídos. Trad: Teresa Bulhões Carvalho da Fonseca e maria Luiza Newlands Silveira do original francês, 1993.

KURZ, R. A ignorância da sociedade do conhecimento, Trad: Marcelo Rondinelli, São Paulo: Folha de São Paulo, Caderno Mais, 13-jan-2002.

LEXICON, H. Dicionário de símbolos. São Paulo: Cultrix, 1990, p.183.

LIPOVETSKY, G. \& CHARLES, S. Os tempos hipermodernos. Trad. Mário Vilela. São Paulo: Barcarolla, 2004.

LOURENÇO, E. Do trágico e da tragédia. In: O canto do signo- Existência e literatura. Lisboa: Presença, 1994.

MERLEAU-PONTY, M. O visível e o invisível. São Paulo: Perspectivas/Dinalivro, 2002.

MERLEAU-PONTY, M. Fenomenologia da percepção. São Paulo: Martins Fontes, $1999,2^{a}$ ed.

PEIXOTO, N.B. O olhar do estrangeiro. In: NOVAES, A. (org.) O olhar. São Paulo: Cia das Letras, 2003, p.361.

PESSOA, F. Livro do desassossego. São Paulo: Cia. das Letras, 1999.

POUND, E. ABC da literatura. Trad: Augusto de Campos e José Paulo Paes. São Paulo: Cultrix, 1980, p.11.

RILKE, Rainer Maria. Elegias de Duíno.Trad e comentários: Dora Ferreira da Silva, São Paulo: Ed. Globo, 2001.

ROUANET, S. P. O olhar iluminista. In: NOVAES, A. (org.) O olhar. São Paulo: Cia das Letras, 2003., p.125 a 148.

SARAMAGO, J. Ensaio sobre a cegueira, São Paulo: Cia das Letras, 1995.

SARTRE, J. P. Qu'est-ce que la littérature?, Paris: Gallimard, 1967.

SAVATER, Fernando. Etica per un figlio, Bari: Laterza, 1992. 
SCHILLER, F. Cartas sobre a educação estética da humanidade. Trad. R. Schwarz. São Paulo: Herder,1963.

SEGALEN, V. Ensaio sobre o exotismo. In: CARVALHO, B. Cruzar a fronteira. São Paulo: Folha de São Paulo, Ilustrada, 27-02-2007.

SONTAG, S. Questão de ênfase. Trad: Rubens Figueiredo. São Paulo: Cia das Letras, 2005, p.96-97.

TELES,G.M. Vanguarda européia e modernismo brasileiro. Rio de Janeiro: Vozes, 1978, p.83, 85-86.

VARGAS LLOSA, M. È pensabile il mondo moderno senza il romanzo? In:

MORETTI, F. Il romanzo. Torino: Einaudi, 2001, p.3-15

VELOSO, C. Cajuína, com citação de poema de Sapho, Rio de Janeiro: Gapa, 1979. 


\title{
ANEXO
}

\section{ÍNTEGRA da matéria "Entrevista com Alessandro Baricco: à procura do velho narrador que habita em cada um de nós", na Revista de Literatura e Arte Etcetera número 9, Curitiba: Travessa dos Editores, 2006, p.188-193}

\author{
por: Maria Célia Martirani
}

Alessandro Baricco, autor italiano contemporâneo, foi um dos convidados especiais do Boca do Céu- II Encontro Internacional de Contadores de Histórias, promovido pelo SESC- Pinheiros, em São Paulo de 12 a 21 de maio. Além da vasta obra ficcional, é autor de ensaios, críticas, roteiros e textos teatrais, colaborando com artigos para vários jornais europeus, em especial para o La Reppublica. Intelectual ativo, criou vários projetos e programas para televisão. Entre estes, destaca-se o interessantíssimo Totem, cuja idéia central é a de ler contos, trechos extraídos de obras literárias diversas, em voz alta, em grupo. Criou, em Torino, a escola de narrativa, Holden.

O monólogo Novecento, escrito, a princípio, para teatro, deu origem ao filme, dirigido por Giuseppe Tornatore: A lenda do pianista do mar (La leggenda del pianista sull'oceano- 1998). Seu último romance, Questa storia, lançado pela Fandango-Libri de Roma, em novembro de 2005, deverá, também, em breve, ser adaptado para o cinema.

Do que pudemos aprender, no prazeroso encontro que, com ele, tivemos, percebemos que se trata de um escritor- artesão da narrativa. Acredita na arte de narrar como forma de resgatar o que, de humano, ainda nos resta, numa sociedade que reifica tudo e todos e vai, a cada dia, nos alienando, neste universo saturado de imagens e informações, que dizem tudo, sem dizer, em essência, nada. De fato, seguindo várias das proposições do filósofo Walter Benjamin, sobretudo as que estão no texto $O$ narrador-Considerações sobre a obra de Nikolai Leskov ${ }^{43}$, com o qual fez questão de trabalhar, durante os três dias de sua oficina no Sesc Pinheiros-SP, ele parece querer recuperar a força e o vigor das narrativas ancestrais, capazes de restituir os traços sensíveis de nossa humanidade entorpecida. Essa tentativa de reinventar o contador de histórias, ao redor do calor do fogo, que aquece os frios de nossa existência, não se reflete, em Baricco, como uma postura nostálgica ou apocalíptica, de simples lamento e total desesperança, em

\footnotetext{
${ }^{43}$ BENJAMIN, W. O narrador:observações sobre a obra de Nikolai Leskow. trad: Modesto Carone. In: Os pensadores. São Paulo: Abril Cultural, 1980, p.57.
} 
relação ao que se perdeu. O que, de fato, surpreende é a sua capacidade de atualizar, ficcionalmente, como uma espécie de discípulo benjaminiano, a antiga lição do grande filósofo: narrar é dar voz e vida, ao que foi obrigado a emudecer.

Diante da desintegração da experiência, já que não há mais tempo, nem espaço para histórias que sejam contadas, nem pessoas que queiram ouvi-las, é urgente reencontrar o narrador. Daí, porque em seu primeiro romance, Castelli di rabbia, no amplo leque de vozes narrativas que se abrem, há a seguinte constatação:

A verdade é que se vêem, se sentem e se tocam assim tantas coisas... é como se trouxéssemos dentro de nós um velho narrador que o tempo todo continua a nos contar uma história rica em mil detalhes e que jamais termina. Ele conta, não desiste nunca e isso é a vida... Há alguns que o chamam de "anjo", o narrador que trazem dentro de si e que lhes conta a vida. ${ }^{44}$

Narrar, portanto é, mais que tudo, um ato de resistência. Narrar é restituir a vida que, de uma ou outra forma, nos vai sendo, quotidianamente, negada. E, enquanto estivermos atentos ao que nosso velho narrador, aquele que habita em cada um, nos conta, então, estaremos salvos e tal como Sherazade, nos livraremos da morte. É, também, o que o famoso personagem Novecento, pianista que viveu toda uma vida dentro de um navio, sem jamais sair dos limites da proa a popa, nos ensina:

Você nunca se dará mal, desde que tenha uma boa história e alguém a quem contá-la. ${ }^{45}$

Assim, percorrer o universo ficcional de Alessandro Baricco é redescobrir o prazer de ler, como se estivéssemos ouvindo histórias, que levam a outras que, por sua vez, vão se abrindo em outras, tantas, infinitas, a fim de que queiramos permanecer na viagem, sem a menor pressa de chegar.

Ao final do terceiro dia de nosso riquíssimo encontro, pouco antes de se despedir para tomar o avião que o levaria de volta à Itália, ele nos contou uma história. Disse-nos, emocionado, que seu filho, quando ainda bem pequeno, entre as primeiras palavras que ia aprendendo a balbuciar, sempre enunciava: "aua" (água) e "tóia" (história). Acrescentou que, especialmente, em momentos que poderiam representar-lhe alguma dor, como nas vezes em que tinha que tomar vacina, com os olhinhos lacrimejantes, pedia "tóia, tóia, tóia"... E nos fez, com isso, compreender, aquilo que, no fundo, sabíamos, desde

\footnotetext{
${ }^{44}$ BARICCO, A. Casteli di rabbia, Milano: BUR-La scala, 1999, p.116. Trad. nossa.

${ }^{45}$ BARICCO, A. Novecento:un monologo, Milano:Feltrinelli, 2002, p.17. Trad. nossa.
} 
sempre: uma boa história é como um colo quente, tão necessária como a água que bebemos ou o ar que respiramos.

SESC- Pinheiros- 20- Maggio- 2006:

1) In Novecento, ci sembra che, nonostante dentro i confini, "dalla prua alla popa" della nave, quel pianista fosse molto più libero di noi che viviamo in questa "vera prigione a cielo aperto" (come dice Adorno). Cos'è, per Novecento, la vera libertà?

R: Quello sì, per Novecento, è la libertà. La libertà, per Novecento, è potere scoprire tutto quello che sei in grado di scoprire all'interno di un confine. Questo è essere libero. Se il confine non c'è, lui dice, sei Dio. Ma è una situazione che, per gli umani, è insostenibile, è troppo angosciante. Questo è proprio quello che pensa lui.

1) Hölderlin concepiva la musica come simbolo della genesi del mondo. Si sà che, nella celebre torre di Tübingen, per più di trent'anni di una specie di "imbrunire" della mente, lui passò il tempo cantando. E, forse, si possa dire che lui l'ha fatto, perchè la genesi di un mondo è, essenzialmente, un fenomeno di risonanza.

Non sarebbe qualcosa simile a quello che credeva il personaggio Pekisch di Castelli di Rabbia, creando "l'umanofono", una specie di tastiera umana, in cui i tasti erano gli uomini e le loro voci?

R: Fammi pensare... Lui è un uomo che vive nell'universo musicale. All'interno di quell'universo, lui cerca l'origine, cioè, un punto, uno solo dove ci sia il senso di tutto; allora c'è l'umanofono.

Però, l'altro lo cerca nei vetri; l'altro, ancora, nei treni. Se lui, Pekish cerca quel punto originario, cerca il punto in cui il senso è completamente raccolto nel suo universo, che è l'universo dei suoni.

2) Potresti definire che cos'è, per te, la Letteratura? Com'è il tuo rapporto con l'atto di scrivere? Il tuo mestiere di scrittore ti fa venir fuori "il sugo dal gomito"?

R: Diciamo che è come un lavoro artigianale molto faticoso, però mi è molto congeniale; quindi, è una fatica che sopporto molto bene e non è una cosa che faccia tutti $i$ giorni, perchè non sono un abitudinario ed è una cosa, per me, molto emozionante: questa è la cosa che mi piace di più fare: scrivere. Pubblicare, invece, mi piace meno.

3) In Oceano Mare, il nome "Locanda Almayer" è una parodia, una specie di omaggio a Conrad, autore di La pazzia di Almayer?

R: Sì, ammiro moltissimo J. Conrad. Sí, è un omaggio. Ho scritto una postfazione per l'edizione italiana di Cuore di tenebra di Conrad, intitolata: Andata e ritorno, 
destinazione l'orrore ${ }^{46}$, in cui cerco di riflettere su quel suo, così detto, modo "imperfetto" di narrare. Io veramente credo che le opere di Conrad sono opere di confine. La loro imperfezione si tramuta in forza se si riconosce in essa il crepitare di un rito originario e mille volte più carismatico della letteratura: la narrazione.

4) Calvino afferma nelle Lezioni Americane che il "suo interesse per la fiaba è piuttosto un interesse stilistico e strutturale, per l'economia, il ritmo, la logica essenziale con cui sono raccontate". Cosa ne pensi di questo universo fiabesco?

R: A me, le fiabe non piacciono. Ho questo diffetto, io. Non amo le fiabe. Non mi interessano molto e quindi non mi è significato molto, neanche quando ero piccolo.

5) Secondo Kierkegaard "un sistema è un castelo di giganti, dove l'individuo non c'è posto." Novecento, Bartleboom, Mormy, Ultimo Parri, quelli che avevano "l'ombra d'oro" sono dovuti morire, perchè non si sarebbero mai adeguati al sistema?

R: Sì, in un certo modo sì. Però, ognuno di loro trova un modo per essere felice. Cioè, anche se apparentemente "inadattabili"al sistema, non sono persone infelici. Erano felici, nonostante il sistema. Erano più grandi del sistema. È Novecento chi dice:"Non siamo pazzi, quando troviamo un modo di salvarci."

6) In Castello di Rabbia, le epigrafe che aprono ogni capitolo sono di Rilke. Potresti commentare questa tua scelta?

R: Si tratta dell'Ottava Elegia Duinese di Rilke. Rilke mi piace molto! Secondo me, quelle epigrafi sono le epigrafi giuste a quel libro.

7) In Questa Storia, il primo diario che Elizaveta scrive rappresenta una "bugia". Come mai, un diario "bugiardo"?

R: Il diario di Elizaveta è falso, sì. Perchè può succedere che uno scriva un diario falso. C'è molta gente che lo fa, per esempio, quelli che, oggi, scrivono i blog. Per me, quello è solo un modo di raccontare...

8) In Oceano Mare, ce ne sono diversi bambini: Dood, Ditz, Dol, Dira, ecc... Sono come i bambini che vivono in ciascuno di noi? Quelli capaci di farci vedere quello che il nostro sguardo troppo condizionato non riesce a vedere più?

R: Non lo so... In un certo modo, tutti sono angeli.

10) Nelle tue opere, ci pare che tu cerchi, un po' come Benjamin, la precisione del movimento e, allo stesso tempo, l'eleganza della poesia. E ci sono alcuni, come il critico La Porta che ti definiscono come un post-moderno. Come ti definiresti? Saresti una specie di "scrittore benjaminiano post-moderno"?

\footnotetext{
${ }^{46}$ BARICCO, A. Andata e ritorno, destinazione l'orrore, in CONRAD, J. Cuore di tenebra. Milano: Feltrinelli, 2003.
} 
R: Benjaminiano, sì! Però, "post-moderno" è un modo semplicistico di capire le cose.

Secondo me, non c'è nessuno che capisca quello che faccio io, neanch'io.

11) Com'è il tuo rapporto co'l cinema?

$\mathrm{R}$ : É fortissimo. Infatti, i miei libri sono molto "cinematografici”. E ce ne sono quelli a cui non piacciono i miei libri, esattamente, per questo...

12) I giusti, secondo Benjamin, sono i veri "portavoci della creatura". Sono quelli che, come Bartleboom (di Oceano Mare) "non hanno la faccia da eroi, ma intanto tengono su la baracca." In diversi dei tuoi libri, appaiono personaggi di questo tipo. Potresti commentarli?

R: Secondo Benjamin, la narrazione proviene da due fonti:

a) dal mercante- quello che viaggia e che fa delle truffe

b) dal contadino- l'uomo onesto, ma che non esce dal paese

Noi ce ne abbiamo tutti due, il santo e il truffatore; il giusto(il contadino) e il mercante ( quello che ci induce a comprare); la madonna e la puttana. Se ci mancasse una di queste trace, l'arte di narrare non sarebbe completa. Se pensiamo ai narratori orali, loro hanno questi due tratti molto evidenti. E possiamo, anche dire, ancora con Benjamin che ce ne sono due tipi di narratoriscrittori:

a) quelli come Proust - il giusto

b) quelli come Melville, Conrad-il mercante, il viaggiatore

Logicamente ce ne sono molti ibridi, molti "vie di mezzo". Io mi considero come uno che si "agita" molto, quando scrive. Invece, per esempio Kafka è quasi immobile (lui ha fiducia nella forza delle sue parole).

Oggi, tutto è molto difficile. Sono pochi che hanno il profilo del contadino. Anche perchè la tecnica è diventata così alta e il pubblico dei libri è molto esigente...

I miei personaggi che simbolizzano "i giusti" forse rappresentino qualcosa con la quale mantengo una forte identità. Cioè, tra il mercante e il contadino, io sono più "contadino".

13) "Raccontare una storia", "Dire il mare", "Dare voce a quelli che tornano ammutoliti dalla guerra" sono cose che toccano allo scrittore?

R: Secondo me, sì, ma secondo altri, no. Sono, per me, i punti in cui ho cercato di spiegare la missione di uno scrittore.Logicamente, ce ne sono molti che non pensano come me.

14) Tu credi nel narratore come una sorta di artigiano. In termini letterari, come questo si concretizza? 
R: Bene, infatti, ho l'abitudine di chiedere ai miei alunni della Hölden (scherzzando, logicamente)che ricamino nei loro cuscini, quello che Valèry, ripreso da Benjamin, insegna sull'arte di narrare. Narrare, secondo lui, è lavorare come un artigiano, coniugando, allo stesso tempo, occhio, mano e anima, sulla materia della esperienza, in un modo utile, solido e irrepetibile. Ciò vuol dire che, per scrivere bene, dobbiamo, inanzitutto, fare attenzione allo sguardo degli artigiani. Percepire come loro guardano. Se qualcuno lascia di guardare con cura e dettagli, tutto diventa inutile.

Anche la mano è fondamentale nel lavoro di un artigiano. Ad uno scrittore questo sarebbe la tecnica ( con la mano, tutto diventa più fisico). Se pensiamo ad un falegname, per esempio, lui deve concentrare nelle mani, la precisione e il movimento necessari per rifilare il legno e togliere gli eccessi. Allora, occhio $e$ mano, a chi scrive, sono come la tecnica e lo sguardo minuzioso dell'artigiano. Però, nè l'occhio, nè la mano possono muoversi senza l'anima. E come definire l'anima? Forse, come quello che direbbe Louis Armstrong sul jazz. Se tu avrai bisogno di domandare cos'è il jazz, l'unica certezza sarà questa: non ci sarà mai una risposta alla tua domanda...

\section{5) Potresti commentare l'esperienza di Totem?}

R: Il primo capitolo del mio libro "Balene e sogni" in cui io e i miei colleghi cerchiamo di raccontare un po' il senso di Totem, contiene una citazione, tratta dall'opera di Calvino, "Le città invisibili". Marco Polo risponde a Kublai Kan, su quello che potrebbe essere l'Inferno: " L'inferno dei viventi non è qualcosa che sarà. ̇̀ quello che è già qui, l'inferno che abitiamo tutti $i$ giorni, che formiamo stando insieme." E conclude: "Due modi ci sono per non soffrirne. Il primo riesce facile a molti:accettare l'inferno e diventarne parte fino al punto di non vederlo più. Il secondo è rischioso ed esige attenzione e apprendimento continui: cercare e saper riconoscere chi e che cosa, in mezzo all'inferno, non è inferno, e farlo durare, e dargli spazio."

Ecco,Totem potrebbe essere riassunto come un tentativo di radunare le persone per sentire storie narrate ad alta voce. Arte, letteratura, musica e gente, tutto ciò che non rappresenta inferno e farli rimanere, durare... 


\section{Entrevista com Alessandro Baricco}

\section{SESC- Pinheiros- São Paulo- SP}

20- maio- 2006

1) Em Novecento, nos parece que, ainda que dentro dos limites, "da proa a popa" do navio, aquele pianista era muito mais livre do que nós, que vivemos nesta verdadeira "prisão a céu aberto" (como diz Adorno). O que é, para Novecento, a verdadeira liberdade?

$\mathrm{R}$ : Aquilo, sim, para Novecento representa a verdadeira liberdade. A liberdade, para ele, é poder descobrir tudo aquilo que se está à altura de descobrir, dentro de um limite. Isto é ser livre. Se o limite não existe, ele diz, você é Deus. Mas é uma situação que, para os humanos, é insustentável, é angustiante demais. Porém, é exatamente o que ele pensa e no que acredita.

2) Hölderlin concebia a música como símbolo da gênese do mundo. Sabe-se que, na célebre torre de Tübingen, por mais de trinta anos, numa espécie de "escurecimento" da mente, ele passou o tempo cantando. E, talvez, se possa dizer que ele assim o fez, porque a gênese de um mundo é, essencialmente, um fenômeno de ressonância.

Não seria algo semelhante àquilo em que acreditava o personagem Pekisch de Castelli di Rabbia, criando o "humanófono", uma espécie de teclado humano, em que as teclas eram os homens e suas respectivas vozes?

R: Deixe-me pensar... Ele é um homem que vive no universo musical. Dentro daquele universo, ele procura a origem, isto é, um ponto, um único ponto, em que haja o sentido de tudo; daí porque o "humanófono".

Mas, assim como ele o procura na música, há o outro personagem que o procura nos vidros; outro, ainda, nos trens. Pekisch procura aquele ponto originário (sim, em certa medida, a gênese do mundo), no qual o sentido está naquele universo, que é o universo dos sons.

3) O que é, para você, a Literatura? Como é a sua relação com de escrever? O seu trabalho seria fruto de digamos, $90 \%$ de transpiração?

R: Digamos que é como um trabalho artesanal muito cansativo, exigente, porém genial. Assim, é um cansaço que suporto muito bem e não é algo que eu faça todos os dias, porque não sou um habitué. É um trabalho, para mim, muito emocionante: o que eu mais gosto de fazer é escrever. Ao contrário, gosto menos de publicar.

4) Em Oceano Mare, o nome "Estalagem Almayer", local em que se passa quase toda a história é uma paródia, uma espécie de homenagem a J. Conrad, autor de A loucura do Almayer? 
R: Sim, verdadeiramente, admiro muitíssimo J. Conrad. Sim, é uma homenagem.

5) Calvino afirma no livro "Seis propostas para o próximo milênio" que o seu "interesse pela fábula é muito mais um interesse estilístico e estrutural, pela economia, o ritmo, a lógica essencial com que são contadas." O que você pensa desse universo fabular?

$\mathrm{R}$ : Eu, particularmente, não gosto das fábulas. Tenho este defeito. Não amo as fábulas. Não as amava, nem mesmo quando era реqиепо...

6) Segundo Kierkegaard "um sistema é um castelo de gigantes, onde o indivíduo não tem lugar." Novecento, Bartleboom, Mormy, Ultimo Parri, aqueles personagens de seus livros que tinham a "sombra de ouro", porque criaturas muito especiais, tiveram que morrer porque jamais teriam se adequado ao sistema?

R: Sim, de certa maneira, sim. Porém, cada um deles, encontra um modo de ser feliz. Ou seja, mesmo, aparentemente "inadequados" ao sistema, não são pessoas infelizes. É Novecento quem diz: "Não somos loucos, quando encontramos um modo de nos salvar". Então, esses personagens eram felizes, apesar do sistema. Eram maiores do que ele.

7) Em Castelli di Rabbia, as epígrafes que abrem cada capítulo são de Rilke. Você poderia comentar essa sua escolha?

R: Trata-se da Oitava Elegia Duinese de Rilke. Eu gosto muito de Rilke! Penso que aquelas epígrafes são as epígrafes justas para aquele livro.

8) Em Questa Storia, seu último romance, há uma personagem, Elizaveta, que gosta de escrever diários. Porém, o primeiro diário que escreve representa uma "mentira". O que pode significar um diário "mentiroso"?

R: $O$ diário de Elizaveta é falso, sim. Porque pode acontecer que alguém escreva um diário falso. Há muitas pessoas que o fazem, por exemplo aqueles que, hoje, escrevem os blogs, na Internet. Para mim, aquilo é apenas um modo de contar.

9) Em Oceano Mare, existem diversas crianças: Dood, Ditz, Dol, Dira, etc... São como as crianças que vivem dentro de cada um de nós? Aquelas, capazes de nos fazer ver aquilo que nosso olhar, muito condicionado, já não consegue mais?

R: Não sei... De certo modo, todos são anjos... 
10) Nas suas obras, parece-nos que você procura, um pouco à la Benjamin, a precisão do movimento e ao mesmo tempo a elegância da poesia. E há, também, alguns críticos como La Porta, que o definem como um escritor pós-moderno. Como você se definiria? Você seria uma espécie de "escritor benjaminiano pós-moderno"?

R: Benjaminiano, sim!! Porém, "pós-moderno" é uma maneira simplista de compreender as coisas.

Eu acho que não há ninguém que consiga compreender o que eu faço, nem eu теsmo

11) Como é a sua relação com o cinema?

R: É fortíssima. De fato, os meus livros são muito, por assim dizer, "cinematográficos". E há aqueles que não gostam dos meus livros, exatamente, por isso.

12) Os "justos", segundo Benjamin, são os verdadeiros “ porta-vozes da criatura”. São aqueles que, como Bartleboom (de Oceano Mare) "não tem a panca de herói, mas, no fundo, seguram o rojão." Em diversos de seus livros, aparecem personagens deste tipo. Você poderia comentá-los?

R: Segundo Benjamin, a narração provem de duas fontes:

a) do mercador, aquele que viaja e que é capaz de ludibriar os outros, de trapacear

b) do camponês, o homem honesto, que não sai de seu pequeno lugar

Nós carregamos, em nós, os dois, o santo e o trapaceiro: o justo (o camponês) e o mercador (aquele que nos induz a comprar); a madona e a puta. Se nos faltasse um desses traços, a arte de narrar não se completaria. Ao pensarmos nos narradores orais, percebemos que eles têm esses dois traços muito evidentes. E podemos, também dizer, partindo, ainda, de Benjamin, que existem dois tipos de narradoresescritores:

a) os que se parecem com Proust- o justo

b) os que se parecem com Melville ou Conrad-o mercador, o viajante

Logicamente, existem muitos híbridos, muitos meio-termo. Eu me considero um tipo que se agita muito quando escreve. Ao contrário, por exemplo, Kafka é quase imóvel (ele confia na força das suas palavras).

Hoje, tudo é muito difícil. São poucos os que têm o perfil do camponês. Até mesmo porque a técnica se tornou muito sofisticada e o público dos livros é bastante exigente.

Os meus personagens, que simbolizam os "justos", talvez representem algo com o que mantenho uma forte identidade. Acho que entre o mercador e o camponês, eu sou mais o segundo... 
13) "Contar uma história", "Dizer o mar", "Dar voz àqueles que voltam emudecidos da guerra", são questões que cabem ao escritor?

R: Segundo o que eu penso, sim. Estes são, em essência, alguns dos eixos, pelos quais busco compreender qual seja a missão de um escritor. Logicamente, há muitos que não pensam da mesma forma que eu...

14) Você acredita no narrador como uma espécie de artesão. Em termos literários, como isso se concretiza?

R: Bem, eu costumo pedir, a meus alunos, (brincando, logicamente) lá na Holden, que bordem, em seus travesseiros, o que Valèry, retomado por Benjamin, ensina sobre a arte de narrar. Narrar, segundo ele, é trabalhar como um artesão, conjugando, ao mesmo tempo, olho, mão e alma, sobre a matéria da experiência, de um modo útil, sólido e singular.

O que quer dizer que, para escrever bem devemos, primeiramente, prestar atenção ao olhar dos artesãos. Perceber como eles olham. Se alguém deixa de olhar, com cuidado e detalhe tudo se torna inútil.

Também, a mão, é fundamental, no trabalho de um artesão. Para o escritor, isso seria correspondente à técnicalcom a mão, tudo fica mais físico). Se pensarmos em um marceneiro, por exemplo, ele deve trazer, nas mãos, a precisão e o movimento necessários para aparar a madeira e retirar os excessos. Então, olho e mão, para quem escreve, são como a técnica e o olhar minucioso do artesão. Mas, nem o olho, nem a mão podem se mover sem a alma. E como definir a alma? Talvez, como o que dizia Louis Armstrong, a propósito do jazz. Se você tiver necessidade de perguntar o que é o jazz, a única certeza é a de que não haverá jamais uma resposta à sua pergunta...

15) Você poderia comentar a experiência de Totem?

R: O primeiro capítulo de meu livro Balene e sogni, em que eu e meus companheiros tentamos contar o que significou Totem, contem uma citação, extraída da obra de Calvino, Cidades Invisiveis. Marco Polo responde a Kublai Kan, a respeito do que seria o Inferno: "O inferno dos vivos não é algo que será: se existe, é aquele que já está aqui, o inferno no qual vivemos todos os dias, que formamos estando juntos. Existem duas maneiras de não sofrer. A primeira é fácil para a maioria das pessoas: aceitar o inferno e tornar-se parte dele, até o ponto de não percebê-lo. A segunda é arriscada e exige atenção e aprendizagem contínuas: 
tentar saber reconhecer quem e o quê, no meio do inferno, não é inferno, e preservá-lo, e abrir espaço."

Pois bem, Totem foi uma tentativa de reunir pessoas para ouvir histórias, narradas em voz alta. Arte, literatura, música e gente, tudo que não representa inferno e fazê-los permanecer, durar...

${ }^{47}$ BARICCO, A.; TARASCO, G. Balene e sogni. Leggere e ascoltare. L'esperienza di Totem. Torino: Einaudi, 2003, p.5. 